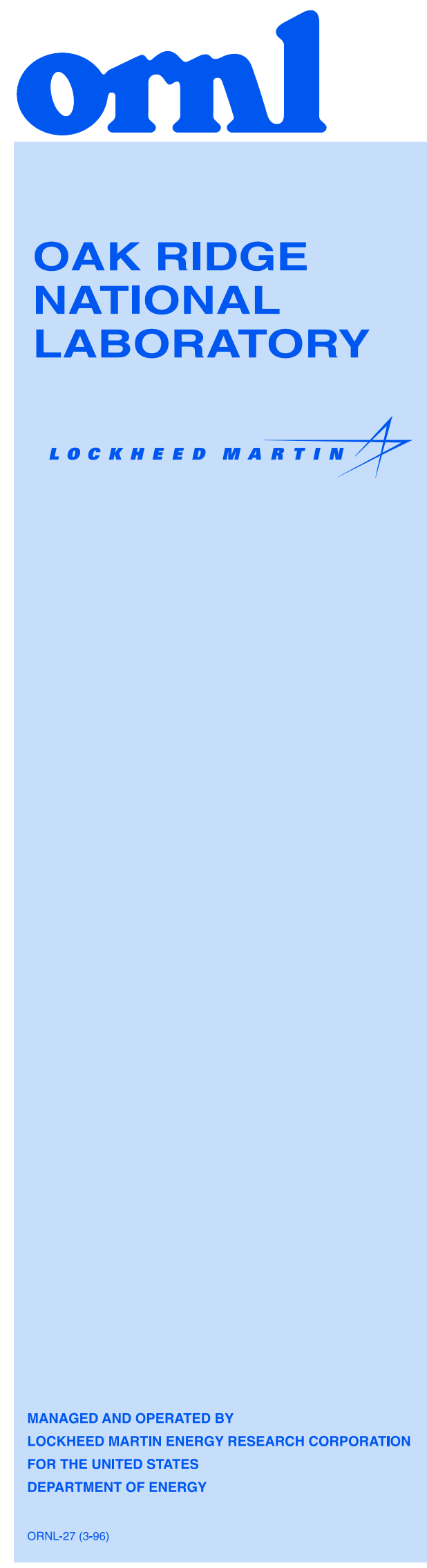

\title{
Preliminary Calculational Analysis of the Actinide Samples from FP-4 Exposed in the Dounreay Prototype Fast Reactor
}

\author{
B. D. Murphy \\ T. D. Newton \\ S. Raman
}


This report has been reproduced directly from the best available copy.

Available to DOE and DOE contractors from the Office of Scientific and Technical Information, P.O. Box 62, Oak Ridge, TN 37831; prices available from (615) 576-8401.

Available to the public from the National Technical Information Service, U.S. Department of Commerce, 5285 Port Royal Rd., Springfield, VA 22161.

This report was prepared as an account of work sponsored by an agency of the United States Government. Neither the United States nor any agency thereof, nor any of their employees, makes any warranty, express or implied, or assumes any legal liability or responsibility for the accuracy, completeness, or usefulness of any information, apparatus, product, or process disclosed, or represents that its use would not infringe privately owned rights. Reference herein to any specific commercial product, process, or service by trade name, trademark, manufacturer, or otherwise, does not necessarily constitute or imply its endorsement, recommendation, or favoring by the United States Government or any agency thereof. The views and opinions of authors expressed herein do not necessarily state or reflect those of the United States Government or any agency thereof. 
ORNL-6889

\title{
PRELIMINARY CALCULATIONAL ANALYSIS OF THE ACTINIDE SAMPLES FROM FP-4 EXPOSED IN THE DOUNREAY PROTOTYPE FAST REACTOR
}

\author{
B. D. Murphy, ${ }^{*}$ T. D. Newton, ${ }^{* *}$ and S. Raman ${ }^{\dagger}$
}

Date Completed: December 1996

Date Published: December 1996

${ }^{*}$ Computational Physics and Engineering Division.

**AEA Technology plc. Winfrith, United Kingdom.

'Physics Division.

\author{
Prepared by the \\ OAK RIDGE NATIONAL LABORATORY \\ managed by \\ LOCKHEED MARTIN ENERGY RESEARCH CORP. \\ for the \\ U.S. DEPARTMENT OF ENERGY \\ under contract DE-AC05-96OR22464
}




\section{CONTENTS}

Page

LIST OF FIGURES

LIST OF TABLES

ACKNOWLEDGMENTS

EXECUTIVE SUMMARY

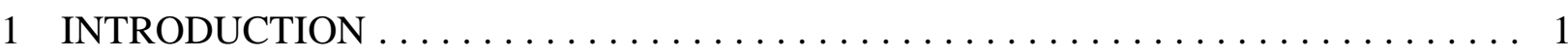

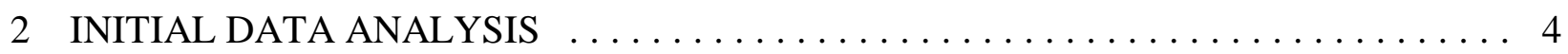

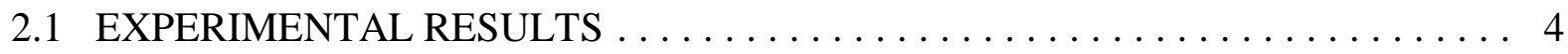

2.2 SIMULATION OF THE ACTINIDE IRRADIATION $\ldots \ldots \ldots \ldots \ldots \ldots \ldots .4$

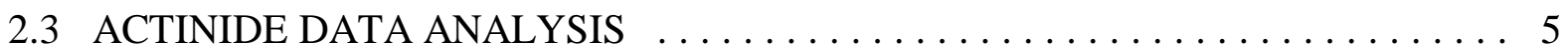

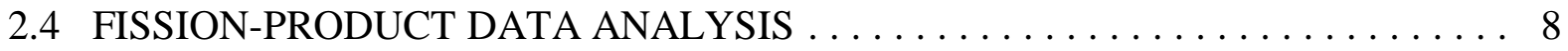

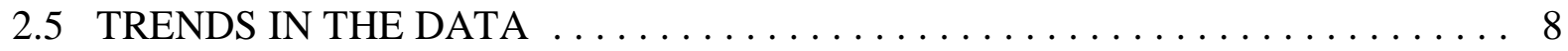

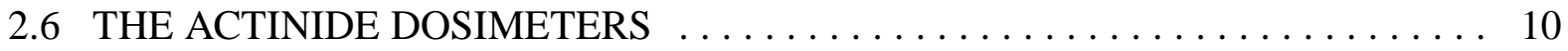

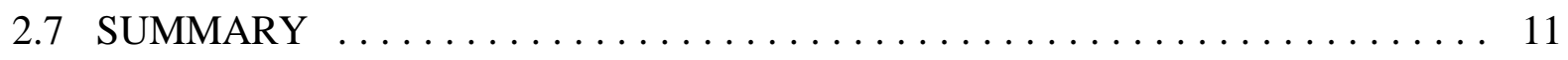

$3 \quad$ FURTHER ANALYSIS AND CORRECTIONS $\ldots \ldots \ldots \ldots \ldots \ldots \ldots \ldots \ldots \ldots, 12$

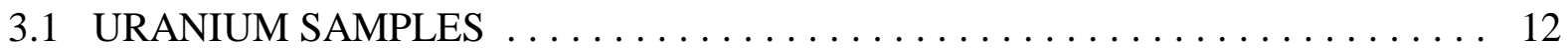

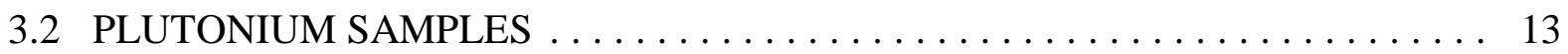

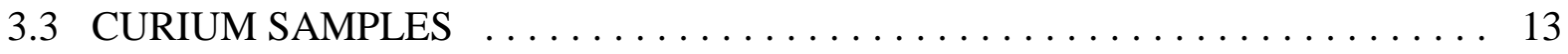

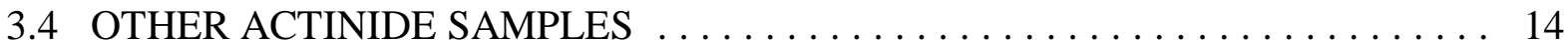

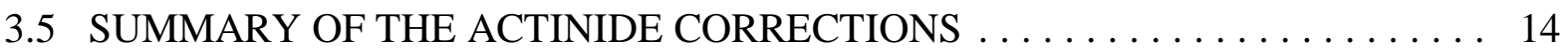

3.6
COPPER AND COBALT DOSIMETERS $\ldots \ldots \ldots \ldots \ldots \ldots \ldots \ldots \ldots \ldots \ldots$

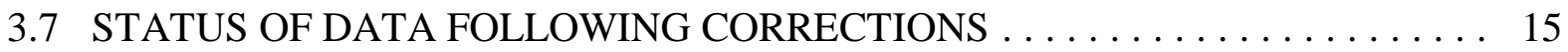

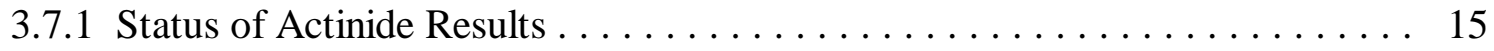

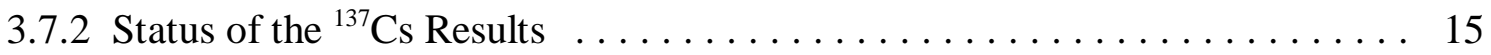

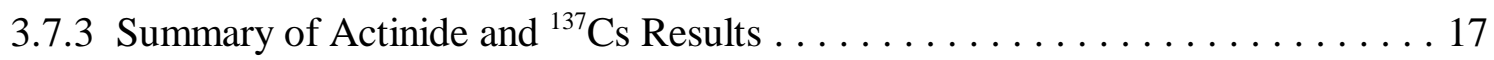

4 ACTINIDE DEPLETION AND IRRADIATION-PRODUCT RESULTS $\ldots \ldots \ldots \ldots 21$

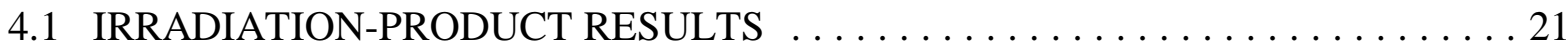

4.2 DEPLETION OF IRRADIATED ACTINIDES $\ldots \ldots \ldots \ldots \ldots \ldots \ldots \ldots \ldots \ldots 27$

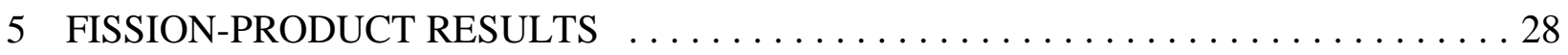

$5.1 \quad$ SUMMARY OF FISSION-PRODUCT RESULTS $\ldots \ldots \ldots \ldots \ldots \ldots \ldots \ldots 28$

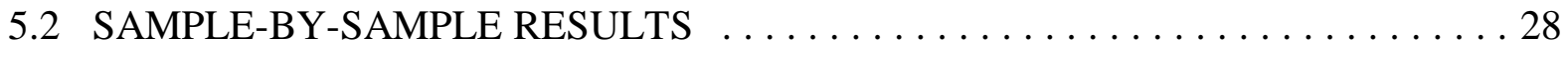

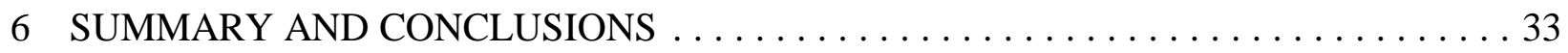

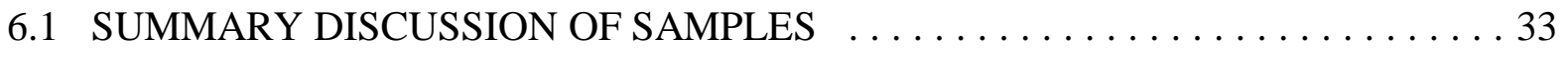




\section{CONTENTS (continued)}

$\underline{\text { Page }}$

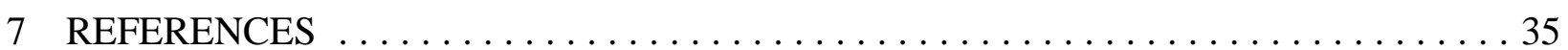

APPENDIX A. NUCLIDES IN THE LAW LIBRARY . . . . . . . . . . . . . . . 37

APPENDIX B. UNCERTAINTY IN MEASURED ACTINIDE CONCENTRATIONS . . . . 47

APPENDIX C. ONE-GROUP CROSS SECTIONS $\ldots \ldots \ldots \ldots \ldots \ldots \ldots \ldots \ldots \ldots \ldots$. $\ldots \ldots$

APPENDIX D. DETAILED SUMMARY OF ACTINIDE RESULTS $\ldots \ldots \ldots \ldots \ldots \ldots 53$

APPENDIX E. DETAILED SUMMARY OF FISSION-PRODUCT

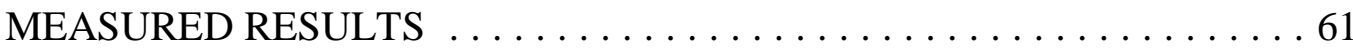

APPENDIX F. SUMMARY OF EXPERIMENTAL AND CALCULATED FISSION-

PRODUCT VALUES FOR ACTINIDE SAMPLES . . . . . . . . . . 65 


\section{LIST OF FIGURES}

$\underline{\text { Figure }}$

$\underline{\text { Page }}$

$1 \quad$ E/C ratio for the primary actinide concentration following initial analysis of

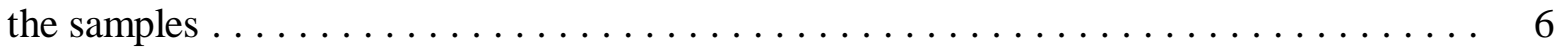

$2 \quad$ E/C values for the nine analyzed fission products in the case of three plutonium samples . 9

$3 \quad$ E/C values for the ${ }^{137} \mathrm{Cs}$ concentration in the actinide samples following initial analysis $\ldots \quad 9$

$4 \quad$ The $\mathrm{E} / \mathrm{C}$ values for the ${ }^{137} \mathrm{Cs}$ concentration in the samples versus the $\mathrm{E} / \mathrm{C}$ values

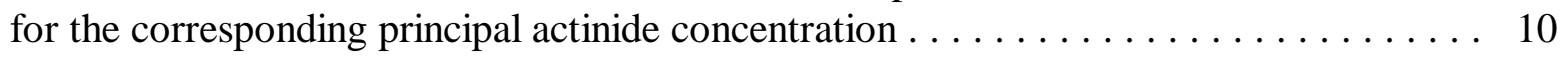

$5 \quad$ Adjusted E/C values for the primary actinide concentrations following correction . . . . . 19

6 Adjusted E/C values for the ${ }^{137} \mathrm{Cs}$ concentration in the actinide samples following

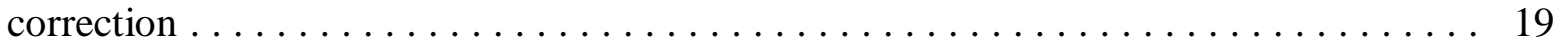

$7 \quad$ The $\mathrm{E} / \mathrm{C}$ values for the ${ }^{137} \mathrm{Cs}$ concentration in the samples versus the $\mathrm{E} / \mathrm{C}$ values for the corresponding principal actinide concentration, following correction . . . . . . . 20

$8 \quad$ The ${ }^{137} \mathrm{Cs}$ fission yields from ENDF/B-VI for the actinides of interest . . . . . . . . . . 29

$9 \quad$ E/C ratio for the ${ }^{125} \mathrm{Sb}$ concentration in the actinide samples $\ldots \ldots \ldots \ldots \ldots$

$10 \quad \mathrm{E} / \mathrm{C}$ values for the ${ }^{134} \mathrm{Cs}$ concentration in the actinide samples $\ldots \ldots \ldots \ldots \ldots \ldots$

$11 \quad \mathrm{E} / \mathrm{C}$ values for the ${ }^{137} \mathrm{Cs}$ concentration in the actinide samples $\ldots \ldots \ldots \ldots \ldots$

$12 \quad$ E/C values for the ${ }^{144} \mathrm{Ce}$ concentration in the actinide samples . . . . . . . . . . . 31

$13 \quad \mathrm{E} / \mathrm{C}$ values for the ${ }^{152} \mathrm{Eu}$ concentration in the actinide samples $\ldots \ldots \ldots \ldots \ldots$. . . .

$14 \quad \mathrm{E} / \mathrm{C}$ values for the ${ }^{154} \mathrm{Eu}$ concentration in the actinide samples $\ldots \ldots \ldots \ldots \ldots$

$15 \quad \mathrm{E} / \mathrm{C}$ values for the ${ }^{155} \mathrm{Eu}$ concentration in the actinide samples . . . . . . . . . . 32

B.1 E/C ratio for the amount of a sample that is burned versus the measured

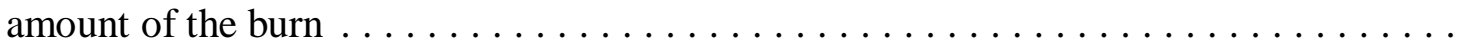

C.1 One-group actinide fission cross sections calculated for the PFR using both U.S. and U.K. cross-section data

C.2 One-group actinide capture cross sections calculated for the PFR using both U.S.

and U.K. cross-section data 


\section{LIST OF TABLES}

Table

Page

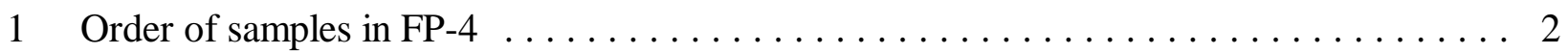

$2 \quad$ Summary of initial data analysis on principal actinides $\ldots \ldots \ldots \ldots \ldots \ldots$

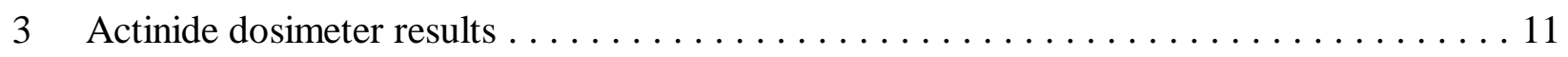

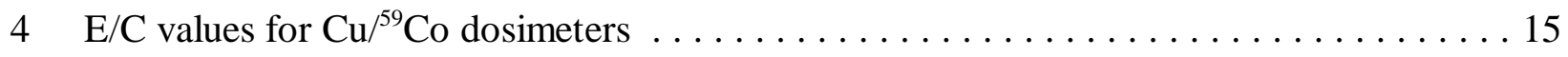

5 A comparison of principal actinide $\mathrm{E} / \mathrm{C}$ values following correction $\ldots \ldots \ldots \ldots$

$6 \quad$ A comparison of ${ }^{137} \mathrm{Cs} \mathrm{E} / \mathrm{C}$ values following correction $\ldots \ldots \ldots \ldots \ldots \ldots$

$7 \quad$ Summary of principal actinide results following adjustment (nondosimeter samples) . . . . 22

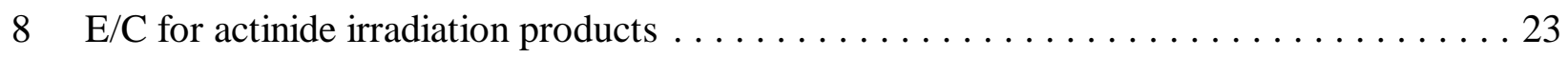

$9 \quad \mathrm{E} / \mathrm{C}$ for change in concentration of irradiated actinides $\ldots \ldots \ldots \ldots \ldots \ldots \ldots$

A.1 Contents of 238 -group LAW library $\ldots \ldots \ldots \ldots \ldots \ldots \ldots \ldots \ldots \ldots \ldots$

B.1 Cases involving two samples of an actinide $\ldots \ldots \ldots \ldots \ldots \ldots \ldots \ldots \ldots$

D.1 Actinide composition of sample capsules $\ldots \ldots \ldots \ldots \ldots \ldots \ldots \ldots \ldots \ldots \ldots \ldots$. $\ldots \ldots \ldots$.

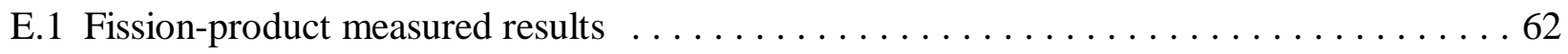

F.1 Comparison of measured and calculated values for fission products $\ldots \ldots \ldots 6$ 


\section{ACKNOWLEDGMENTS}

We thank P. B. Hemmig (U.S. Department of Energy), K. M. Swanson and C. Brown (United Kingdom Atomic Energy Authority), T. Mukaiyama (Japan Atomic Energy Research Institute), and J. B. Ball (Oak Ridge National Laboratory) for their interest in this work and their cooperation and tangible support. This report was read critically by R. Q. Wright of Oak Ridge National Laboratory. 


\section{EXECUTIVE SUMMARY}

This report discusses the current status of results from an extensive experiment on the irradiation of selected actinides in a fast reactor. These actinides ranged from thorium to curium. They were irradiated in the core of the Dounreay Prototype Fast Reactor. Rates for depletion, transmutation, and fission-product generation were experimentally measured, and, in turn, were calculated using current cross-section and fission-yield data. Much of the emphasis is on the comparison between experimental and calculated values for both actinide and fission-product concentrations. Some of the discussion touches on the adequacy of current cross-section and fissionyield data. However, the main purposes of the report are (1) to collect in one place the most recent experimental and calculated data, (2) to discuss the comparisons between the experimental and calculated results, (3) to discuss each sample that was irradiated giving details of any adjustments needed or specific problems encountered, and (4) to give a chronology of the analysis as it pertained to the set of samples (referred to as FP-4 samples) that constitutes the most extensively irradiated and final set.

The results and trends reported here, together with those discussions touching on current knowledge about cross sections and fission yields, are intended to serve as a starting point for further analysis. In general, these results are encouraging with regard to the adequacy of much of the currently available nuclear data in this region of the periodic table. But there are some cases where adjustments and improvements can be suggested. However, the application of these results in consolidating current cross-section and fission-yield data must await further analysis. 


\section{INTRODUCTION}

Since 1979, a cooperative agreement has been in effect between the United States and the United Kingdom to investigate actinide burning in fast reactors. As a result, actinide samples in the 1- to 20-mg range have been irradiated in the Dounreay Prototype Fast Reactor (PFR). Isotopes of thorium, protactinium, uranium, neptunium, plutonium, americium, and curium were encapsulated in three PFR fuel pins. Two of the fuel pins (FP-1 and FP-2) were exposed to 63 effective full-power days (EFPD) of reactor operation. The data from these were used in preparatory studies at Oak Ridge National Laboratory (ORNL). Another fuel pin (FP-3) was exposed and sent to the Atomic Energy Research Establishment (AERE), Harwell, for analysis. A fourth fuel pin (FP-4) was also assigned to ORNL for analysis. This fourth fuel pin was exposed for 492 EFPD. The analysis of FP-4 is described in this report.

Fuel pin 4 (FP-4) was composed of 26 experimental capsules, or samples, together with nine dosimeter capsules. Each of the 26 experimental capsules, or samples, contained a primary actinide to be irradiated. And, of course, besides the primary actinide, the capsules, in general, contained smaller concentrations of other isotopic species; however, each sample can be identified with one primary or predominant actinide species. As noted above, the actinides ranged from thorium to curium, and five nuclides $\left({ }^{240} \mathrm{Pu},{ }^{241} \mathrm{Am},{ }^{243} \mathrm{Am},{ }^{244} \mathrm{Cm}\right.$, and $\left.{ }^{246} \mathrm{Cm}\right)$ had two capsules each. Thus FP-4 contained 21 individual actinide species as follows:

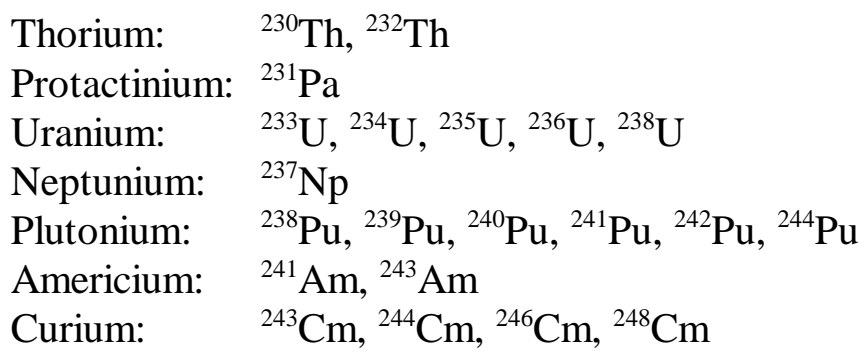

There were three sets of dosimeter capsules. A set was placed at each end of the fuel pin, and the third set was placed in the middle of the pin. Each dosimeter set consisted of a ${ }^{235} \mathrm{U} /{ }^{238} \mathrm{U}$ dosimeter, $\mathrm{a}^{237} \mathrm{~Np} /{ }^{239} \mathrm{Pu}$ dosimeter, and a $\mathrm{Cu} /{ }^{59} \mathrm{Co}$ dosimeter. Table 1 is a listing of the sample numbers and the primary nuclides that they contain. In the table they are listed in the order in which they were positioned in the fuel pin. Some of the samples suffered partial or total loss during handling or chemical analysis. The notes in Table 1 indicate losses that are known or suspected. In some instances it was possible to recover from the results of these losses; in some instances it was not.

During the irradiation experiment, FP-4 was located such that it straddled the core centerline of the PFR. The core extended $45.72 \mathrm{~cm}$ above and below the centerline (i.e., a total core height of $91.44 \mathrm{~cm}$ ). The experimental region of FP-4 containing the 35 capsules was $36.83 \mathrm{~cm}$ in length. Thus the experimental capsules were confined to the middle third of the reactor core, and one would therefore not expect to encounter uncertainties due to edge effects in the estimation of neutron flux and spectra. One should, however, be cognizant of the possible effects of the control rods that enter the core from the top. Dounreay estimates give about a $2 \%$ effect on the neutron flux in the center 
Table 1. Order of samples in FP-4

\begin{tabular}{|c|c|c|}
\hline $\begin{array}{c}\text { Sample } \\
\text { No. }\end{array}$ & $\begin{array}{l}\text { Principal } \\
\text { nuclide(s) }\end{array}$ & Notes \\
\hline 1 & ${ }^{235} \mathrm{U} /{ }^{238} \mathrm{U}(\mathrm{dos})$ & \\
\hline 2 & ${ }^{237} \mathrm{~Np} /{ }^{239} \mathrm{Pu}(\mathrm{dos})$ & \\
\hline 3 & $\mathrm{Cu} /{ }^{59} \mathrm{Co}(\mathrm{dos})$ & \\
\hline 4 & ${ }^{248} \mathrm{Cm}$ & \\
\hline 5 & ${ }^{246} \mathrm{Cm}$ & \\
\hline 6 & ${ }^{246} \mathrm{Cm}$ & \\
\hline 7 & ${ }^{237} \mathrm{~Np}$ & \\
\hline 8 & ${ }^{244} \mathrm{Cm}$ & Lost during removal from fuel pin \\
\hline 9 & ${ }^{244} \mathrm{Cm}$ & \\
\hline 10 & ${ }^{243} \mathrm{Cm}$ & \\
\hline 11 & ${ }^{238} \mathrm{U}$ & Portion lost in dissolution \\
\hline 12 & ${ }^{243} \mathrm{Am}$ & \\
\hline 13 & ${ }^{243} \mathrm{Am}$ & \\
\hline 14 & ${ }^{241} \mathrm{Am}$ & \\
\hline 15 & ${ }^{241} \mathrm{Am}$ & \\
\hline 16 & ${ }^{242} \mathrm{Pu}$ & Significant sample loss is suspected \\
\hline 17 & ${ }^{235} \mathrm{U} /{ }^{238} \mathrm{U}(\mathrm{dos})$ & \\
\hline 18 & ${ }^{237} \mathrm{~Np} /{ }^{239} \mathrm{Pu}(\mathrm{dos})$ & \\
\hline 19 & $\mathrm{Cu} /{ }^{59} \mathrm{Co}(\mathrm{dos})$ & \\
\hline 20 & ${ }^{244} \mathrm{Pu}$ & \\
\hline 21 & ${ }^{240} \mathrm{Pu}$ & \\
\hline 22 & ${ }^{240} \mathrm{Pu}$ & \\
\hline 23 & ${ }^{239} \mathrm{Pu}$ & Portion lost in dissolution \\
\hline 24 & ${ }^{241} \mathrm{Pu}$ & \\
\hline 25 & ${ }^{232} \mathrm{Th}$ & \\
\hline 26 & ${ }^{236} \mathrm{U}$ & Significant sample loss is suspected \\
\hline 27 & ${ }^{234} \mathrm{U}$ & \\
\hline 28 & ${ }^{235} \mathrm{U}$ & \\
\hline 29 & ${ }^{231} \mathrm{~Pa}$ & \\
\hline 30 & ${ }^{238} \mathrm{Pu}$ & Portion lost in dissolution. Data abandoned \\
\hline 31 & ${ }^{230} \mathrm{Th}$ & \\
\hline 32 & ${ }^{233} \mathrm{U}$ & Portion lost in dissolution. Data abandoned \\
\hline 33 & ${ }^{235} \mathrm{U} /{ }^{238} \mathrm{U}(\mathrm{dos})$ & Lost in handling \\
\hline 34 & ${ }^{237} \mathrm{~Np} /{ }^{239} \mathrm{Pu}(\mathrm{dos})$ & \\
\hline 35 & $\mathrm{Cu} /{ }^{59} \mathrm{Co}(\mathrm{dos})$ & \\
\hline
\end{tabular}


third of the core from the control rods during the course of a reactor cycle. Pin FP-4 was oriented such that capsule \#1 was towards the top of the core (i.e., nearer to the control rods).

Regarding the individual capsules, there were $35 \mathrm{of}$ them spanning a length of $36.83 \mathrm{~cm}$. The capsules were fabricated from vanadium, and they were $0.763 \mathrm{~cm}$ in length and $0.152 \mathrm{~cm}$ in diameter. The enclosed volume in each capsule was $5.231 \times 10^{-3} \mathrm{cc}$. The actinide materials to be irradiated were in the form of oxide powders and were placed in the capsules and sealed. It would not have been practical to remove the sample material following irradiation. Rather, each sample consisting of the vanadium and the enclosed material was dissolved in nitric acid prior to radiochemical analysis. Laboratory samples used to determine actinide and fission-product concentrations were then obtained from the resulting solution. 


\section{INITIAL DATA ANALYSIS}

In this section we report on the initial results from a comparison of experimental and calculated values from the PFR irradiation of the FP-4 samples. The next section will report on more detailed subsequent comparisons where an effort was also made to correct for some experimental problems encountered in the early analysis.

\subsection{EXPERIMENTAL RESULTS}

The report by Walker et al. ${ }^{1}$ describes the laboratory analysis of the actinides and fission products contained in the FP-4 samples. All samples, including in each case the vanadium capsule, were dissolved in nitric acid following irradiation, and all radiochemical analyses were performed on the dissolved solution. Measurements were carried out for all primary actinides and for various other actinide species following irradiation. Besides measuring the concentration of the primary actinide, the relative abundances of other isotopes present were also obtained. A variety of other actinides produced via neutron capture and alpha and beta decay were analyzed. The variety of actinides analyzed varied from sample to sample and will be discussed in more detail as we report on the individual samples. Experimental data were also obtained on a number of long-lived fission products. The fission products analyzed were ${ }^{106} \mathrm{Ru},{ }^{110 \mathrm{~m}} \mathrm{Ag},{ }^{125} \mathrm{Sb},{ }^{134} \mathrm{Cs},{ }^{137} \mathrm{Cs},{ }^{144} \mathrm{Ce},{ }^{152} \mathrm{Eu},{ }^{154} \mathrm{Eu}$, and ${ }^{155} \mathrm{Eu}$.

Seven of the exposed actinide samples and one dosimeter are listed in Table 1 as having suffered either partial or total loss (or where loss was suspected). For two of these, the ${ }^{238} \mathrm{U}$ sample (11) and the ${ }^{239} \mathrm{Pu}$ sample (23), the losses could be estimated and useful data were obtained. For four capsules, the ${ }^{244} \mathrm{Cm}$ sample (8), the ${ }^{238} \mathrm{Pu}$ sample (30), the ${ }^{233} \mathrm{U}$ sample (32), and the ${ }^{235} \mathrm{U} /{ }^{238} \mathrm{U}$ sample dosimeter (33), no useful data could ever be recovered. For the final two of the questionable samples, the ${ }^{242} \mathrm{Pu}$ sample (16) and the ${ }^{236} \mathrm{U}$ sample (26), a correction was also effected, although in the early stages of analysis it was not realized that there was a problem with these two samples.

\subsection{SIMULATION OF THE ACTINIDE IRRADIATION}

The purpose of this work was to compare the results of this irradiation experiment with current knowledge of cross sections, decay rates, and fission yields. Thus a major part of the effort involved the simulation of the experiment using currently available nuclear data. The simulations were carried out with the ORIGEN-S code ${ }^{2}$ together with the cross-section data from ENDF/B-V ${ }^{3}$ supplemented by fission-product yield data from ENDF/B-VI. ${ }^{4}$ Detailed power-history data were obtained from the Dounreay Nuclear Power Development Establishment, and these are described in another report by Raman et al. ${ }^{5}$ The length of irradiation and flux levels were such that the samples in FP-4 were exposed to a fluence that was on the order of $2 \times 10^{23} \mathrm{n} / \mathrm{cm}^{2}$.

The ORIGEN-S code used for these simulations required one-group cross sections. Thus a significant preliminary effort in the simulation process involved the development of one-group cross sections based on the PFR neutron flux data. The PFR neutron spectrum peaks in the 200-keV 
region, and for more details one should refer to the power history report. ${ }^{5}$ The PFR irradiation of the FP-4 samples can be conveniently divided into 10 reactor runs covering 492 EFPD. The fuel pins previously studied (FP-1 and FP-2) were subjected to 63 EFPD of irradiation, and this corresponds to the first of these 10 reactor runs. Dounreay personnel had supplied a six-group PFR neutron spectrum for each one of these 10 runs. Thus we calculated 10 separate one-group cross-section libraries for the simulation of the full 492-EFPD irradiation.

The starting point in constructing cross-section libraries was the LAW library, as described

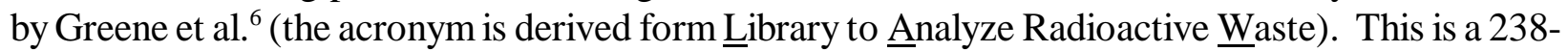
group neutron cross-section library based on ENDF/B-V data (augmented with ENDF/B-VI data for ${ }^{14} \mathrm{~N},{ }^{15} \mathrm{~N},{ }^{16} \mathrm{O},{ }^{154} \mathrm{Eu}$, and ${ }^{155} \mathrm{Eu}$ ). The LAW library contains about 300 nuclides (for a list of these nuclides, the reader is referred to Appendix A). This library was now used with each of the ten sixgroup PFR spectra to derive a cross-section library corresponding to each one of the PFR runs. In initiating this process we made use of a 37-group representative PFR spectrum that had been supplied by Dounreay at an earlier date..$^{5}$ The 37-group spectrum was boosted to 238 groups and together with the LAW library yielded a 238-group generic PFR cross-section library. This 238-group library was then collapsed to a six-group library corresponding to the six energy groups of the Dounreaysupplied spectra for the reactor runs. Using each of these ten six-group spectra in turn, a three-group library was produced for ORIGEN-S (although the ORIGEN-S calculations require one-group cross sections, the cross-section data are input to the code in terms of three energy groups-the thermal region, the resonance region, and the fast region).

Cross sections for all of the actinides of interest and for most of the fission products were contained in the LAW library. However, for a number of fission products that might be of neutronic importance, cross sections were obtained from an ORIGEN-S library prepared for a LMFBR. The latter were three-group cross sections and were added to the PFR libraries at this stage, but note that they were for the LMFBR. The LAW library contains data that come from ENDF/B-V. The LMFBR library contained data on many more nuclides (perhaps as many as 1000 in total) for which some data exist but that are not necessarily of the caliber of ENDF data. The LMFBR library is described in the original ORIGEN publication, ${ }^{7}$ and later modifications are described by Morrison, Weisbin, and Kee. ${ }^{8}$

At this stage, the theoretical yields for the fission products (from most of the actinides contained in the FP-4 samples) were updated to their ENDF/B-VI values. Furthermore, the following substitutions were made for fast-fission yields that were not available: for ${ }^{230} \mathrm{Th}$, the yields for ${ }^{232} \mathrm{Th}$ were used; for ${ }^{244} \mathrm{Pu}$, the yields for ${ }^{242} \mathrm{Pu}$ were used; and for ${ }^{242} \mathrm{Am}$ and ${ }^{242 \mathrm{~m}} \mathrm{Am}$, the yields for ${ }^{241} \mathrm{Am}$ were used.

\subsection{ACTINIDE DATA ANALYSIS}

Depending on the primary actinide and those secondary actinides that may have been present, the amount of actinide data available varied significantly from sample to sample. However, as a first step in the analysis, it is appropriate to look at the final concentration of the primary actinide in each sample and to compare measured and calculated concentrations.

Figure 1 shows the experimental-to-calculated ratios (E/C) for all primary sample actinides for which data were available at the end of irradiation (for some nuclides, data are missing because 


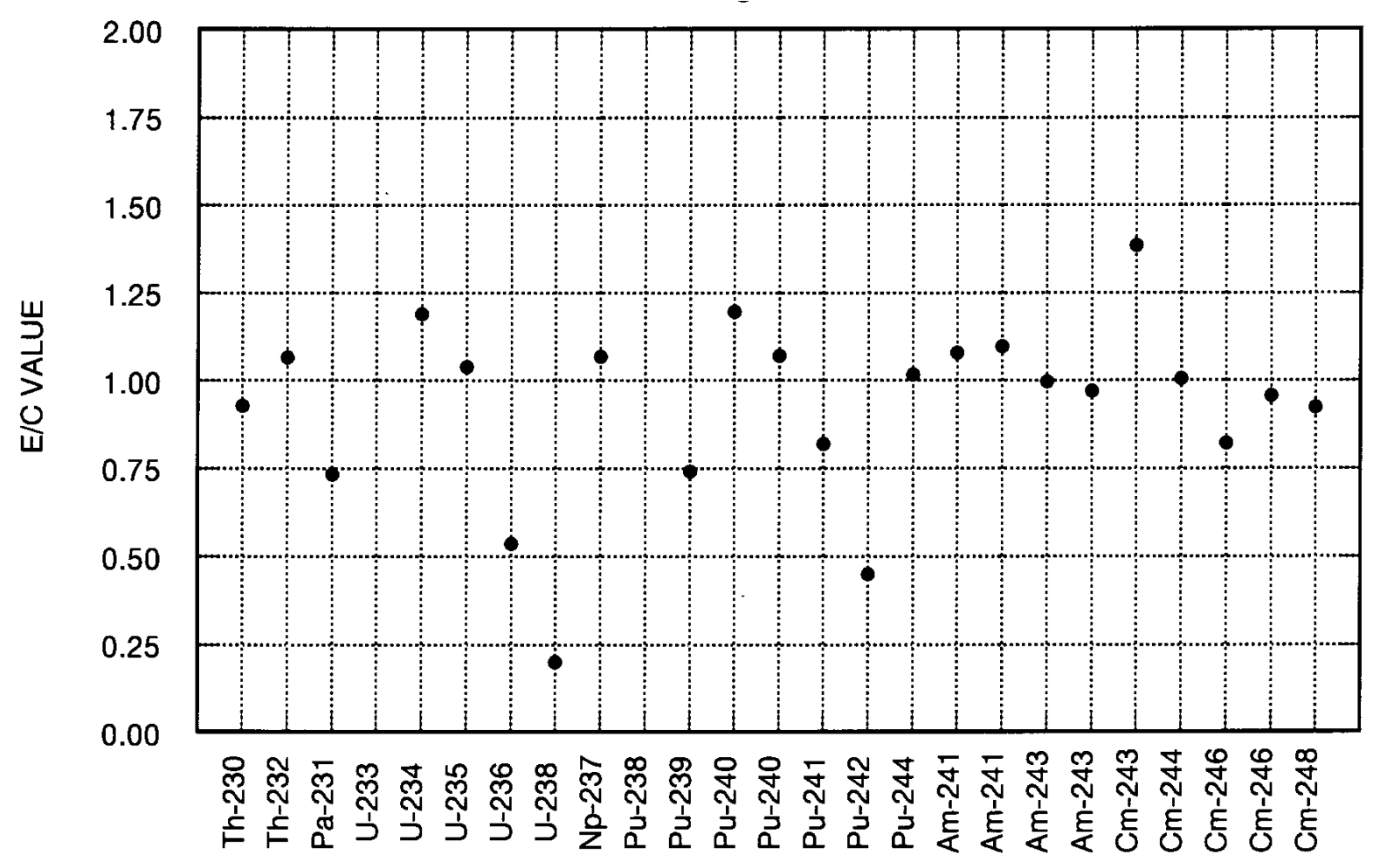

Fig. 1. E/C ratio for the primary actinide concentration following initial analysis of the samples. These values are from column 6 of Table 2 .

of partial or total sample loss). Furthermore, Fig. 1 pertains to nondosimeter samples; the dosimeters will be discussed later. By experimental we mean the value obtained in the laboratory, as reported by Walker et al.; ${ }^{1}$ by calculated we mean the value obtained using the ORIGEN-S code, together with ENDF/B-V and ENDF/B-VI and the power-history simulation of the PFR. (Later in this report we will refer to another calculation done using a PFR purpose-written code, but in this section all calculations discussed are derived from the ORIGEN-S code.) In Fig. 1, 17 samples have E/C values between 0.8 and 1.2 , or close to unity. There are five samples $-{ }^{231} \mathrm{~Pa},{ }^{236} \mathrm{U},{ }^{238} \mathrm{U}$, ${ }^{239} \mathrm{Pu}$, and ${ }^{242} \mathrm{Pu}$ - with E/C values that are noticeably below unity, and ${ }^{243} \mathrm{Cm}$ is significantly above unity. There is certainly cause to worry about the outliers; however, not all $\mathrm{E} / \mathrm{C}$ values that are close to unity for the principal actinide are necessarily indicative of good results. Where there are small cross sections, the amount of principal actinide remaining will be close to the beginning value, and if the measurements are reasonably accurate, both measured and calculated final values should be about the same irrespective of the cross-section estimates.

Table 2 is a summary of the initial data analysis on the primary actinides. It does not contain the dosimeter results which will be discussed later. Each actinide is identified by the sample number which is its position number in FP-4. In Table 2, for each primary actinide (nondosimeter samples) we show the starting amount, the ending amount, both measured and calculated, the E/C value for 
Table 2. Summary of initial data analysis on principal actinides (nondosimeter samples)

\begin{tabular}{|c|c|c|c|c|c|c|c|c|c|c|}
\hline Nuclide & $\begin{array}{c}\text { Sample } \\
\text { No. }\end{array}$ & $\begin{array}{l}\text { Starting } \\
\text { value } \\
\text { (grams) }\end{array}$ & $\begin{array}{c}\text { Ending } \\
\text { measured } \\
\text { (grams) }\end{array}$ & $\begin{array}{r}\text { Ending } \\
\text { calculated } \\
\text { (grams) }\end{array}$ & $\begin{array}{c}E / C \\
\text { at end }\end{array}$ & $\begin{array}{l}\text { E/C of } \\
\text { burn }^{b}\end{array}$ & $\begin{array}{l}\% \text { burn }^{c} \\
\text { (calc) }\end{array}$ & $\begin{array}{c}\% \text { burn }^{d} \\
\text { (meas) }\end{array}$ & \multicolumn{2}{|c|}{$\begin{array}{c}\mathrm{F}(\mathrm{n}, \mathrm{f}) \mathrm{F}(\mathrm{n},() \\
\text { one-group } \\
\text { (barns) }\end{array}$} \\
\hline Th-230 & 31 & $2.88 \mathrm{E}-3$ & $2.54 \mathrm{E}-3$ & $2.74 \mathrm{E}-3$ & 0.93 & 2.43 & 4.9 & 11.8 & 0.032 & 0.207 \\
\hline Th-232 & 25 & $1.88 \mathrm{E}-2$ & $1.81 \mathrm{E}-2$ & $1.70 \mathrm{E}-2$ & 1.07 & 0.38 & 9.6 & 3.7 & 0.011 & 0.427 \\
\hline Pa-231 & 29 & $2.51 \mathrm{E}-3$ & $9.00 \mathrm{E}-4$ & $1.23 \mathrm{E}-3$ & 0.73 & 1.26 & 51.0 & 64.2 & 0.265 & 3.067 \\
\hline $\mathrm{U}-233^{a}$ & 32 & $7.65 \mathrm{E}-3$ & - & $4.00 \mathrm{E}-3$ & - & - & 47.7 & - & 2.846 & 0.286 \\
\hline U-234 & 27 & $3.50 \mathrm{E}-3$ & $3.33 \mathrm{E}-3$ & $2.80 \mathrm{E}-3$ & 1.19 & 0.24 & 20.0 & 4.9 & 0.357 & 0.659 \\
\hline U-235 & 28 & $8.37 \mathrm{E}-3$ & $4.96 \mathrm{E}-3$ & $4.78 \mathrm{E}-3$ & 1.04 & 0.95 & 42.9 & 40.7 & 2.000 & 0.602 \\
\hline U-236 & 26 & $7.96 \mathrm{E}-3$ & $3.69 \mathrm{E}-3$ & $6.88 \mathrm{E}-3$ & 0.54 & 3.95 & 13.6 & 53.6 & 0.111 & 0.593 \\
\hline $\mathrm{U}-238^{a}$ & 11 & $9.81 \mathrm{E}-3$ & $1.75 \mathrm{E}-3$ & $8.97 \mathrm{E}-3$ & 0.20 & 9.56 & 8.6 & 82.2 & 0.045 & 0.374 \\
\hline Np-237 & 7 & $1.22 \mathrm{E}-2$ & $8.59 \mathrm{E}-3$ & $8.05 \mathrm{E}-3$ & 1.07 & 0.87 & 34.1 & 29.7 & 0.361 & 1.676 \\
\hline $\mathrm{Pu}-238^{a}$ & 30 & $3.11 \mathrm{E}-3$ & - & $1.77 \mathrm{E}-3$ & - & - & 43.1 & - & 1.224 & 0.790 \\
\hline $\mathrm{Pu}-239^{a}$ & 23 & $8.47 \mathrm{E}-3$ & $3.55 \mathrm{E}-3$ & $4.77 \mathrm{E}-3$ & 0.74 & 1.33 & 43.7 & 58.1 & 1.905 & 0.584 \\
\hline $\mathrm{Pu}-240$ & 21 & $1.08 \mathrm{E}-2$ & $1.03 \mathrm{E}-2$ & $8.57 \mathrm{E}-3$ & 1.20 & 0.26 & 20.9 & 5.4 & 0.400 & 0.621 \\
\hline $\mathrm{Pu}-240$ & 22 & $1.08 \mathrm{E}-2$ & $9.16 \mathrm{E}-3$ & $8.56 \mathrm{E}-3$ & 1.07 & 0.73 & 20.9 & 15.3 & 0.400 & 0.621 \\
\hline $\mathrm{Pu}-241$ & 24 & $4.25 \mathrm{E}-3$ & $1.13 \mathrm{E}-3$ & $1.38 \mathrm{E}-3$ & 0.82 & 1.09 & 67.5 & 73.4 & 2.622 & 0.498 \\
\hline $\mathrm{Pu}-242$ & 16 & $2.05 \mathrm{E}-3$ & $7.80 \mathrm{E}-4$ & $1.73 \mathrm{E}-3$ & 0.45 & 3.97 & 15.6 & 62.0 & 0.284 & 0.472 \\
\hline $\mathrm{Pu}-244$ & 20 & $2.11 \mathrm{E}-3$ & $1.91 \mathrm{E}-3$ & $1.88 \mathrm{E}-3$ & 1.02 & 0.87 & 10.9 & 9.5 & 0.238 & 0.269 \\
\hline Am-241 & 14 & $9.42 \mathrm{E}-3$ & $6.21 \mathrm{E}-3$ & $5.76 \mathrm{E}-3$ & 1.08 & 0.88 & 38.9 & 34.1 & 0.315 & 1.872 \\
\hline Am-241 & 15 & $9.52 \mathrm{E}-3$ & $6.36 \mathrm{E}-3$ & $5.80 \mathrm{E}-3$ & 1.10 & 0.85 & 39.1 & 33.2 & 0.315 & 1.872 \\
\hline Am-243 & 12 & $9.83 \mathrm{E}-3$ & $6.79 \mathrm{E}-3$ & $6.82 \mathrm{E}-3$ & 1.00 & 1.01 & 30.6 & 30.9 & 0.246 & 1.452 \\
\hline Am-243 & 13 & $9.80 \mathrm{E}-3$ & $6.60 \mathrm{E}-3$ & $6.77 \mathrm{E}-3$ & 0.97 & 1.06 & 30.9 & 32.7 & 0.246 & 1.452 \\
\hline Cm-243 & 10 & $3.90 \mathrm{E}-4$ & $2.20 \mathrm{E}-4$ & $1.59 \mathrm{E}-4$ & 1.38 & 0.74 & 59.2 & 43.6 & 2.844 & 0.274 \\
\hline $\mathrm{Cm}-244^{a}$ & 8 & - & - & - & - & - & - & - & 0.456 & 0.884 \\
\hline Cm-244 & 9 & $8.25 \mathrm{E}-3$ & $4.48 \mathrm{E}-3$ & $4.46 \mathrm{E}-3$ & 1.00 & 0.99 & 45.9 & 45.7 & 0.456 & 0.884 \\
\hline Cm-246 & 5 & $6.69 \mathrm{E}-3$ & $4.92 \mathrm{E}-3$ & $5.99 \mathrm{E}-3$ & 0.82 & 2.53 & 10.5 & 26.5 & 0.291 & 0.263 \\
\hline Cm-246 & 6 & $6.80 \mathrm{E}-3$ & $5.81 \mathrm{E}-3$ & $6.08 \mathrm{E}-3$ & 0.96 & 1.38 & 10.6 & 14.6 & 0.291 & 0.263 \\
\hline Cm-248 & 4 & $1.76 \mathrm{E}-3$ & $1.45 \mathrm{E}-3$ & $1.57 \mathrm{E}-3$ & 0.92 & 1.63 & 10.8 & 17.6 & 0.327 & 0.265 \\
\hline
\end{tabular}

${ }^{a}$ In these cases, some or all of the sample material was known to have been lost.

${ }^{b}$ This column gives $\mathrm{E} / \mathrm{C}$ values for the amount of actinide depleted (or burned).

${ }^{c}$ This column gives the calculated value for the amount depleted (or burned) as a percentage.

${ }^{d}$ This column gives the measured amount depleted (or burned) as a percentage.

the ending amount, the $\mathrm{E} / \mathrm{C}$ value for the decrease in the amount of primary actinide (the burn), and both the calculated and measured decrease as a percentage of the starting amount. In the case of ${ }^{233} \mathrm{U},{ }^{238} \mathrm{Pu}$, and one of the ${ }^{244} \mathrm{Cm}$ samples there are no final measured concentrations. Table 2 also shows the one-group fission and capture cross sections that have been flux-averaged over the total irradiation time; these cross sections are in the last two columns of the table. One can see from Table 2 that for the final concentration of the primary actinide there are cases where $\mathrm{E} / \mathrm{C}$ is close to unity, but the comparison of measured to calculated for the amount of actinide burned is nevertheless poor. In such cases, it can be noted that the cross sections and the burn percentages tend to be low. 


\subsection{FISSION-PRODUCT DATA ANALYSIS}

For each of the nine fission-product nuclides listed above (see Sect. 2.1), the number of atoms in an aliquot obtained from the dissolved sample was determined during laboratory analysis. ${ }^{1}$ Four of these fission products $\left({ }^{110 \mathrm{~m}} \mathrm{Ag},{ }^{134} \mathrm{Cs},{ }^{152} \mathrm{Eu}\right.$, and $\left.{ }^{154} \mathrm{Eu}\right)$ are shielded nuclides, and consequently their yields were, in general, lower. In the case of some of the samples, no appreciable concentration could be quoted for ${ }^{110 \mathrm{~m}} \mathrm{Ag}$ or ${ }^{152} \mathrm{Eu}$. Figure 2 is a plot of the $\mathrm{E} / \mathrm{C}$ ratio of fission-product concentrations for three of the plutonium samples. The $\mathrm{E} / \mathrm{C}$ values are plotted versus the fission-product nuclide. The trends in Fig. 2 are typical of the trends seen for most of the other actinide samples (i.e., low for

${ }^{106} \mathrm{Ru}$, high for ${ }^{110 \mathrm{~m}} \mathrm{Ag}$, reasonable for the other seven fission products). Some of these trends are to be expected. For instance, in the case of ruthenium, which evaporates over time, it is not surprising that the measured value is appreciably lower than the calculated value. (The significant part of the irradiation occurred over a period of 900 to 1000 days, and the fission-product analysis was carried out between 600 and 700 days following the end of irradiation.) The low $\mathrm{E} / \mathrm{C}$ value for ${ }^{106} \mathrm{Ru}$ has also been seen in measurements performed at the Japan Atomic Energy Research Institute (JAERI). ${ }^{9}$ The large $\mathrm{E} / \mathrm{C}$ values for ${ }^{110 \mathrm{~m}} \mathrm{Ag}$ are likely the result of an underestimate of the ${ }^{109} \mathrm{Ag}$ capture cross section.

As a first effort to assess the fission-product results, the ${ }^{137} \mathrm{Cs}$ data were studied. One would expect that ${ }^{137} \mathrm{Cs}$ would give the most reliable results-it has a prominent, $662-\mathrm{keV}$ gamma ray, it is located on the high-mass peak of the double-peaked fission-product yield curve, and because of its long half-life $(30 \mathrm{y})$, it is relatively insensitive to the details of the power history. Thus the ${ }^{137} \mathrm{Cs}$ results are expected to be an indicator of the reliability of the other fission-product results.

Figure 3 shows the E/C values for the ${ }^{137} \mathrm{Cs}$ concentrations plotted versus principal sample actinide. Again, data points are shown for all nondosimeter samples for which data were available. Ideally, one would like to have all these values be unity. Alternatively, one might expect them (or the majority of them) to be scattered about some value which is close to unity (because of some systematic normalization issues such as loss of sample material). One can probably say that many of the values in Fig. 3 do, in fact, congregate about some value close to unity but that ${ }^{231} \mathrm{~Pa},{ }^{235} \mathrm{U},{ }^{238} \mathrm{U}$, and ${ }^{242} \mathrm{Pu}$ give $\mathrm{E} / \mathrm{C}$ values that are low and ${ }^{230} \mathrm{Th}$ shows a value that is quite high.

\subsection{TRENDS IN THE DATA}

Figures 1 and 3 serve to identify experimental samples where there may be a problem. Some of these problem cases are common to both the fission-product data and the primary actinide data. Figure 4 is a plot of the $\mathrm{E} / \mathrm{C}$ values for ${ }^{137} \mathrm{Cs}$ versus the $\mathrm{E} / \mathrm{C}$ values for the principal actinide. Ideally, one would like all values to be close to unity. We have seen above that such is not the case. In the absence of such ideal results, however, one might expect a correlation between the fission-product and actinide $\mathrm{E} / \mathrm{C}$ values. Inspection of Fig. 4 shows that this is the case for a majority of the samples.

Six data points in Fig. 4 have been labeled. These five primary actinides are considered to be outside the main cluster in the figure. In the case of ${ }^{236} \mathrm{U},{ }^{238} \mathrm{U},{ }^{242} \mathrm{Pu}$, and ${ }^{243} \mathrm{Cm}$, however, the trend is similar for both ${ }^{137} \mathrm{Cs}$ and the principal actinide. But the ${ }^{230} \mathrm{Th}$ and ${ }^{235} \mathrm{U}$ data points show reasonable values for the primary actinide but not for ${ }^{137} \mathrm{Cs}$. For ${ }^{235} \mathrm{U}$, one would have hoped for better results. 


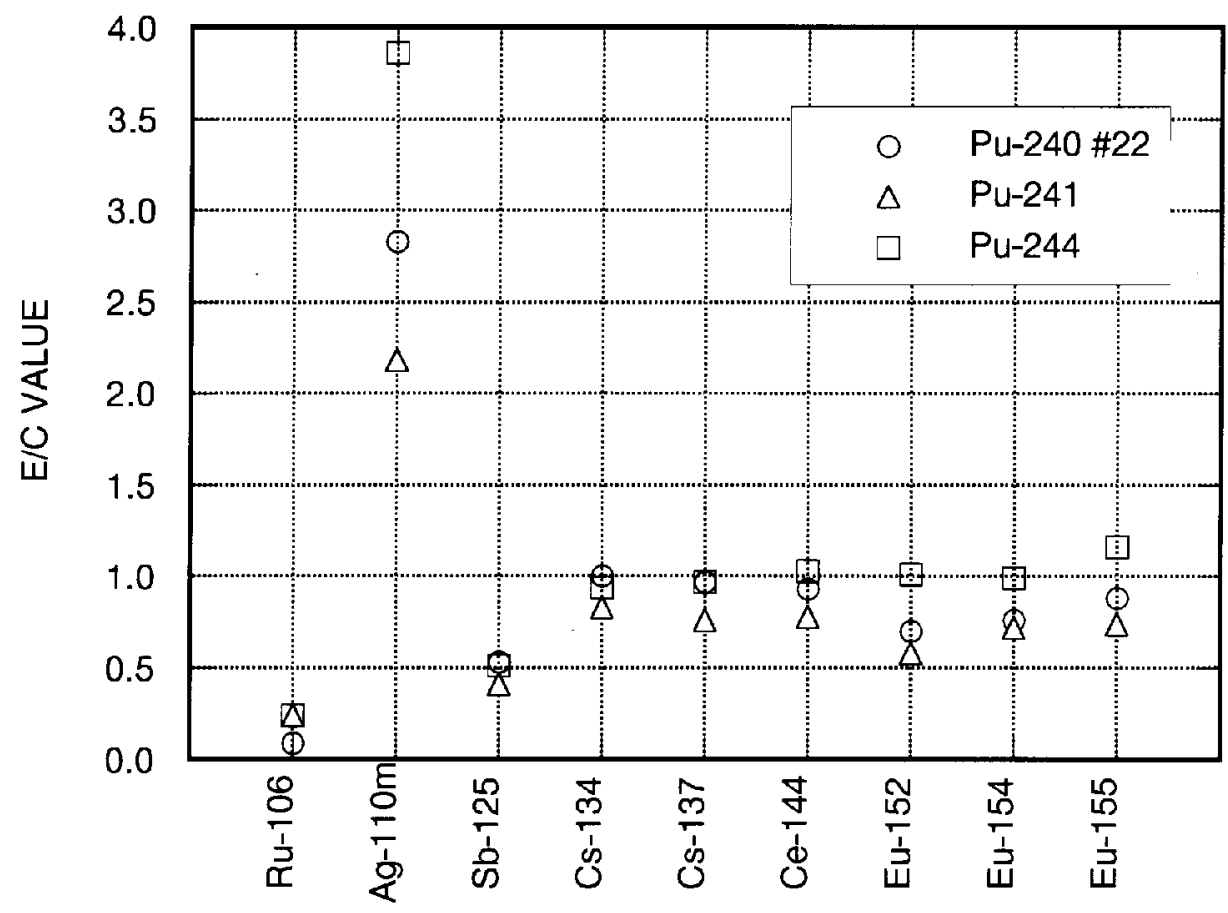

Fig. 2. E/C values for the nine analyzed fission products in the case of three plutonium samples.

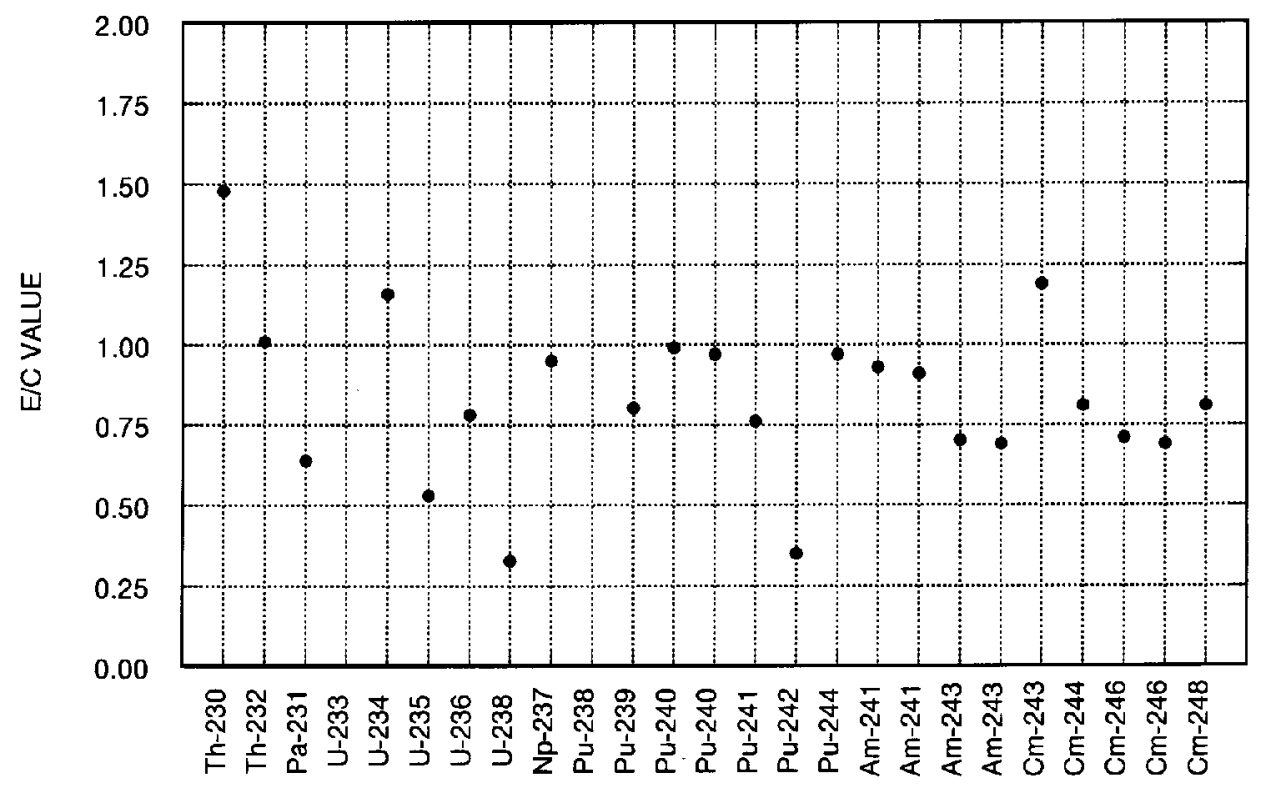

Fig. 3. E/C values for the ${ }^{137} \mathrm{Cs}$ concentration in the actinide samples following initial analysis. Except for four adjusted samples, as explained later, these values are equal to those in Table 6. 


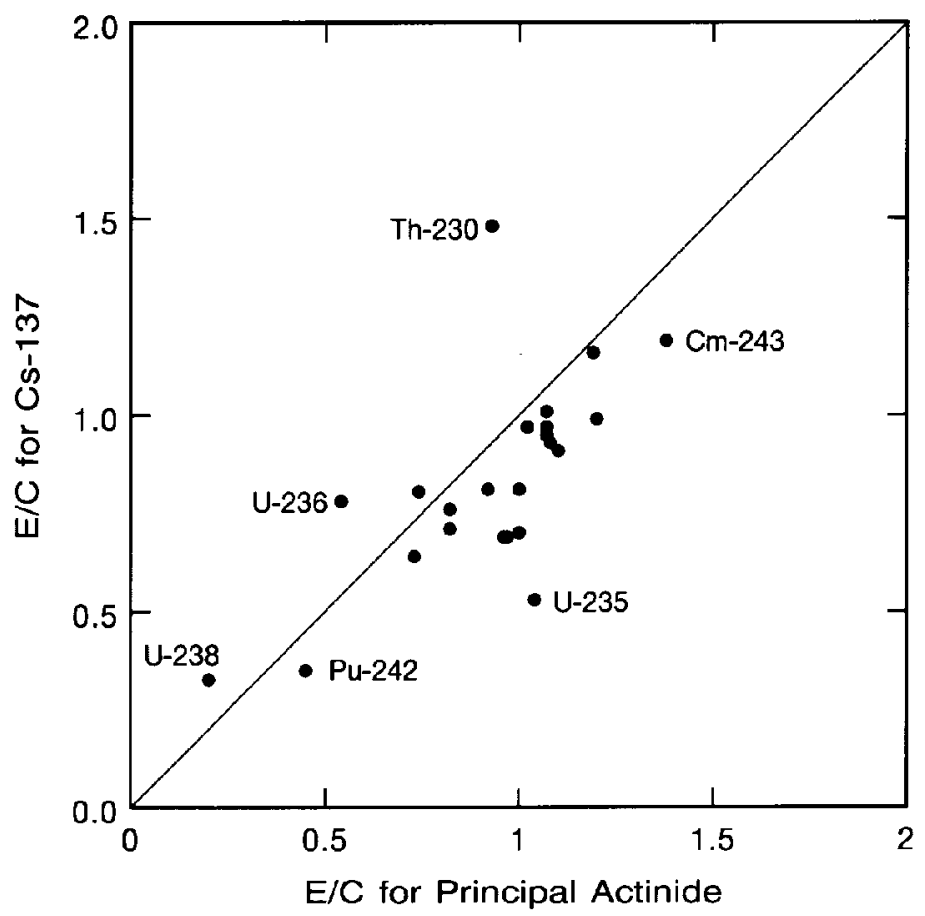

Fig. 4 The E/C values for the ${ }^{137} \mathrm{Cs}$ concentration in the samples versus the $\mathrm{E} / \mathrm{C}$ values for the corresponding principal actinide concentration. This figure combines Figs. 1 and 3.

For the ${ }^{230} \mathrm{Th}$, however, significant uncertainty is possible because the cross sections are low, the sample size was not large, and the only theoretical fission yields available were those for ${ }^{232} \mathrm{Th}$.

\subsection{THE ACTINIDE DOSIMETERS}

We have discussed the initial results from the exposed actinide samples, and we will now review the results from the actinide dosimeters (the copper/cobalt dosimeter results will be reviewed in the next section). Some of the actinide dosimeter results are confusing, and they raise questions that do not have obvious answers. It will be recalled that these dosimeters were grouped in three sets of two dosimeters each. One set was located at each end of FP-4 and the third set was located at the center as follows:

Sample $1:{ }^{235} \mathrm{U} /{ }^{238} \mathrm{U}$

Sample $2:{ }^{237} \mathrm{~Np} /{ }^{239} \mathrm{Pu}$

Sample $17:{ }^{235} \mathrm{U} /{ }^{238} \mathrm{U}$

Sample $18:{ }^{237} \mathrm{~Np} /{ }^{239} \mathrm{Pu}$

Sample $33:{ }^{235} \mathrm{U} /{ }^{238} \mathrm{U}$

Sample $34:{ }^{237} \mathrm{~Np} /{ }^{239} \mathrm{Pu}$ 
Sample 33 was lost in handling, thus leaving two uranium dosimeters and three $\mathrm{Np} / \mathrm{Pu}$ dosimeters. The results from the two uranium dosimeters are reasonably consistent. This is also the case for the agreement among the $\mathrm{Np} / \mathrm{Pu}$ dosimeters. However, the actinide results from both of the uranium dosimeters are surprising and particularly so in light of the close agreement between the two dosimeters. For all these actinide dosimeters, a ${ }^{137} \mathrm{Cs}$ measurement was also obtained. When compared with calculation, the ${ }^{137} \mathrm{Cs}$ results are reasonable. The $\mathrm{E} / \mathrm{C}$ ratios for all measurements are shown in Table 3 for the uranium and $\mathrm{Np} / \mathrm{Pu}$ dosimeters in order.

Table 3. Actinide dosimeter results

${ }^{235} \mathrm{U} /{ }^{238} \mathrm{U}$ dosimeter $\mathrm{E} / \mathrm{C}$ values

\begin{tabular}{|c|c|c|c|c|c|c|}
\hline Sample No. & ${ }^{235} \mathrm{U}$ & ${ }^{236} \mathrm{U}$ & & ${ }^{238} \mathrm{U}$ & ${ }^{239} \mathrm{Pu}$ & ${ }^{137} \mathrm{Cs}$ \\
\hline 1 & 0.56 & 0.58 & & 0.55 & 0.52 & 0.94 \\
\hline 17 & 0.55 & 0.56 & & 0.56 & 0.48 & 0.89 \\
\hline \multicolumn{7}{|c|}{${ }^{237} \mathrm{~Np} /{ }^{239} \mathrm{Pu}$ dosimeter $\mathrm{E} / \mathrm{C}$ values } \\
\hline Sample No. & ${ }^{237} \mathrm{~Np}$ & & ${ }^{238} \mathrm{Pu}$ & & ${ }^{239} \mathrm{Pu}$ & ${ }^{137} \mathrm{Cs}$ \\
\hline 2 & 0.88 & & 1.10 & & 1.01 & 0.90 \\
\hline 18 & 0.87 & & 1.05 & & 1.03 & 0.86 \\
\hline 34 & 0.75 & & 1.02 & & 0.94 & 1.26 \\
\hline
\end{tabular}

The uranium dosimeters give consistently low values for all actinides; however, the ${ }^{137} \mathrm{Cs}$ values are reasonable if somewhat low. That this should be the case for both uranium dosimeters is not readily explainable. The results for the neptunium/plutonium dosimeters are more encouraging.

\subsection{SUMMARY}

We have described the results of the basic data analysis where post-irradiation measurements were compared with calculations. There are some cases where the agreement is noticeably poor. The next section will describe comparisons between samples that allowed us to identify problems with some of the final measured values and thus to make corrections. 


\section{FURTHER ANALYSIS AND CORRECTIONS}

In Sect. 2, total measured amounts of the principal actinides following irradiation were compared with calculated values. Together with the ${ }^{137} \mathrm{Cs}$ data, these serve to give an overall impression of the results. In this section some more detailed analyses will be attempted. Minor actinides will be used to make comparisons between samples and corrections will be proposed.

This section will also refer to a second set of calculations. In addition to the ORIGEN-S calculations (based on ENDF/B-V and ENDF/B-VI), a set of calculations was carried out using a purpose-written burnup code (developed by Dounreay personnel) which employed the 37-group Fast Reactor Dataset 5 (UK/FD5). The UK/FD5 cross-section set derives from the 2240-subgroup FGL5 library ${ }^{10}$ and has been derived for the specific environment of the PFR. However, the results for the fission products from this second set of calculations should be treated with caution. The purposewritten burnup code did not contain all the production chains for the fission products.

In the following sections we will discuss in order the uranium samples, the plutonium samples, the curium samples, the remainder of the actinide samples, and the copper and cobalt dosimeters. The discussions in Sects. 3.1, 3.2, 3.3, and 3.4 are quite detailed. The reader may choose to pursue these details at some later time, and in that case it is suggested that one can review the renormalization process for all the samples from the summary that is presented in Sect. 3.5.

\subsection{URANIUM SAMPLES}

The samples considered in this section are samples $1,11,17,26,27,28$, and $32\left({ }^{235} \mathrm{U} /{ }^{238} \mathrm{U}\right.$, ${ }^{238} \mathrm{U},{ }^{235} \mathrm{U} /{ }^{238} \mathrm{U},{ }^{236} \mathrm{U},{ }^{234} \mathrm{U},{ }^{235} \mathrm{U}$, and $\left.{ }^{233} \mathrm{U}\right)$. The two dosimeters containing ${ }^{235} \mathrm{U}$ and ${ }^{238} \mathrm{U}$ for which measured values are available both show much lower actinide concentration following irradiation than expected. This could have resulted from difficulties in measuring either the initial or final contents (the ${ }^{137} \mathrm{Cs}$ results are reasonable, so the initial contents seem to be correct). The measured results can be normalized, however, on the basis of ${ }^{235} \mathrm{U}$ burnup. The predicted burnup of ${ }^{235} \mathrm{U}$ in the ${ }^{235} \mathrm{U}$ sample (28) is $42.9 \%$, in agreement with the measured burnup of $40.9 \%$. The burnup of ${ }^{235} \mathrm{U}$ is therefore the basis for the normalization. Therefore, we suggest a normalization for sample 1, giving a final concentration for ${ }^{235} \mathrm{U}$ of $0.745 \mathrm{mg}$ and a normalization factor of 1.85. Similarly, the normalization for sample 17 gives a final concentration of $0.644 \mathrm{mg}$ and a normalization factor of 1.90 .

Sample 11 Some of this ${ }^{238} \mathrm{U}$ sample was lost during analysis; however, the final isotopic composition was measured, and this can also be normalized in a similar way to the above. The predicted ${ }^{235} \mathrm{U}$ burnup in the sample is $41.5 \%$; from the result for the ${ }^{235} \mathrm{U}$ sample, the measured ${ }^{235} \mathrm{U}$ burnup can then be extrapolated, giving a final ${ }^{235} \mathrm{U}$ concentration in the sample of $2.57 \mathrm{mg}$. The corresponding final measured value for ${ }^{238} \mathrm{U}$ is $8.4 \mathrm{mg}$. The normalization factor is 4.8 . This is a severe correction.

Sample 26 The ${ }^{236} \mathrm{U}$ sample (26) also shows very low values in the final composition; however, it is again possible to normalize this sample relative to ${ }^{235} \mathrm{U}$ burnup. This gives a final ${ }^{235} \mathrm{U}$ concentration in the sample of $0.488 \mathrm{mg}$, or a normalization factor of 1.96 . This must also be considered a severe correction. 
Sample 32 The ${ }^{233} \mathrm{U}$ sample (32) suffered loss of material during analysis. None of the isotopes can be related to the behavior of isotopes in other samples. This sample was abandoned.

The poor results for both uranium dosimeters have no ready explanation. Although renormalizations have been suggested for the actinide values in these two cases, no further use is being made of the results.

\subsection{PLUTONIUM SAMPLES}

The samples considered here are samples 2, 16, 18, 20, 21, 22, 23, 24, 30, and 34 $\left({ }^{239} \mathrm{Pu} /{ }^{237} \mathrm{~Np},{ }^{242} \mathrm{Pu},{ }^{239} \mathrm{Pu} /{ }^{237} \mathrm{~Np},{ }^{244} \mathrm{Pu},{ }^{240} \mathrm{Pu},{ }^{240} \mathrm{Pu},{ }^{239} \mathrm{Pu},{ }^{241} \mathrm{Pu},{ }^{238} \mathrm{Pu}\right.$, and $\left.{ }^{239} \mathrm{Pu} /{ }^{237} \mathrm{~Np}\right)$. The first observation concerns the three ${ }^{239} \mathrm{Pu}$ dosimeters, all of which have good $\mathrm{E} / \mathrm{C}$ values (see Sect. 2.6) for the ${ }^{239} \mathrm{Pu}$ content $-1.01,1.03$, and 0.94 for samples 2,18 , and 34 , respectively $(1.02,1.06$, and $0.98 \mathrm{UK} / \mathrm{FD} 5)$.

Sample 23 For this ${ }^{239} \mathrm{Pu}$ sample, some material was lost during chemical analysis. A correction was made by setting the ${ }^{239} \mathrm{Pu}$ burnup equal to that of sample 18 multiplied by the flux ratio for the locations of the samples. This gives a burnup of $42.1 \%$. The final concentration of ${ }^{239} \mathrm{Pu}$ then follows from this renormalization and the other isotopic concentrations can be determined from their measured isotopic ratios. The normalization factor is 1.38 .

Samples 21 and 22 Two ${ }^{240} \mathrm{Pu}$ samples (21 and 22) were irradiated next to each other. Their burnups for ${ }^{240} \mathrm{Pu}$ should therefore be about the same. The measured ${ }^{240} \mathrm{Pu}$ burnup in sample 21 is $5.35 \%$, while that in sample 22 is $15.3 \%$. We feel that these two side-by-side samples are probably indications of the measurement accuracy, and we refer the reader to Appendix B for more details.

Samples 16 This ${ }^{242} \mathrm{Pu}$ sample seems to have systematically low final measured concentrations for all isotopes, suggesting loss of sample in dissolution or analysis. The ${ }^{239} \mathrm{Pu}$ burnup in this sample is predicted to be close to that in sample 18. This fact was used to adjust the final concentration values in sample 16. This adjustment required a multiplication of the measured concentration by 2.49 . Because of the implied large loss of sample, the results should be viewed with caution.

Sample 30 The ${ }^{238} \mathrm{Pu}$ sample (30) has an incomplete set of measured values because some of the sample was lost. None of the isotopes in the sample are expected to behave in a similar way to isotopes in other samples, and no correction to the measured values is possible. This sample was abandoned.

\subsection{CURIUM SAMPLES}

There were five curium samples that yielded useful data: $4,5,6,9$, and $10\left({ }^{248} \mathrm{Cm},{ }^{246} \mathrm{Cm}\right.$, ${ }^{246} \mathrm{Cm},{ }^{244} \mathrm{Cm}$, and ${ }^{243} \mathrm{Cm}$ ). A second ${ }^{244} \mathrm{Cm}$ sample (8) was lost during removal from the fuel pin.

The two ${ }^{246} \mathrm{Cm}$ samples gave somewhat different results, but these results were considered to be within the range of experimental accuracy.

The ${ }^{244} \mathrm{Cm}$ and ${ }^{248} \mathrm{Cm}$ samples gave good experimental results. The ${ }^{243} \mathrm{Cm}$ sample was the smallest of all the experimental samples ( $0.39 \mathrm{mg}$ of primary actinide). The results for this sample are subject to considerable experimental uncertainty. 


\subsection{OTHER ACTINIDE SAMPLES}

This section considers sample numbers $7,12,13,14,15,25,29$, and $31\left({ }^{237} \mathrm{~Np},{ }^{243} \mathrm{Am},{ }^{243} \mathrm{Am}\right.$, ${ }^{241} \mathrm{Am},{ }^{241} \mathrm{Am},{ }^{232} \mathrm{Th},{ }^{231} \mathrm{~Pa}$, and ${ }^{230} \mathrm{Th}$ ), the other actinide samples not discussed so far in this section.

The ${ }^{237} \mathrm{~Np}$ sample (7) has a measured burnup of $29.7 \%$ for the primary actinide. The three dosimeters $(2,18$, and 34$)$ give ${ }^{237} \mathrm{~Np}$ measured burnups of $40.2 \%, 44.6 \%$, and $50.0 \%$, respectively. Although these results show variability, they are probably within the range of experimental accuracy.

The two ${ }^{241} \mathrm{Am}$ samples and the two ${ }^{243} \mathrm{Am}$ samples are consistent in their results. They give $\mathrm{E} / \mathrm{C}$ values of 1.08 and 1.10 for ${ }^{241} \mathrm{Am}$ in the ${ }^{241} \mathrm{Am}$ samples and 1.00 and 0.97 for ${ }^{243} \mathrm{Am}$ in the ${ }^{243} \mathrm{Am}$ samples.

For ${ }^{230} \mathrm{Th}(31)$ there are post-irradiation results for the primary actinide and for ${ }^{232} \mathrm{Th}$. There is reasonable agreement with predictions in both cases. The ${ }^{232} \mathrm{Th}$ sample gives an $\mathrm{E} / \mathrm{C}$ value of 1.07 for its ${ }^{232} \mathrm{Th}$ content (1.08 UK/FD5 calculation).

The ${ }^{231} \mathrm{~Pa}$ sample gives an $\mathrm{E} / \mathrm{C}$ of 0.73 for ${ }^{231} \mathrm{~Pa}$ and 0.52 for ${ }^{232} \mathrm{U}$. However, the UK/FD5 calculation gives $\mathrm{E} / \mathrm{C}$ values of 0.58 and 0.62 , respectively. This suggests considerable uncertainties in cross sections.

\subsection{SUMMARY OF THE ACTINIDE CORRECTIONS}

We have discussed possible normalization or corrections involving the uranium dosimeters. The ${ }^{238} \mathrm{U}$ sample (11) was known to have lost material, and it has been possible to correct for this. Material loss for the ${ }^{236} \mathrm{U}$ sample (26) could also be determined, and a correction was carried out for this sample.

It is possible to suggest substantial improvements for two of the plutonium samples. The ${ }^{239} \mathrm{Pu}$ sample (23) had lost material during chemical analysis, and this loss has been estimated. Loss of sample material was suspected for the ${ }^{242} \mathrm{Pu}$ sample (16) and this loss could be confirmed and estimated.

In summary, we show the samples for which adjustments will be made to the experimental values together with the normalization factor by which the original experimental values should be multiplied.

$\begin{array}{lc}\frac{\text { Sample }}{{ }^{236} \mathrm{U}(26)} & \text { Normalization factor } \\ & 1.96 \\ { }^{238} \mathrm{U}(11) & 4.80 \\ { }^{239} \mathrm{Pu}(23) & 1.38 \\ { }^{242} \mathrm{Pu}(16) & 2.49 \\ { }^{235} \mathrm{U} /{ }^{238} \mathrm{U} \text { dosimeter }(1) & 1.85 \\ { }^{235} \mathrm{U}{ }^{238} \mathrm{U} \text { dosimeter }(17) & 1.90\end{array}$

\subsection{COPPER AND COBALT DOSIMETERS}

The results for the copper and ${ }^{59} \mathrm{Co}$ dosimeters are as follows: 
Table 4. E/C values for $\mathrm{Cu} /{ }^{59} \mathrm{Co}$ dosimeters

\begin{tabular}{cllll} 
& \multicolumn{2}{c}{ Cu dosimeter } & \multicolumn{2}{c}{${ }^{59} \mathrm{Co}$ dosimeter } \\
\cline { 2 - 5 } Sample No. & ENDF/B & FD5 & ENDF/B & FD5 \\
\hline 3 & 0.40 & 0.96 & 1.07 & 0.87 \\
19 & 0.55 & 1.33 & 1.12 & 0.92 \\
35 & 0.38 & 0.87 & 1.23 & 0.96 \\
\hline
\end{tabular}

These dosimeter results were not used in the analysis of the actinide samples. They are reported here merely for completeness. For the case of the $\mathrm{Cu}$ dosimeters, a comparison of the cross sections and assumed spectra would aid in an understanding of these results.

\subsection{STATUS OF DATA FOLLOWING CORRECTIONS}

In Table 5, the $\mathrm{E} / \mathrm{C}$ results for the principal isotopes in each sample are listed, and in Table 6 the $\mathrm{E} / \mathrm{C}$ results for ${ }^{137} \mathrm{Cs}$ are listed. Because all corrections to nondosimeter samples were for the purpose of accounting for loss of sample material, any correction applied to the actinides in a nondosimeter sample was also applied to the fission products of the same sample. These tables do not give $\mathrm{E} / \mathrm{C}$ values for samples $8,30,32$, or $33{ }^{244} \mathrm{Cm},{ }^{238} \mathrm{Pu},{ }^{233} \mathrm{U}$, and $\left.{ }^{235} \mathrm{U} /{ }^{238} \mathrm{U}\right)$, all of which suffered partial or total loss of the final sample material.

\subsubsection{Status of Actinide Results}

Of the 39 nuclide comparisons shown in Table 5, seven show E/C values (underlined) that differ by greater than $20 \%$ from unity in the case of ENDF and four do so in the case of FD5. The UK/FD5-calculated results for copper and ${ }^{59} \mathrm{Co}$ suggest that there are cross-section uncertainties in these cases.

The ${ }^{243} \mathrm{Cm}$ sample shows E/C values considerably different from unity. The experimental uncertainty is large for this sample, however. It contained only $0.39 \mathrm{mg}$ of the primary actinide and this is too small a sample on which to base meaningful conclusions (see Appendix B).

When one examines these results in relation to sample location, no recognizable trend can be seen. They do not seem to show a dependence on flux profile, for instance.

\subsubsection{Status of the ${ }^{137}$ Cs Results}

Consider now the ${ }^{137} \mathrm{Cs}$ results (Table 6). Although these results show some differences between the two calculations (ENDF/B-VI and UK/FD5), there are a number of samples for which the agreement is quite good. In the case of both the ENDF/B-VI and the UK/FD5 calculations for the ${ }^{241} \mathrm{Am}$ samples, ${ }^{242 \mathrm{~m}} \mathrm{Am}$ has been assumed to have ${ }^{241} \mathrm{Am}$ fission yields, and both calculations give consistent results with E/C values in the neighborhood of 0.9 . 
Table 5. A comparison of principal actinide

$\mathrm{E} / \mathrm{C}$ values following correction

\begin{tabular}{|c|c|c|c|c|}
\hline \multirow[b]{2}{*}{ Sample No. } & \multirow[b]{2}{*}{ Principal isotope } & \multicolumn{2}{|c|}{$\mathrm{E} / \mathrm{C}$ value } & \multirow[b]{2}{*}{ Notes } \\
\hline & & ENDF/B & FD5 & \\
\hline 1 & ${ }^{235} \mathrm{U}^{a} /{ }^{238} \mathrm{U}^{a}$ & $1.03 / 1.02$ & $1.04 / 1.02$ & Normalization factor $=1.85$ \\
\hline 2 & ${ }^{237} \mathrm{~Np} /{ }^{239} \mathrm{Pu}$ & $0.88 / 1.01$ & $0.94 / 1.02$ & \\
\hline 3 & $\mathrm{Cu} /{ }^{59} \mathrm{Co}$ & $\underline{0.40 / 1.07}$ & $0.96 / 0.87$ & ENDF/B-V cross section suspected \\
\hline 4 & ${ }^{248} \mathrm{Cm}$ & $\overline{0.92}$ & 0.97 & \\
\hline 5 & ${ }^{246} \mathrm{Cm}$ & 0.82 & 0.82 & \\
\hline 6 & ${ }^{246} \mathrm{Cm}$ & 0.96 & 0.96 & \\
\hline 7 & ${ }^{237} \mathrm{~Np}$ & 1.07 & 1.18 & Sample lost \\
\hline 8 & ${ }^{244} \mathrm{Cm}$ & - & - & \\
\hline 9 & ${ }^{244} \mathrm{Cm}$ & 1.00 & 0.97 & \\
\hline 10 & ${ }^{243} \mathrm{Cm}$ & $\underline{1.38}$ & $\underline{1.43}$ & Normalization factor $=4.8$ \\
\hline 11 & ${ }^{238} \mathrm{U}^{a}$ & $\overline{0.94}$ & $\overline{0.95}$ & \\
\hline 12 & ${ }^{243} \mathrm{Am}$ & 1.00 & 1.10 & \\
\hline 13 & ${ }^{243} \mathrm{Am}$ & 0.97 & 1.08 & \\
\hline 14 & ${ }^{241} \mathrm{Am}$ & 1.08 & 1.11 & \\
\hline 15 & ${ }^{241} \mathrm{Am}$ & 1.10 & 1.13 & Normalization factor $=2.49$ \\
\hline 16 & ${ }^{242} \mathrm{Pu}^{a}$ & 1.12 & 1.12 & Normalization factor $=1.90$ \\
\hline 17 & ${ }^{235} \mathrm{U}^{a} / 238 \mathrm{U}^{a}$ & $1.04 / 1.07$ & $1.05 / 1.08$ & \\
\hline 18 & ${ }^{237} \mathrm{~Np} /{ }^{239} \mathrm{Pu}$ & $0.87 / 1.03$ & $0.96 / 1.06$ & ENDF/B-V cross section suspected \\
\hline 19 & $\mathrm{Cu} /{ }^{59} \mathrm{Co}$ & $\underline{0.55 / 1.12}$ & $\underline{1.33 / 0.92}$ & \\
\hline 20 & ${ }^{244} \mathrm{Pu}$ & $\overline{1.02}$ & $\overline{1.07}$ & \\
\hline 21 & ${ }^{240} \mathrm{Pu}$ & 1.20 & $\underline{1.21}$ & Normalization factor $=1.38$ \\
\hline 22 & ${ }^{240} \mathrm{Pu}$ & 1.07 & $\overline{1.08}$ & \\
\hline 23 & ${ }^{239} \mathrm{Pu}^{a}$ & 1.03 & 1.03 & \\
\hline 24 & ${ }^{241} \mathrm{Pu}$ & 0.82 & 0.91 & Normalization factor $=1.96$ \\
\hline 25 & ${ }^{232} \mathrm{Th}$ & 1.07 & 1.08 & \\
\hline 26 & ${ }^{236} \mathrm{U}^{a}$ & 1.05 & 1.07 & \\
\hline 27 & ${ }^{234} \mathrm{U}$ & 1.19 & 1.19 & \\
\hline 28 & ${ }^{235} \mathrm{U}$ & 1.04 & 1.07 & Data abandoned \\
\hline 29 & ${ }^{231} \mathrm{~Pa}$ & $\underline{0.73}$ & $\underline{0.58}$ & \\
\hline 30 & ${ }^{238} \mathrm{Pu}$ & $\overline{-}$ & $\overline{-}$ & Data abandoned \\
\hline 31 & ${ }^{230} \mathrm{Th}$ & 0.93 & 0.99 & Sample lost \\
\hline 32 & ${ }^{233} \mathrm{U}$ & - & - & Sample lost \\
\hline 33 & ${ }^{235} \mathrm{U} /{ }^{238} \mathrm{U}$ & - & - & ENDF/B-V cross section suspected \\
\hline 34 & ${ }^{237} \mathrm{~Np} /{ }^{239} \mathrm{Pu}$ & $\underline{0.75 / 0.94}$ & $0.83 / 0.98$ & \\
\hline 35 & $\mathrm{Cu} /{ }^{59} \mathrm{Co}$ & $\underline{\underline{0.38} / 1.23}$ & $0.87 / 0.96$ & \\
\hline
\end{tabular}

${ }^{a}$ For these samples, corrections were made for material loss. 
We need to emphasize again that the FD5 fission-product calculations are not believed to be as reliable as the other calculations reported here (the complete decay chains were not always included). The ENDF/B results in Table 6 can be summarized by noting that of the 28 results reported, 15 of them yield E/C values that differ from unity by less than $20 \%$.

\subsubsection{Summary of Actinide and ${ }^{137}$ Cs Results}

The unadjusted data presented in Sect. 2 were summarized in Figs. 1, 3, and 4 which show, respectively, the $\mathrm{E} / \mathrm{C}$ ratios for the principal actinides, the $\mathrm{E} / \mathrm{C}$ ratios for ${ }^{137} \mathrm{Cs}$, and the relationship between these E/C ratios. In Figs. 5, 6, and 7 these same quantities are shown following the corrections discussed above.

An overall assessment of the current status of the results can be obtained from Fig. 7. Comparing with Fig. 4, renormalization brings about significant changes for ${ }^{236} \mathrm{U}$ and ${ }^{242} \mathrm{Pu}$. (However, for ${ }^{236} \mathrm{U}$ the $\mathrm{E} / \mathrm{C}$ value for ${ }^{137} \mathrm{Cs}$ is now on the high side.) Neither the ${ }^{230} \mathrm{Th}$ nor the ${ }^{235} \mathrm{U}$ data were adjusted. The ${ }^{230} \mathrm{Th}$ results are likely subject to uncertainty because of low cross sections, but we must conclude that the ${ }^{137} \mathrm{Cs}$ results for ${ }^{235} \mathrm{U}$ are disappointing. 
Table 6. A comparison of ${ }^{137} \mathrm{Cs}$ E/C values following correction

\begin{tabular}{|c|c|c|c|c|}
\hline \multirow[b]{2}{*}{ Sample No. } & \multirow[b]{2}{*}{ Principal isotope } & \multicolumn{2}{|c|}{$\mathrm{E} / \mathrm{C}$ value } & \multirow[b]{2}{*}{ Notes } \\
\hline & & ENDF/B & FD5 & \\
\hline 1 & ${ }^{235} \mathrm{U} /{ }^{238} \mathrm{U}$ & 1.75 & 1.73 & Estimate made of sample loss \\
\hline 2 & ${ }^{239} \mathrm{Pu} /{ }^{237} \mathrm{~Np}$ & 0.90 & 0.92 & \\
\hline 3 & $\mathrm{Cu} /{ }^{59} \mathrm{Co}$ & - & - & \\
\hline 4 & ${ }^{248} \mathrm{Cm}$ & 0.81 & 0.94 & \\
\hline 5 & ${ }^{246} \mathrm{Cm}$ & 0.71 & 0.77 & \\
\hline 6 & ${ }^{246} \mathrm{Cm}$ & 0.70 & 0.77 & \\
\hline 7 & ${ }^{237} \mathrm{~Np}$ & 0.95 & 0.93 & \\
\hline 8 & ${ }^{244} \mathrm{Cm}$ & - & - & Sample lost \\
\hline 9 & ${ }^{244} \mathrm{Cm}$ & 0.81 & 0.82 & \\
\hline 10 & ${ }^{243} \mathrm{Cm}$ & 1.19 & 1.14 & \\
\hline 11 & ${ }^{238} \mathrm{U}$ & 1.57 & - & Estimate made of sample loss \\
\hline 12 & ${ }^{243} \mathrm{Am}$ & 0.70 & 0.73 & \\
\hline 13 & ${ }^{243} \mathrm{Am}$ & 0.69 & 0.72 & \\
\hline 14 & ${ }^{241} \mathrm{Am}$ & 0.93 & 0.88 & \\
\hline 15 & ${ }^{241} \mathrm{Am}$ & 0.91 & 0.87 & \\
\hline 16 & ${ }^{242} \mathrm{Pu}$ & 0.87 & 0.86 & Estimate made of sample loss \\
\hline 17 & ${ }^{235} \mathrm{U} /{ }^{238} \mathrm{U}$ & 1.68 & 1.63 & Estimate made of sample loss \\
\hline 18 & ${ }^{239} \mathrm{Pu} /{ }^{237} \mathrm{~Np}$ & 0.86 & 0.84 & \\
\hline 19 & $\mathrm{Cu} /{ }^{59} \mathrm{Co}$ & - & - & \\
\hline 20 & ${ }^{244} \mathrm{Pu}$ & 0.97 & 1.07 & \\
\hline 21 & ${ }^{240} \mathrm{Pu}$ & 0.99 & 1.01 & \\
\hline 22 & ${ }^{240} \mathrm{Pu}$ & 0.97 & 0.99 & \\
\hline 23 & ${ }^{239} \mathrm{Pu}$ & 1.11 & 1.10 & Estimate made of sample loss \\
\hline 24 & ${ }^{241} \mathrm{Pu}$ & 0.76 & 0.66 & \\
\hline 25 & ${ }^{232} \mathrm{Th}$ & 1.01 & 0.83 & \\
\hline 26 & ${ }^{236} \mathrm{U}$ & 1.54 & 1.58 & Estimate made of sample loss \\
\hline 27 & ${ }^{234} \mathrm{U}$ & 1.16 & 1.24 & \\
\hline 28 & ${ }^{235} \mathrm{U}$ & 0.53 & 0.50 & \\
\hline 29 & ${ }^{231} \mathrm{~Pa}$ & 0.64 & 1.34 & \\
\hline 30 & ${ }^{238} \mathrm{Pu}$ & - & - & Data abandoned \\
\hline 31 & ${ }^{230} \mathrm{Th}$ & 1.48 & - & \\
\hline 32 & ${ }^{233} \mathrm{U}$ & - & - & Data abandoned \\
\hline 33 & ${ }^{235} \mathrm{U} /{ }^{238} \mathrm{U}$ & - & - & Sample lost \\
\hline 34 & ${ }^{239} \mathrm{Pu} /{ }^{237} \mathrm{~Np}$ & 1.26 & 1.20 & \\
\hline 35 & $\mathrm{Cu} /{ }^{59} \mathrm{Co}$ & - & - & \\
\hline
\end{tabular}




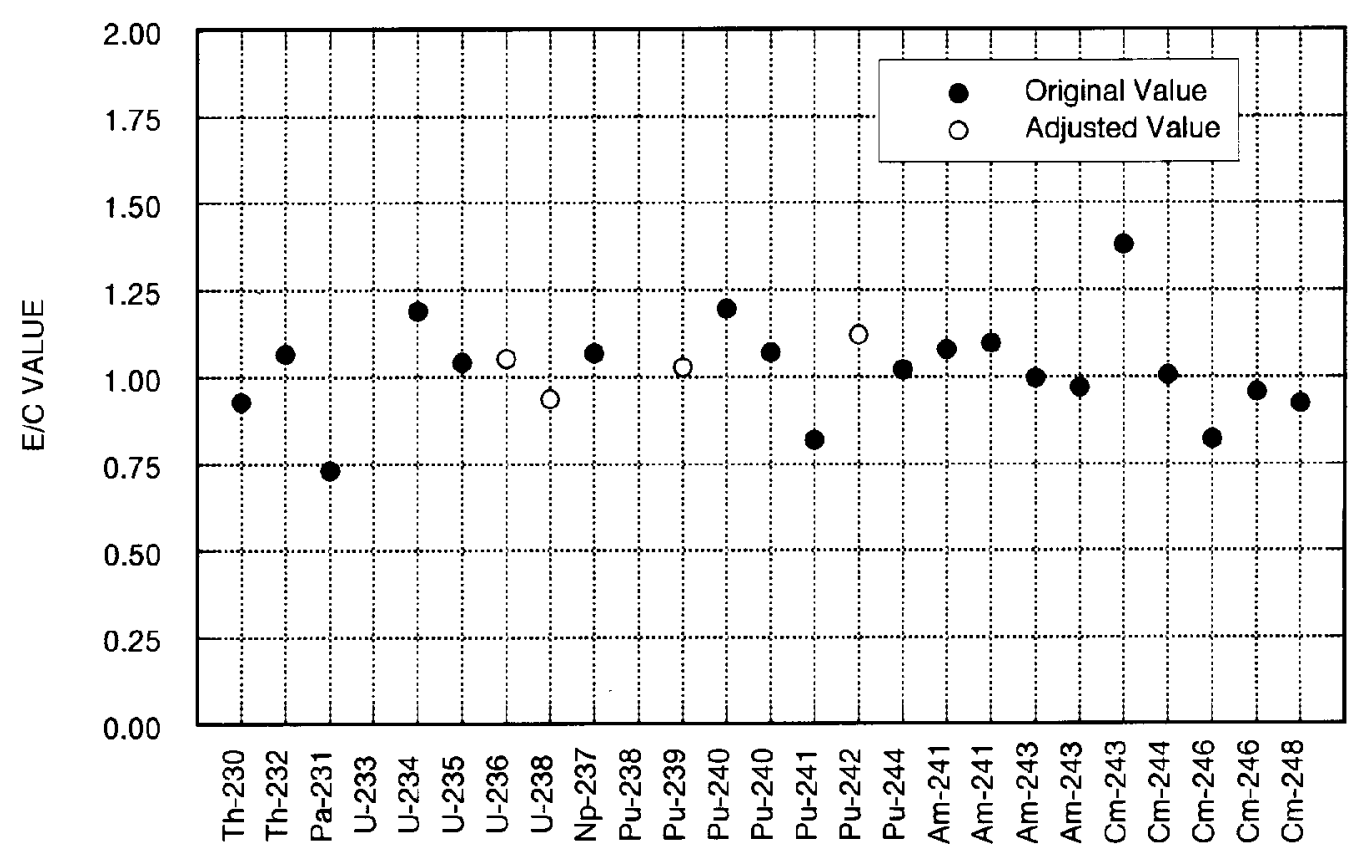

Fig. 5. Adjusted E/C values for the primary actinide concentrations following corrections (compare with Fig. 1). The values used for this plot are listed in column 6 of Table 7.

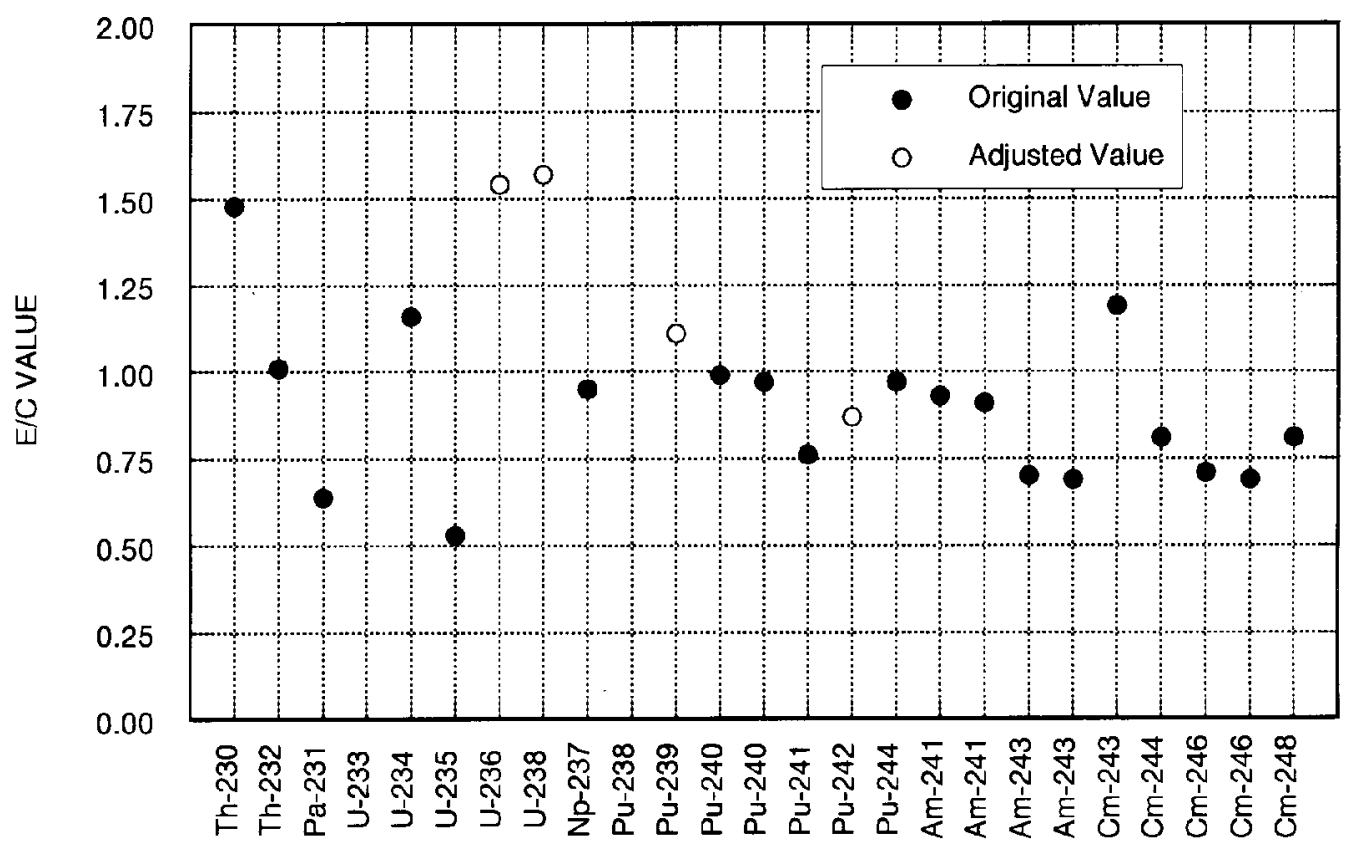

Fig. 6. Adjusted $\mathrm{E} / \mathrm{C}$ values for the ${ }^{137} \mathrm{Cs}$ concentration in the actinide samples following correction (compare with Fig. 3). These are the ENDF E/C values for the nondosimeter samples from Table 6. The ${ }^{236} \mathrm{U}$ and ${ }^{242} \mathrm{Pu}$ values have been renormalized as compared to Fig. 3, and values have been added for ${ }^{238} \mathrm{U}$ and ${ }^{239} \mathrm{Pu}$. 


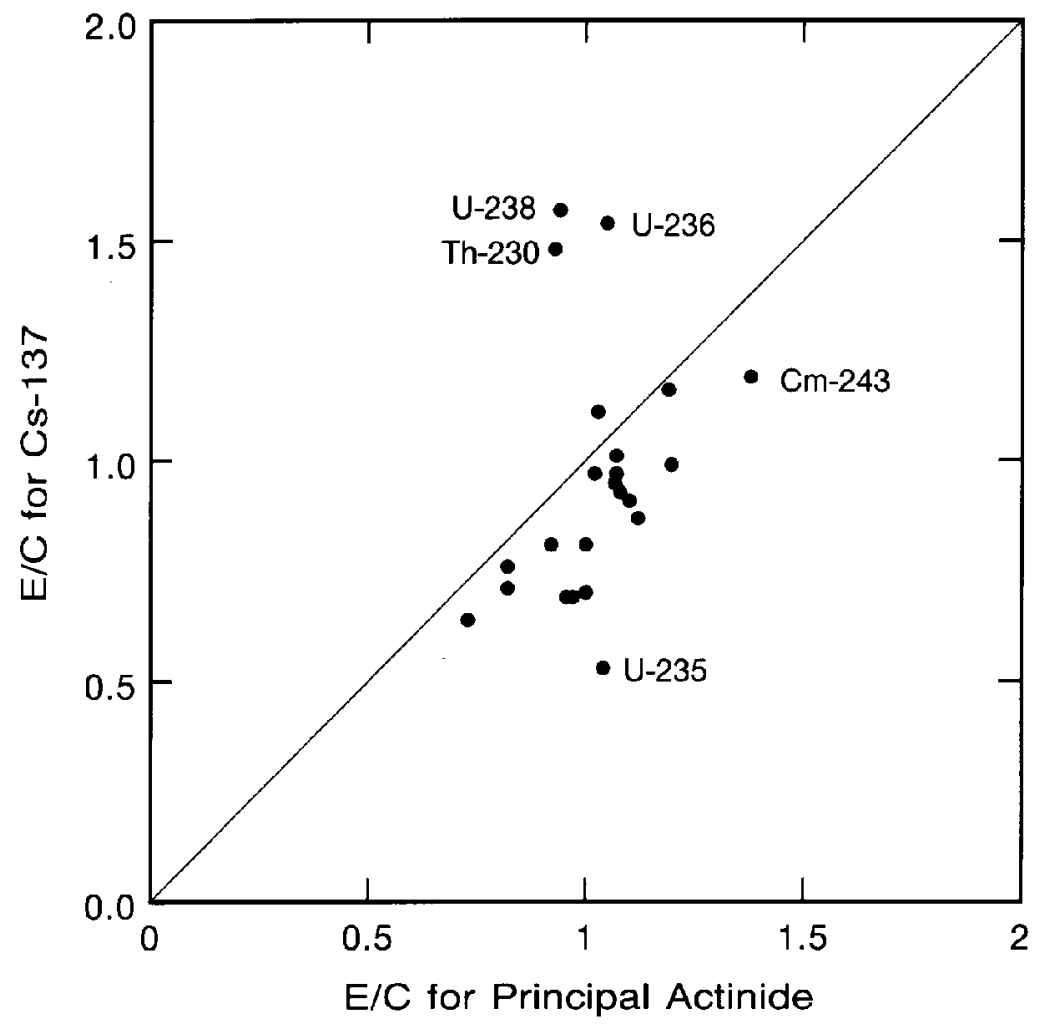

Fig. 7. The E/C values for the ${ }^{137} \mathrm{Cs}$ concentration in the samples versus the $\mathrm{E} / \mathrm{C}$ values for the corresponding principal actinide concentration, following correction (compare with Fig. 4). 


\section{ACTINIDE DEPLETION AND IRRADIATION-PRODUCT RESULTS}

The discussion in the previous section shows that by comparing the isotopic components of the samples, one can adjust for a significant amount of measurement uncertainty contributing to some poor initial results. This adjustment applies to 4 out of 23 samples. In an earlier part of this report, Table 2 shows E/C values for the principal actinides (nondosimeter samples) following irradiation, as well as E/C values for the amount burned in each case. Table 7 is an updated version of Table 2. It shows the same data items following renormalization. There is, however, an important distinction that needs to be noted between Tables 2 and 7. In Table 2, the "Ending" values (both measured and calculated) refer to the dates on which actual laboratory measurements were performed. (These dates are given in Appendix B of ref. 1.) In Table 7, on the other hand, these values are for the end-ofirradiation date (the measured values were "backed-off" to this date). This distinction between the tables is noticeable only in the case of short-lived nuclides. Even so, it does not affect E/C values.

We noted earlier that the value of $\mathrm{E} / \mathrm{C}$ for the principal actinide (and, in fact, for other actinides present before irradiation) may not always be an optimal indicator of our calculational accuracy. If the burnup is small, the $\mathrm{E} / \mathrm{C}$ values can be good irrespective of the accuracy of the cross sections. It is also useful to compare the experimental and calculated values for the amount burned, but, again, if the burnup is small, measurement uncertainties may not yield meaningful results. In the case of irradiation products not originally present in the samples, the situation is simpler. In such cases, the $\mathrm{E} / \mathrm{C}$ value of the amount of the species following irradiation is the only criterion for assessment.

Tables 8 and 9 present results for the amount of irradiation product produced and for the amount of pre-existing actinides burned, respectively. Generally speaking, Table 8 refers to actinides not originally present in a sample. However, in some instances, where a very small amount of an actinide is present before irradiation and a much larger amount is produced, we have chosen to include such cases in Table 8 (i.e., the original concentration can be considered zero for all practical purposes). The complete list of irradiation products is given in Table D.1.

\subsection{IRRADIATION-PRODUCT RESULTS}

The product nuclides shown in Table 8 are species which, for all practical purposes, were not present before irradiation. In some instances, a small amount of a nuclide was present in the original sample, and if this amount was deemed to be negligible, the nuclide is listed in Table 8. Most of the nuclides in Table 8 are neutron-capture products arising from the nuclides already present in the samples. A minority of the species in Table 8 are produced by a more complicated set of pathways.

The E/C values shown in Table 8 are reasonably close to unity in many cases. Thus one can conclude that many cross sections are known with reasonable accuracy. However, they are perhaps not known with great accuracy. The detailed discussion of individual cases must await further analysis.

For three principal actinides $\left({ }^{240} \mathrm{Pu},{ }^{241} \mathrm{Am}\right.$, and $\left.{ }^{243} \mathrm{Am}\right)$ there are two samples of each shown in Table 8. Note that for these three sets of doublets the results in the table are consistent. 
Table 7. Summary of principal actinide results following adjustment (nondosimeter samples)

\begin{tabular}{|c|c|c|c|c|c|c|c|c|c|c|}
\hline Nuclide & $\begin{array}{c}\text { Sample } \\
\text { No. }\end{array}$ & $\begin{array}{l}\text { Starting } \\
\text { value } \\
\text { (grams) }\end{array}$ & $\begin{array}{l}\text { Ending } \\
\text { measured } \\
\text { (grams) }\end{array}$ & $\begin{array}{c}\text { Ending } \\
\text { calculated } \\
\text { (grams) }\end{array}$ & $\begin{array}{c}E / C \\
\text { at end }\end{array}$ & $\begin{array}{l}\mathrm{E} / \mathrm{C} \text { of } \\
\text { burn }\end{array}$ & $\begin{array}{l}\% \text { burn } \\
\text { (calc) }\end{array}$ & $\begin{array}{l}\% \text { burn } \\
\text { (meas) }\end{array}$ & $\begin{array}{r}\mathrm{F}(\mathrm{n}, \mathrm{f}) \\
\text { one-g1 } \\
(\mathrm{bar}\end{array}$ & $\begin{array}{l}F(n,() \\
\text { roup } \\
\text { ns })\end{array}$ \\
\hline Th-230 & 31 & $2.88 \mathrm{E}-3$ & $2.54 \mathrm{E}-3$ & $2.74 \mathrm{E}-3$ & 0.93 & 2.43 & 4.9 & 11.8 & 0.032 & 0.207 \\
\hline Th-232 & 25 & $1.88 \mathrm{E}-2$ & $1.81 \mathrm{E}-2$ & $1.70 \mathrm{E}-2$ & 1.07 & 0.38 & 9.6 & 3.7 & 0.011 & 0.427 \\
\hline $\mathrm{Pa}-231$ & 29 & $2.51 \mathrm{E}-3$ & $9.00 \mathrm{E}-4$ & $1.23 \mathrm{E}-3$ & 0.73 & 1.26 & 51.0 & 64.2 & 0.265 & 3.067 \\
\hline $\mathrm{U}-233$ & 32 & $7.65 \mathrm{E}-3$ & - & $4.00 \mathrm{E}-3$ & - & - & 47.7 & - & 2.846 & 0.286 \\
\hline U-234 & 27 & $3.50 \mathrm{E}-3$ & $3.33 \mathrm{E}-3$ & $2.80 \mathrm{E}-3$ & 1.19 & 0.24 & 20.0 & 4.9 & 0.357 & 0.659 \\
\hline U-235 & 28 & $8.37 \mathrm{E}-3$ & $4.96 \mathrm{E}-3$ & $4.78 \mathrm{E}-3$ & 1.04 & 0.95 & 42.9 & 40.7 & 2.000 & 0.602 \\
\hline U-236 & $26^{a}$ & 7.96E-3 & $7.23 \mathrm{E}-3$ & $6.88 \mathrm{E}-3$ & 1.05 & 0.68 & 13.6 & 9.2 & 0.111 & 0.593 \\
\hline U-238 & $11^{a}$ & $9.81 \mathrm{E}-3$ & $8.40 \mathrm{E}-3$ & $8.97 \mathrm{E}-3$ & 0.94 & 1.68 & 8.6 & 14.4 & 0.045 & 0.374 \\
\hline Np-237 & 7 & $1.22 \mathrm{E}-2$ & $8.59 \mathrm{E}-3$ & $8.05 \mathrm{E}-3$ & 1.07 & 0.87 & 34.1 & 29.7 & 0.361 & 1.676 \\
\hline $\mathrm{Pu}-238$ & 30 & $3.11 \mathrm{E}-3$ & - & $1.77 \mathrm{E}-3$ & - & - & 43.1 & - & 1.224 & 0.790 \\
\hline $\mathrm{Pu}-239$ & $23^{a}$ & $8.47 \mathrm{E}-3$ & $4.90 \mathrm{E}-3$ & $4.77 \mathrm{E}-3$ & 1.03 & 0.96 & 43.7 & 42.2 & 1.905 & 0.584 \\
\hline $\mathrm{Pu}-240$ & 21 & $1.08 \mathrm{E}-2$ & $1.03 \mathrm{E}-2$ & $8.57 \mathrm{E}-3$ & 1.20 & 0.26 & 20.9 & 5.4 & 0.400 & 0.621 \\
\hline $\mathrm{Pu}-240$ & 22 & $1.08 \mathrm{E}-2$ & $9.16 \mathrm{E}-3$ & $8.56 \mathrm{E}-3$ & 1.07 & 0.73 & 21.0 & 15.3 & 0.400 & 0.621 \\
\hline $\mathrm{Pu}-241$ & 24 & $4.21 \mathrm{E}-3$ & $1.29 \mathrm{E}-3$ & $1.57 \mathrm{E}-3$ & 0.82 & 1.11 & 62.7 & 69.4 & 2.622 & 0.498 \\
\hline $\mathrm{Pu}-242$ & $16^{a}$ & $2.05 \mathrm{E}-3$ & $1.94 \mathrm{E}-3$ & $1.73 \mathrm{E}-3$ & 1.12 & 0.34 & 15.6 & 5.4 & 0.284 & 0.472 \\
\hline Pu-244 & 20 & $2.11 \mathrm{E}-3$ & $1.91 \mathrm{E}-3$ & $1.88 \mathrm{E}-3$ & 1.02 & 0.87 & 10.9 & 9.5 & 0.238 & 0.269 \\
\hline Am-241 & 14 & $9.40 \mathrm{E}-3$ & $6.23 \mathrm{E}-3$ & $5.78 \mathrm{E}-3$ & 1.08 & 0.88 & 38.5 & 33.7 & 0.315 & 1.872 \\
\hline Am-241 & 15 & $9.50 \mathrm{E}-3$ & $6.38 \mathrm{E}-3$ & $5.82 \mathrm{E}-3$ & 1.10 & 0.85 & 38.7 & 32.8 & 0.315 & 1.872 \\
\hline Am-243 & 12 & $9.83 \mathrm{E}-3$ & $6.79 \mathrm{E}-3$ & $6.82 \mathrm{E}-3$ & 1.00 & 1.01 & 30.6 & 30.9 & 0.246 & 1.452 \\
\hline Am-243 & 13 & $9.80 \mathrm{E}-3$ & $6.60 \mathrm{E}-3$ & $6.77 \mathrm{E}-3$ & 0.97 & 1.06 & 30.9 & 32.7 & 0.246 & 1.452 \\
\hline $\mathrm{Cm}-243$ & 10 & $3.72 \mathrm{E}-4$ & $2.30 \mathrm{E}-4$ & $1.66 \mathrm{E}-4$ & 1.38 & 0.69 & 55.4 & 38.3 & 2.844 & 0.274 \\
\hline $\mathrm{Cm}-244$ & 8 & - & - & - & - & - & - & - & 0.456 & 0.884 \\
\hline $\mathrm{Cm}-244$ & 9 & 7.93E-3 & $4.78 \mathrm{E}-3$ & $4.76 \mathrm{E}-3$ & 1.00 & 0.99 & 40.0 & 39.7 & 0.456 & 0.884 \\
\hline $\mathrm{Cm}-246$ & 5 & $6.69 \mathrm{E}-3$ & $4.92 \mathrm{E}-3$ & $5.99 \mathrm{E}-3$ & 0.82 & 2.53 & 10.5 & 26.5 & 0.291 & 0.263 \\
\hline $\mathrm{Cm}-246$ & 6 & $6.80 \mathrm{E}-3$ & $5.81 \mathrm{E}-3$ & $6.08 \mathrm{E}-3$ & 0.96 & 1.38 & 10.6 & 14.6 & 0.291 & 0.263 \\
\hline $\mathrm{Cm}-248$ & 4 & $1.76 \mathrm{E}-3$ & $1.45 \mathrm{E}-3$ & $1.57 \mathrm{E}-3$ & 0.92 & 1.63 & 10.8 & 17.6 & 0.327 & 0.265 \\
\hline
\end{tabular}

\footnotetext{
${ }^{a}$ These are the samples that were adjusted.
} 


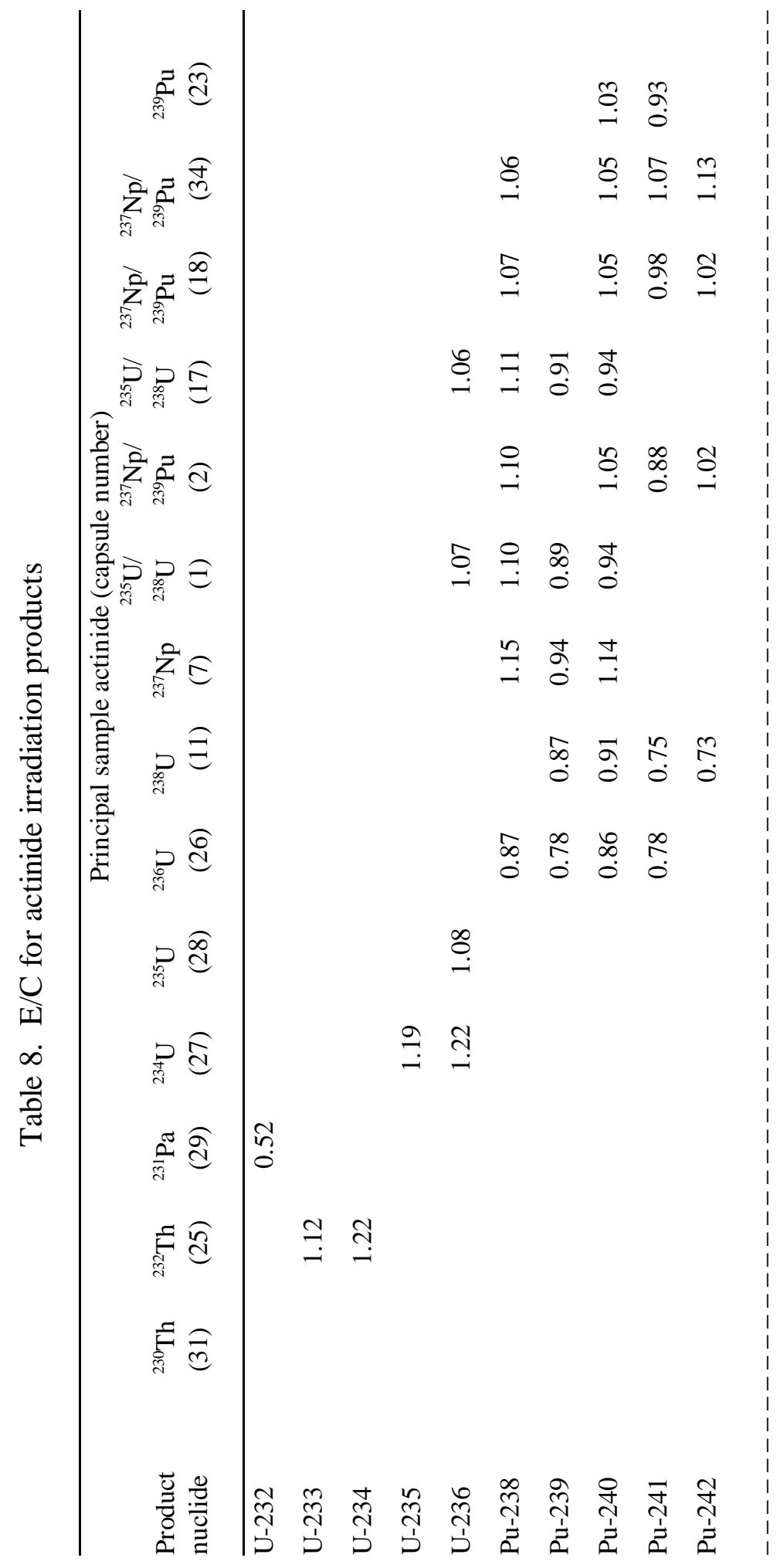




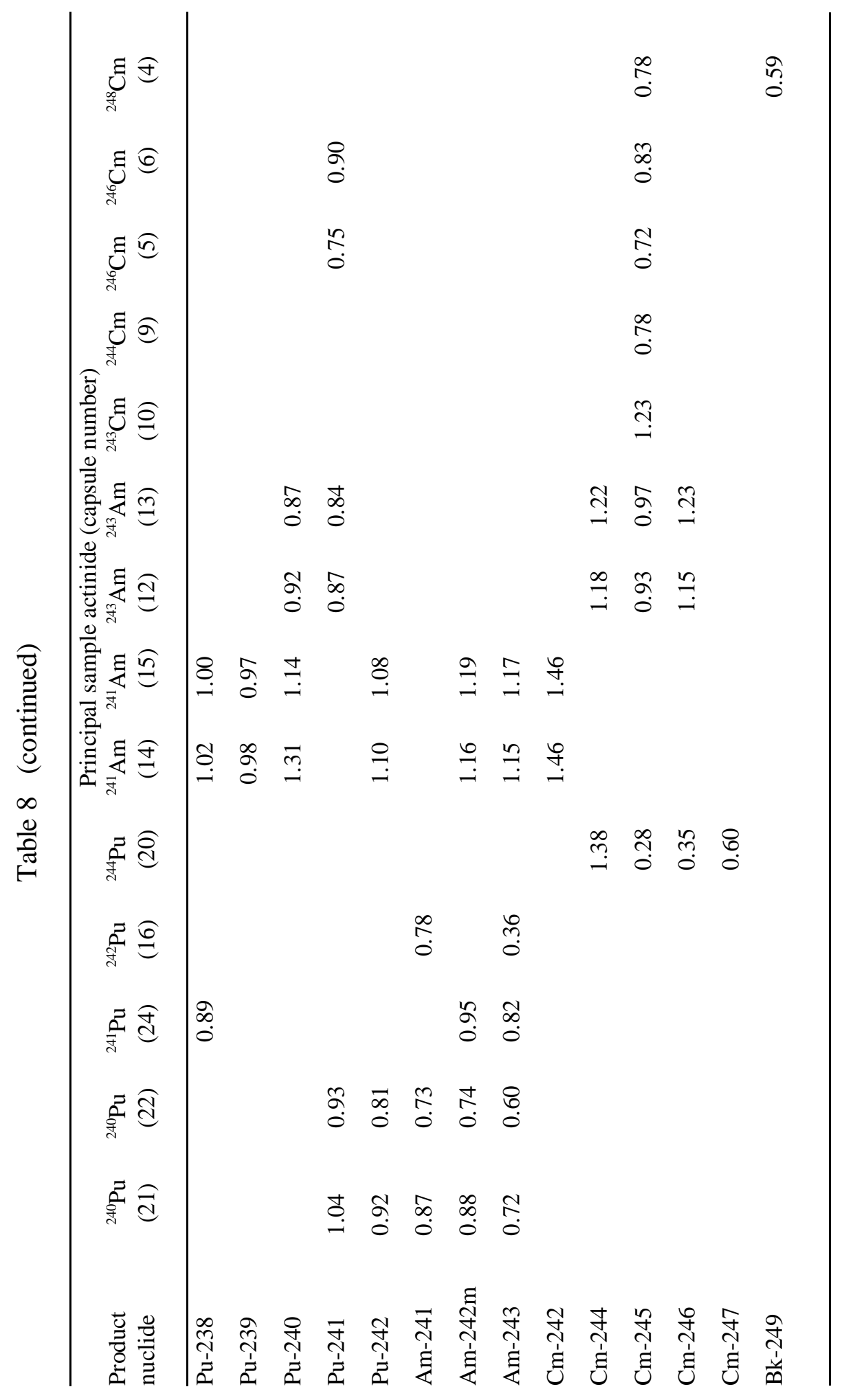




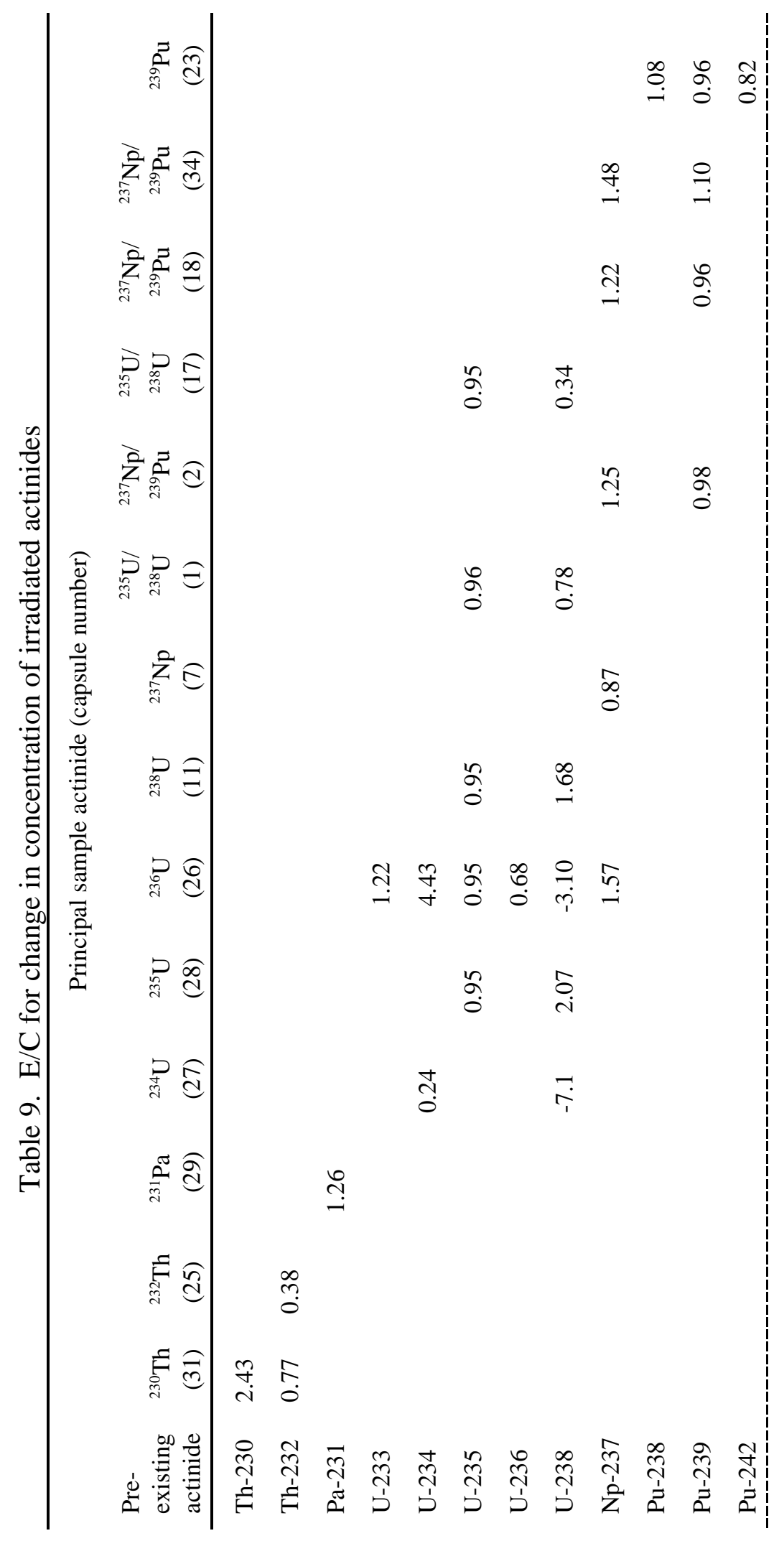




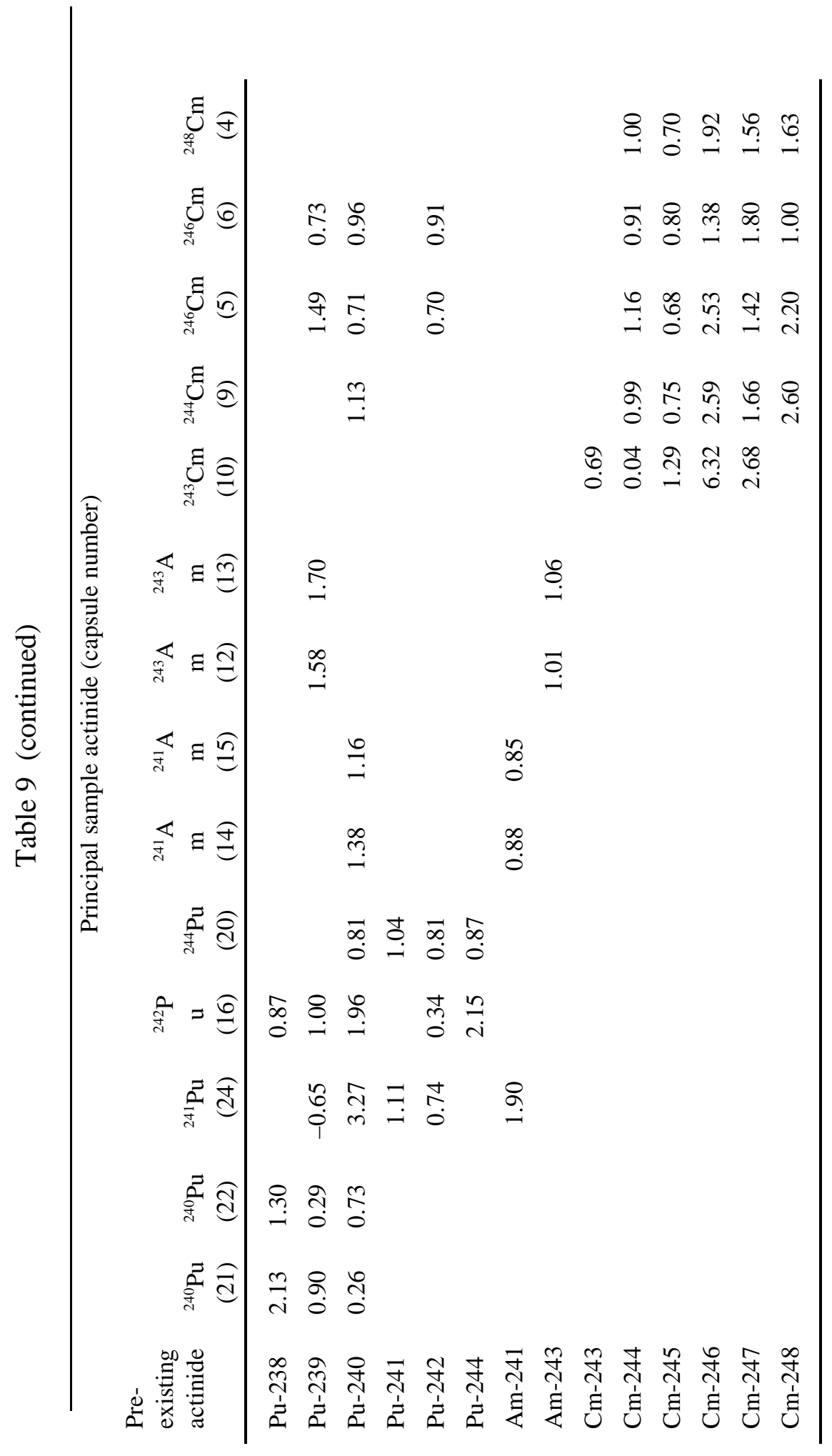




\subsection{DEPLETION OF IRRADIATED ACTINIDES}

Table 7 showed the E/C values for the final amount of each principal actinide for which useable data were available. These and $\mathrm{E} / \mathrm{C}$ values for other minor nuclides present in the samples are also summarized in Table D.1. Referring again to Table 7, note that it also contains E/C values for the amount of each principal actinide that was burned. This latter $\mathrm{E} / \mathrm{C}$ value is a more demanding indicator of the agreement between experiment and theory than is the $\mathrm{E} / \mathrm{C}$ value for the final amount of the actinide itself. Rather than simply comparing the laboratory measurement of the concentration of an actinide with the predicted concentration, one compares the amount of actinide that is depleted using measured and predicted final concentrations.

Table 9 shows $\mathrm{E} / \mathrm{C}$ values for the depletion of actinides present in the irradiated samples. It includes the actinide dosimeter samples. Besides the principal actinides shown in Table 7, Table 9 shows many other actinides present in the original samples. The results shown in Table 9 are complimentary to results discussed so far. However, as already indicated, they result from a more demanding test, and, practically speaking, they may not be as useful as the $\mathrm{E} / \mathrm{C}$ values for the concentrations themselves. If the amount of depletion occurring is negligible, then the $\mathrm{E} / \mathrm{C}$ value is not useful, and, in fact, the depletion may be poorly predicted. However, the amount of actinide remaining will be well predicted. 


\section{FISSION-PRODUCT RESULTS}

\subsection{SUMMARY OF FISSION-PRODUCT RESULTS}

The ${ }^{137} \mathrm{Cs}$ results were presented in Fig. 6, and they give a sense of the agreement between experiment and simulation. More detailed results for the nine fission products will be presented below. Figure 6 can perhaps be summed up as follows: the thorium, protactinium, and uranium samples show variable results; the neptunium, plutonium, and ${ }^{241} \mathrm{Am}$ results are reasonable; and the ${ }^{243} \mathrm{Am}$ and curium isotopes give consistent, if somewhat low, $\mathrm{E} / \mathrm{C}$ values (the ${ }^{243} \mathrm{Cm}$ result is probably not reliable).

The ${ }^{137} \mathrm{Cs}$ results that seem seriously out of line are those for ${ }^{230} \mathrm{Th},{ }^{231} \mathrm{~Pa},{ }^{235} \mathrm{U},{ }^{236} \mathrm{U}$, and ${ }^{238} \mathrm{U}$. The ${ }^{230} \mathrm{Th}$ result will be subject to much uncertainty. The fission cross section is low and the fission yields used are those for ${ }^{232} \mathrm{Th}$. For ${ }^{231} \mathrm{~Pa}$, showing a low E/C value, the actinide itself also shows a low value leading one to suspect an underestimate of the amount of the final sample.

For comparison purposes the ENDF/B-VI fission yields employed for ${ }^{137} \mathrm{Cs}$ are shown in Fig. 8, together with their associated uncertainties. Note, however, that for ${ }^{230} \mathrm{Th}$, yield data from ${ }^{232} \mathrm{Th}$ were used, and for ${ }^{244} \mathrm{Pu},{ }^{242} \mathrm{Pu}$ yield data were employed. Therefore, in the case of both of these nuclides we have indicated the uncertainty as being equal to the maximum uncertainty seen among the other evaluated yields.

\subsection{SAMPLE-BY-SAMPLE RESULTS}

In Fig. 2 the E/C ratios were shown for the nine analyzed fission products resulting from three of the plutonium samples. The trend of these results is fairly typical. The noteworthy aspects of the results are that the $\mathrm{E} / \mathrm{C}$ values for ${ }^{106} \mathrm{Ru}$ are low for all actinide samples, and for ${ }^{110 \mathrm{~m}} \mathrm{Ag}$ the $\mathrm{E} / \mathrm{C}$ values are consistently high. The low values for ${ }^{106} \mathrm{Ru}$ seem to be explained by the fact that the ruthenium evaporates. In the case of ${ }^{110 \mathrm{~m}} \mathrm{Ag}$, which is a shielded nuclide, perhaps the neutron capture cross section used for ${ }^{109} \mathrm{Ag}$ is uncertain.

Because all ${ }^{106} \mathrm{Ru}$ and ${ }^{110 \mathrm{~m}} \mathrm{Ag}$ results will be similar to those in Fig. 2, the figures that follow will omit these two fission products. Figures 9 through 15 show E/C values versus principal actinide for the fission products ${ }^{125} \mathrm{Sb},{ }^{134} \mathrm{Cs},{ }^{137} \mathrm{Cs},{ }^{144} \mathrm{Ce},{ }^{152} \mathrm{Eu},{ }^{154} \mathrm{Eu}$, and ${ }^{155} \mathrm{Eu}$, respectively. Note that Fig. 11 is a repeat of Fig. $6\left({ }^{137} \mathrm{Cs}\right)$. It is presented a second time for completeness.

As one examines Figs. 9 through 15, one can see the extent of agreement between experiment and calculation for the various samples. The results for these other fission products are showing many of the trends that were evident in the case of ${ }^{137} \mathrm{Cs}$. Not all fission products could be measured in the case of all the samples and some data points are consequently missing. 


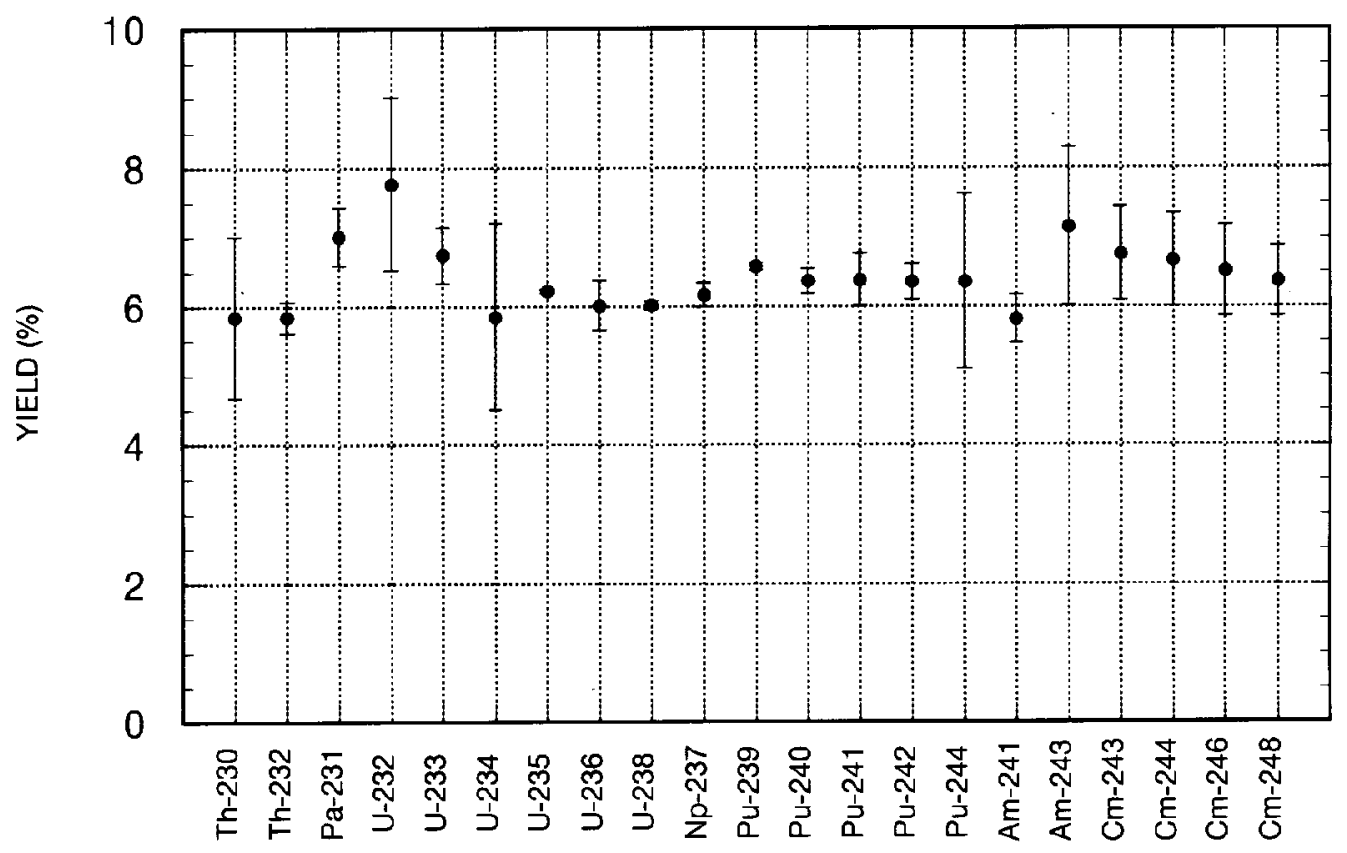

Fig. 8. The ${ }^{137} \mathrm{Cs}$ fission yields from ENDF/B-VI for the actinides of interest.

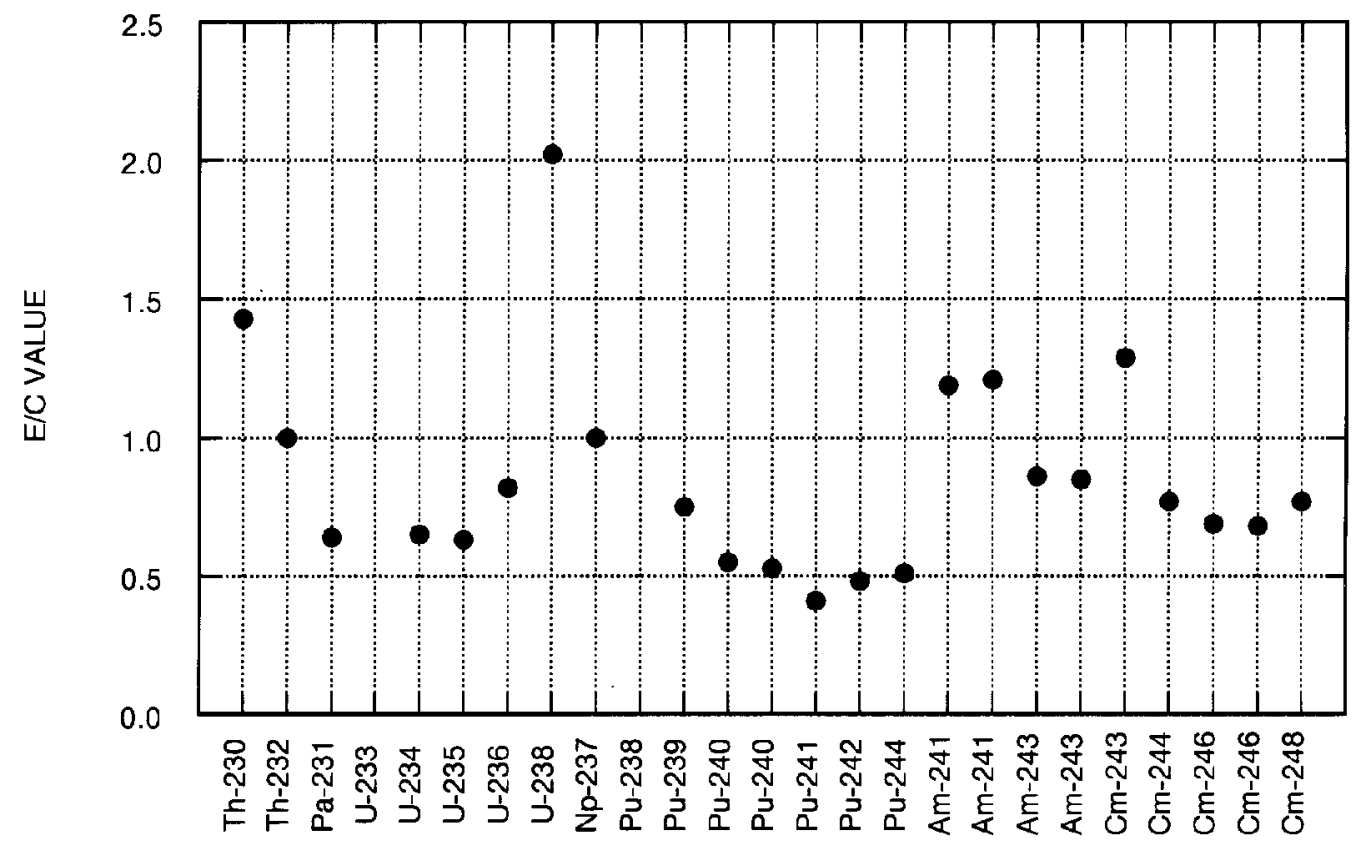

Fig. 9. E/C ratio for the ${ }^{125} \mathrm{Sb}$ concentration in the actinide samples. These and the E/C values that follow for other fission products are from Table F.1. 


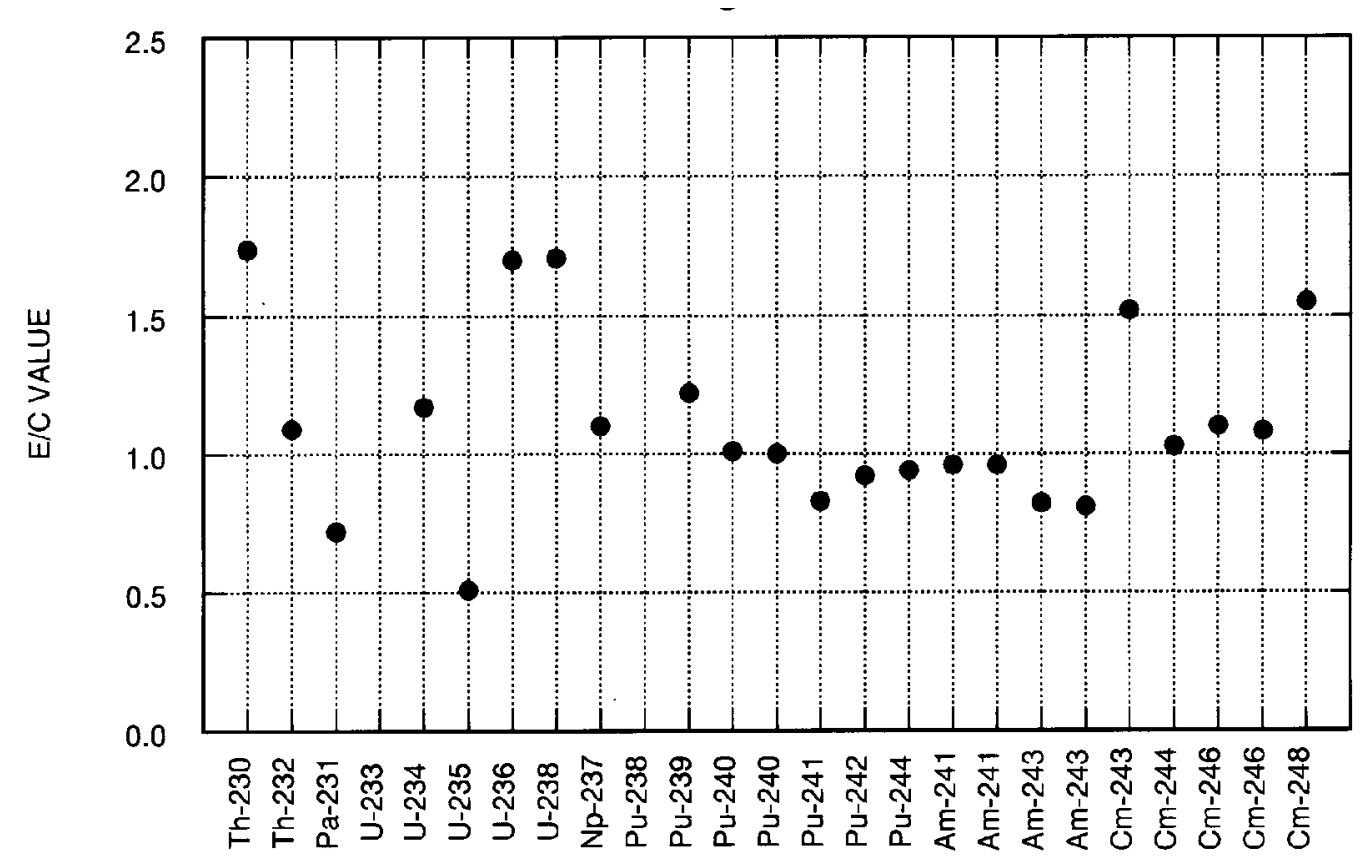

Fig. 10. E/C values for the ${ }^{134} \mathrm{Cs}$ concentration in the actinide samples.

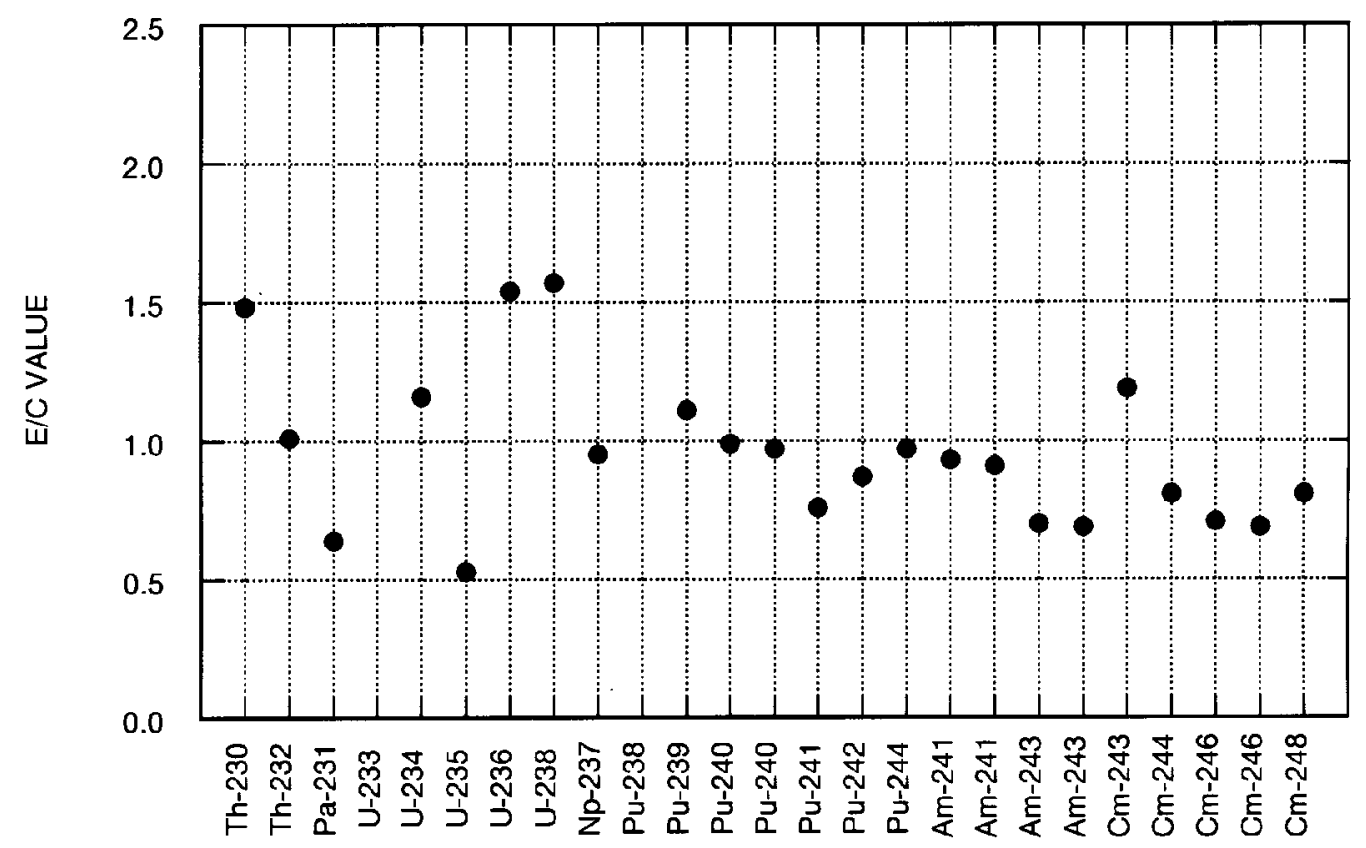

Fig. 11. E/C values for the ${ }^{137} \mathrm{Cs}$ concentration in the actinide samples. This is a repeat of the data in Fig. 6. 


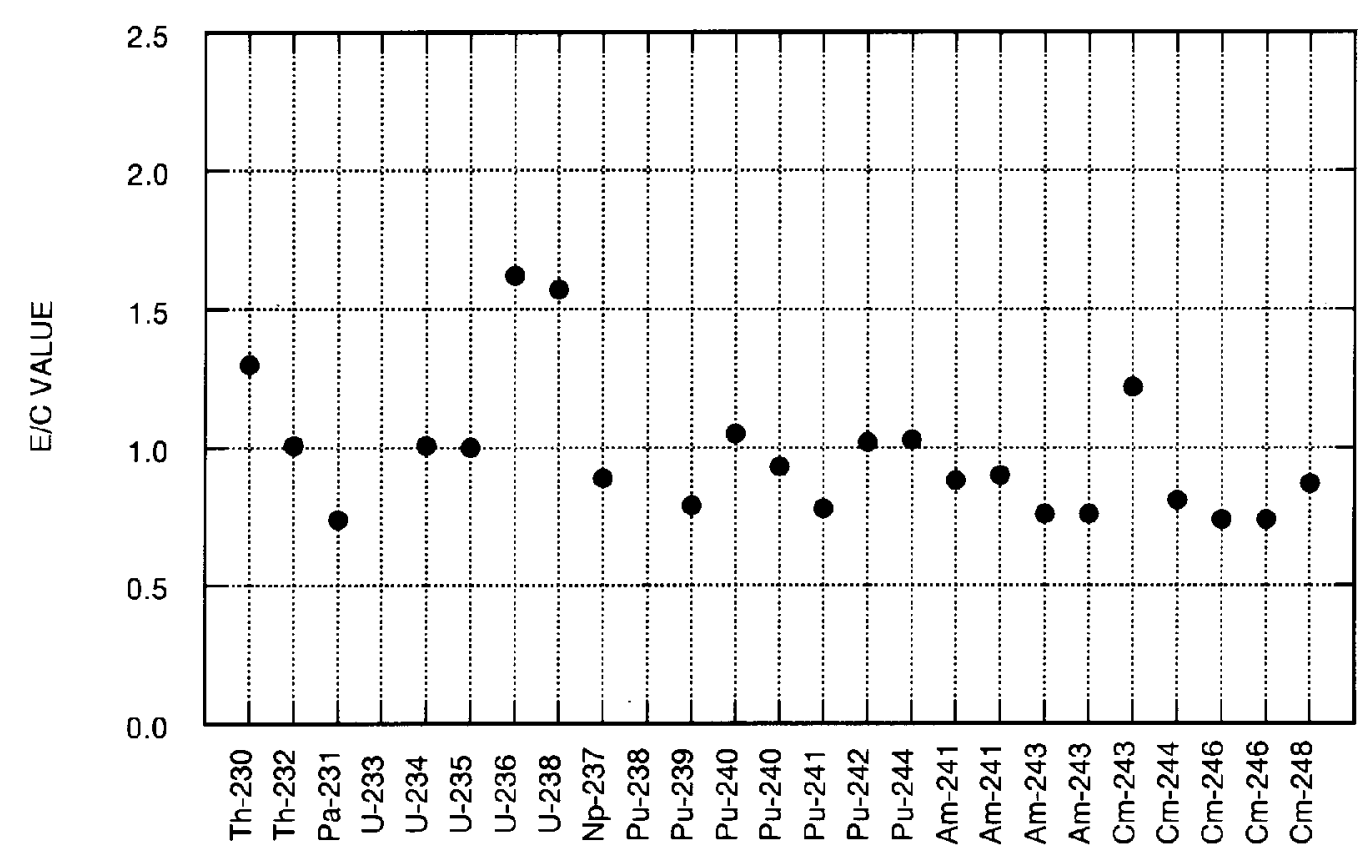

Fig. 12. E/C values for the ${ }^{144} \mathrm{Ce}$ concentration in the actinide samples.

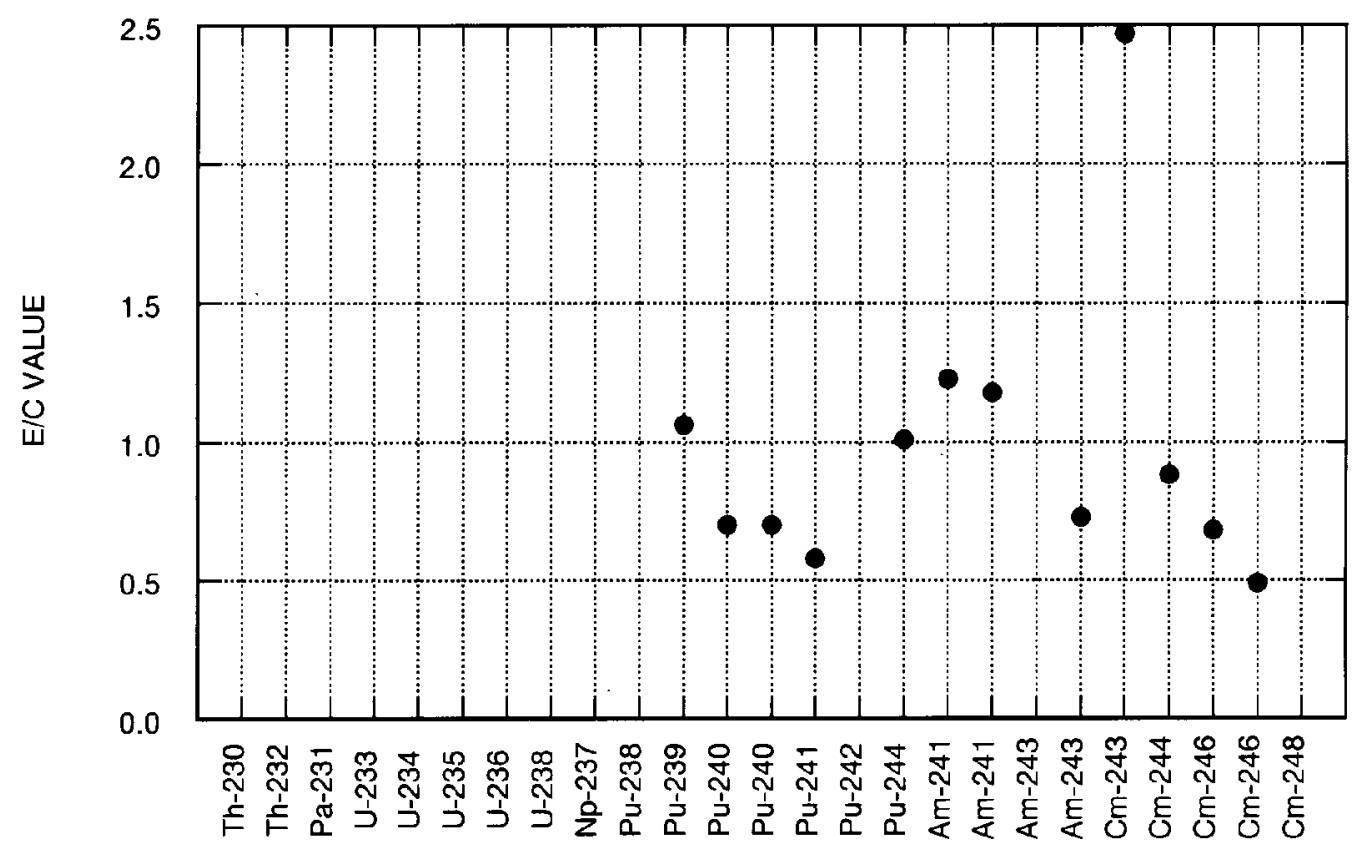

Fig. 13. E/C values for the ${ }^{152} \mathrm{Eu}$ concentration in the actinide samples. Data were not available for some of the samples. Furthermore, an E/C value of 6.41 was determined for ${ }^{242} \mathrm{Pu}$ but it has not been plotted. 


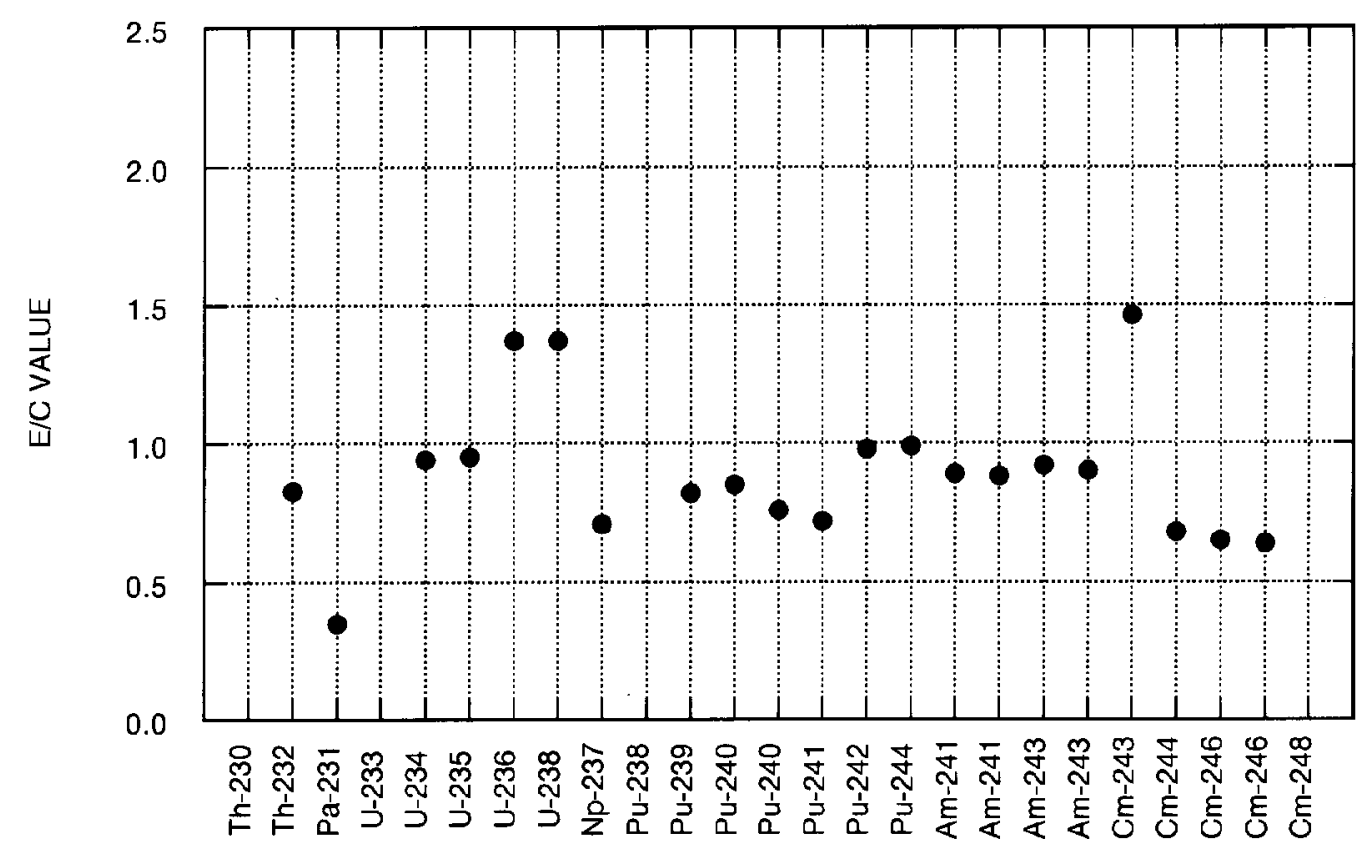

Fig. 14. E/C values for the ${ }^{154} \mathrm{Eu}$ concentration in the actinide samples.

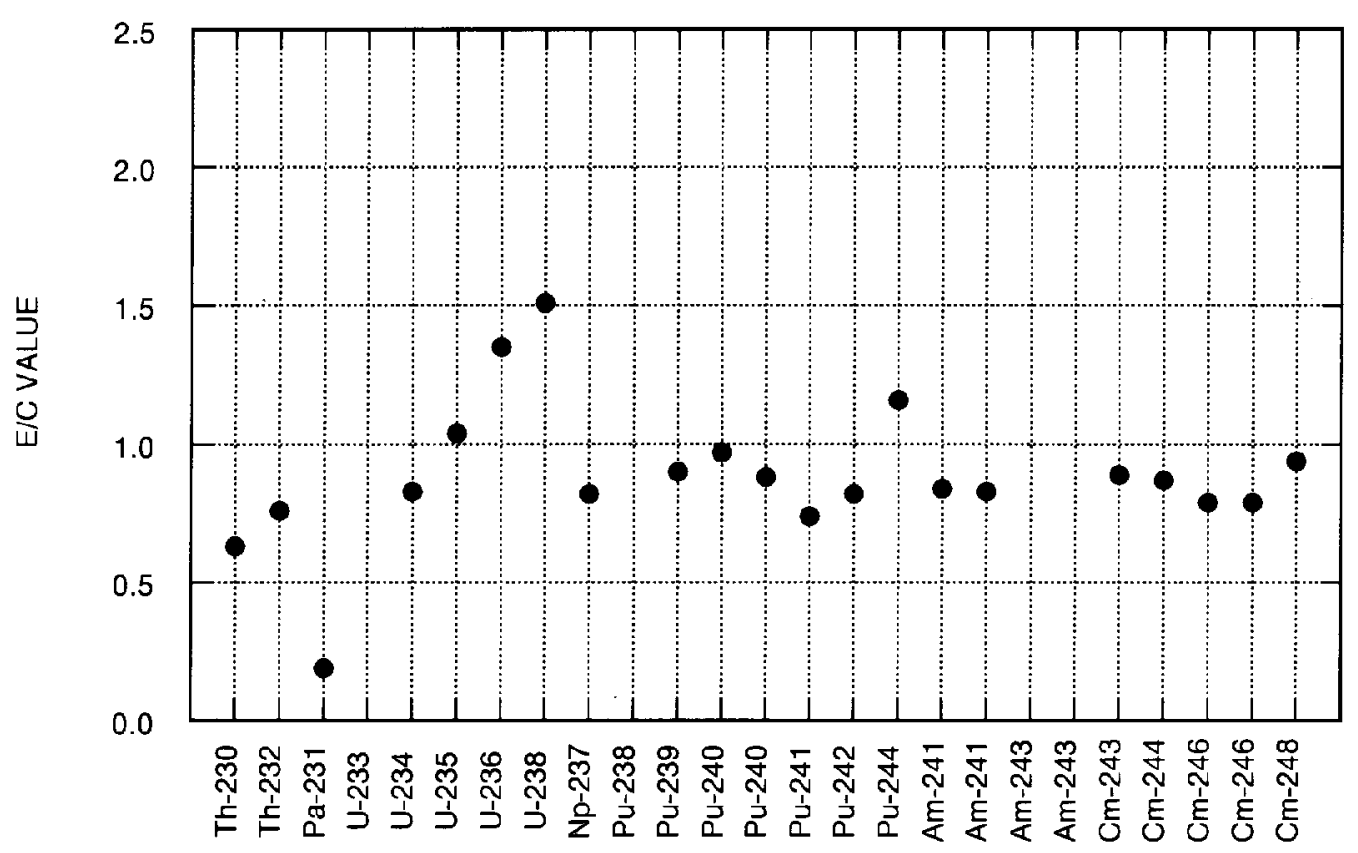

Fig. 15. E/C values for the ${ }^{155} \mathrm{Eu}$ concentration in the actinide samples. The $\mathrm{E} / \mathrm{C}$ values for the two ${ }^{243} \mathrm{Am}$ samples were determined to be 3.04 and 3.58. They are not shown on the plot. 


\section{SUMMARY AND CONCLUSIONS}

This report has presented details from the post-irradiation analysis of the FP-4 samples. It also addresses the agreement between the simulations and the laboratory measurements, and thereby begins to develop conclusions as to the adequacy of the cross-section and fission-yield data that were used. These discussions have also documented the history of the FP-4 samples giving details of any problems encountered and of adjustments made to particular samples. Further work in this area must look at these results in more detail, and this report is intended as a reference point for such efforts.

\subsection{SUMMARY DISCUSSION OF SAMPLES}

The results of the PFR irradiation experiment are discussed below for each sample in a summary manner. Our purpose here is to indicate the extent to which conclusions can be drawn from the samples and thereby, among other things, to identify those instances where it seems likely that new insight can be gained about cross sections or fission yields. Again, samples are identified both by principal actinide and sample number.

${ }^{230} \mathrm{Th}$ (31): Burnup was small and the sample was only of moderate size. The fission cross section is particularly low. In the case of the fission products, ${ }^{232} \mathrm{Th}$ fission yields were used.

${ }^{232} \mathrm{Th}$ (25): Again, cross sections are low. The results seem reasonable.

${ }^{231} \mathrm{~Pa}$ (29): There are low E/C values for the primary actinide and for the one-neutron capture product. In turn, the amount of primary actinide depleted shows a high $\mathrm{E} / \mathrm{C}$ value. These facts, when combined with low E/C values for the fission products, would seem to indicate loss (or incomplete dissolution) of final sample material.

${ }^{234} \mathrm{U}$ (27): The actinide results for this sample show uniform and somewhat high E/C values. The E/C values for ${ }^{234} \mathrm{U},{ }^{235} \mathrm{U}$, and ${ }^{236} \mathrm{U}$ are $1.19,1.19$, and 1.22 , respectively.

${ }^{235} \mathrm{U}(28)$ : The final amount and the amount of the burn for the principal actinide, together with the one-neutron capture product show good E/C values. The fission-product results are surprising with both cesium isotopes showing low $\mathrm{E} / \mathrm{C}$ values.

${ }^{236} \mathrm{U}$ (26): This sample required an adjustment factor of 1.96 (the ${ }^{235} \mathrm{U}$ component was used for adjustment), and one must be cautious in interpreting all results.

${ }^{238} \mathrm{U}(11)$ : In this case there was very significant loss of final sample material (adjustment factor of 4.8). Via the ${ }^{235} U$ content (which was, however, only about $0.03 \%$ ), an adjustment was made. All results should be viewed with caution for this sample.

${ }^{237} \mathrm{~Np}(7)$ : The results for this sample are reasonable if not particularly outstanding. 
${ }^{239} \mathrm{Pu}$ (23): This sample was adjusted because material loss had occurred. The adjustment was effected via the ${ }^{239} \mathrm{Pu}$ dosimeters. The fission-product results were obtained from a measurement on the reduced sample and were adjusted accordingly. The fission-product results seem reasonable.

${ }^{240} \mathrm{Pu}$ (21 and 22): Results from both samples should probably be averaged. The variation between the samples is indicative of the measurement uncertainty. Fission-product results are consistent for the two samples.

${ }^{241} \mathrm{Pu}$ (24): All E/C values are low for the actinides (with E/C for the amount of ${ }^{241} \mathrm{Pu}$ burned being slightly high). Similarly, the fission products show low $\mathrm{E} / \mathrm{C}$ values. One could conclude that there has been some loss or incomplete dissolution of final sample material.

${ }^{242} \mathrm{Pu}$ (16): This sample required significant adjustment (a factor of 2.49). The results for this sample are uncertain.

${ }^{244} \mathrm{Pu}$ (20): The actinide results seem reasonable. The fission-product results also seem reasonable.

${ }^{241} \mathrm{Am}$ (14 and 15): The two samples give essentially the same results. The results for ${ }^{241} \mathrm{Am}$, ${ }^{242 \mathrm{~m}} \mathrm{Am},{ }^{243} \mathrm{Am},{ }^{242} \mathrm{Pu}$, and ${ }^{238} \mathrm{Pu}$ are all consistent for both samples. Fission-product results are also consistent.

${ }^{243} \mathrm{Am}$ (12 and 13): Both samples give consistent results. The actinide results show good predictability. When these samples were prepared, it was determined that they contained activity due to ${ }^{239} \mathrm{Pu}$ and/or ${ }^{240} \mathrm{Pu}$, but it was not possible to determine how much of each. Our simulations assumed that all of this activity was due to ${ }^{240} \mathrm{Pu}$. This assumption gave the best overall agreement with the measurements. uncertainty.

${ }^{243} \mathrm{Cm}$ (10): This sample was quite small and all results are probably subject to significant

${ }^{244} \mathrm{Cm}$ (9): The principal actinide results from this sample are encouraging. Fission-product $\mathrm{E} / \mathrm{C}$ values are low, as are others in this region.

${ }^{246} \mathrm{Cm}$ (5 and 6): The variations between these two samples are indicative of the measurement uncertainty. It is possible to use the ${ }^{244} \mathrm{Cm}$ content of these samples for renormalization. The effect of such a renormalization is very similar to averaging the results from both samples.

${ }^{248} \mathrm{Cm}$ (4): Results from this sample are mixed. However, the ${ }^{244} \mathrm{Cm}$ result in this sample is good. This boosts our confidence in the data from the ${ }^{244} \mathrm{Cm}$ sample itself. As with all of the curium isotopes, the fission products yield $\mathrm{E} / \mathrm{C}$ values that are somewhat low. 


\section{REFERENCES}

1. R. L. Walker, J. L. Botts, R. J. Hydzik, J. M. Keller, J. K. Dickens, and S. Raman, Analytical Results of Physics Specimens and Dosimeters in Fuel Pins 1, 2, and 4 Irradiated in the Dounreay Prototype Fast Reactor, ORNL-6837, Martin Marietta Energy Systems, Oak Ridge Natl. Lab., December 1994.

2. O. W. Hermann and R. M. Westfall, "ORIGEN-S: SCALE System Module to Calculate Fuel Depletion, Actinide Transmutation, Fission Product Buildup and Decay, and Associated Radiation Source Terms," Sect. F7 of ORNL/NUREG/CSD-2/V2/R4, SCALE: A Modular Code System for Performing Standardized Computer Analyses for Licensing Evaluation, NUREG/CR-0200, Rev. 4 (ORNL/NUREG/CSD-2/R4), Vols. I, II and III (April 1995). Available from Radiation Shielding Information Center as CCC-545 .

3. "ENDF/B-V Summary Documentation," Compiled by R. Kinsey, Brookhaven National Laboratory, BNL-NCS-17541 [ENDF-201], 3rd Edition, July 1979. Note that this publication does not contain summary information on all actinides mentioned in this report. More complete summary information is available in the header data attached to the ENDF files themselves.

4. "ENDF/B-VI Summary Documentation," Compiled and Edited by P. F. Rose, Brookhaven National Laboratory, BNL-NCS-17541 [ENDF-201], 4th Edition, October 1991.

5. S. Raman, B. D. Murphy, C. W. Nestor, Jr., C. C. Foreman, W. S. Fraser, and T. D. Newton, Dounreay PFR Irradiation History for the US/UK Actinide Sample Exposures, ORNL/TM12984, Martin Marietta Energy Systems, Inc., Oak Ridge Natl. Lab., July 1995.

6. N. M. Greene, J. W. Arwood, R. Q. Wright, and C. V. Parks, The LAW Library - A Multigroup Cross-Section Library for Use in Radioactive Waste Analysis Calculations, ORNL/TM-12370, Martin Marietta Energy Systems, Inc., Oak Ridge Natl. Lab., August 1994.

7. M. J. Bell, ORIGEN - The ORNL Isotope Generation and Depletion Code, ORNL-4628, Union Carbide Corp., Nucl. Div., Oak Ridge Natl. Lab., May 1973.

8. G. W. Morrison, C. R. Weisbin, and C. W. Kee, "Decay Heat Analysis for an LMFBR Fuel Assembly Using ENDF/B-IV Data," Proceedings, Nuclear Cross Sections and Technology, Washington, D.C. March 3-7, 1975, NBS Special Publication 425, vol. 1, U.S. Dept. of Commerce, National Bureau of Standards (Oct. 1975).

9. K. Gunji of Japan Atomic Energy Research Institute (JAERI), personal communication to S. Raman, Oak Ridge National Laboratory, 1994.

10. J. L. Rowlands, C. J. Dean, J. D. MacDougall, and R. W, Smith, "The Production and Performance of the Adjusted Cross-Section Set FGL5," p. 1133 in Proc. Int. Symp. in Physics of Fast Reactors, Tokyo, Japan, 1973. 


\section{APPENDIX A}

\section{NUCLIDES IN THE LAW LIBRARY}

The nuclides contained in the LAW library are shown in Table A.1. The table also contains some further information on the cross-section data for these nuclei. The explanations that follow are from Greene et al. ${ }^{6}$ and are helpful in understanding the entries in Table A.1. In following the explanations below, one should have a rudimentary knowledge of the ENDF system. ${ }^{3,4}$ However, the data that are of most importance (i.e., the nuclide and the evaluation data) need little explanation. For a more detailed understanding of the LAW library, one should consult the report cited. ${ }^{6}$

In Table A.1, the common ZA (atomic number Z, atomic mass A) notation is used to identify cross-section sets, whenever possible. Nuclides with MAT-numbers (the ENDF/B nuclide identifier) in the 1000 range were taken from the General-Purpose file, while those from the Actinide File are in the 8000 range, and those from the Fission Product File are in the 9000 range. The "MOD" is the revision number for the set of data; the "DATE" is the evaluation date. The notation under "RESONANCE DATA" tells what kind of resonance data, if any, are contained in the ENDF file. For example, "SL17" indicates that the evaluation contains 17 single-level Breit-Wigner resonances, "ML17" 17 multilevel Breit-Wigner resonances, and "UN" unresolved resonance data. In the case of ${ }^{233} \mathrm{U}$ and ${ }^{241} \mathrm{Pu}$, "AA" indicates the evaluation uses the Adler-Adler formalism. A notation "BF" implies this nuclide has Bondarenko factors for all energy groups. 
Table A.1. Contents of 238-group LAW library

\begin{tabular}{|c|c|c|c|c|c|c|}
\hline Nuclide & $\begin{array}{c}\text { LAW } \\
\text { identifier }\end{array}$ & $\begin{array}{l}\text { ENDF } \\
\text { MAT }\end{array}$ & MOD & $\begin{array}{l}\text { Eval. } \\
\text { date }\end{array}$ & $\begin{array}{l}\text { Resonance } \\
\text { data }\end{array}$ & $\begin{array}{c}\text { Thermal } \\
\text { MAT }\end{array}$ \\
\hline 47-Ag-107 & 47107 & 1407 & 2 & Jun 1983 & ML74 & \\
\hline 47-Ag-109 & 47109 & 1409 & 2 & Jun 1983 & ML83 & \\
\hline 47-Ag-111 & 47111 & 9415 & 1 & Dec 1979 & & \\
\hline $13-\mathrm{Al}-27$ & 13027 & 1313 & 1 & Dec 1973 & $\mathrm{BF}$ & \\
\hline 95-Am-241 & 95241 & 1361 & 2 & Apr 1978 & SL66,UN & \\
\hline 95-Am-242 & 95242 & 8542 & 1 & Aug 1975 & SL82,UN & \\
\hline 95-Am-242m & 95601 & 1369 & 1 & Apr 1978 & SL6,UN & \\
\hline 95-Am-243 & 95243 & 1363 & 2 & Apr 1978 & & \\
\hline 33-As-75 & 33075 & 9071 & 1 & Apr 1974 & SL220,UN & \\
\hline 79-Au-197 & 79197 & 1379 & 3 & Feb 1977 & SL32 & \\
\hline $5-B-10$ & 5010 & 1305 & 1 & Dec 1976 & ML263 & \\
\hline $5-B-11$ & 5011 & 1160 & 1 & Sep 1971 & & \\
\hline 56-Ba-134 & 56134 & 9684 & 1 & Apr 1974 & & \\
\hline 56-Ba-135 & 56135 & 9685 & 1 & Apr 1974 & SL8 & \\
\hline 56-Ba-136 & 56136 & 9687 & 1 & Apr 1974 & SL13 & \\
\hline 56-Ba-137 & 56137 & 9689 & 1 & Apr 1974 & SL3 & \\
\hline 56-Ba-138 & 56138 & 1353 & 1 & Aug 1978 & SL8 & \\
\hline 56-Ba-140 & 56140 & 9693 & 1 & Dec 1979 & & \\
\hline 4-Be-9 & 4009 & 1304 & 2 & Oct 1976 & & \\
\hline Be-metal & 4309 & 1304 & 2 & & & 1064 \\
\hline 83-Bi-209 & 83209 & 1375 & 1 & Apr 1980 & & \\
\hline 97-Bk-249 & 97249 & 8749 & 1 & Jul 1976 & & \\
\hline 35-Br-79 & 35079 & 9113 & 1 & Apr 1974 & SL91,UN & \\
\hline $35-\mathrm{Br}-81$ & 35081 & 9117 & 1 & Apr 1974 & SL13 & \\
\hline $6-C$ & 6012 & 1306 & 2 & Dec 1973 & SL5 & \\
\hline Graphite & 6000 & 1306 & 2 & & & 1065 \\
\hline $20-\mathrm{Ca}$ & 20000 & 1320 & 3 & Aug 1971 & & \\
\hline $48-\mathrm{Cd}$ & 48000 & 1281 & 1 & May 1974 & & \\
\hline 48-Cd-106 & 48106 & 9440 & 2 & Feb 1980 & & \\
\hline 48-Cd-108 & 48108 & 9442 & 1 & Apr 1974 & & \\
\hline 48-Cd-110 & 48110 & 9444 & 1 & Apr 1974 & & \\
\hline 48-Cd-111 & 48111 & 9445 & 1 & Apr 1974 & SL68 & \\
\hline 48-Cd-112 & 48112 & 9447 & 1 & Apr 1974 & SL125 & \\
\hline 48-Cd-113 & 48113 & 1318 & 1 & Nov 1978 & SL55 & \\
\hline 48-Cd-114 & 48114 & 9450 & 1 & Apr 1974 & SL12,UN & \\
\hline 48-Cd-115 & 48601 & 9452 & 1 & Dec 1979 & SL33 & \\
\hline 48-Cd-116 & 48116 & 9453 & 1 & Apr 1974 & & \\
\hline 58-Ce-140 & 58140 & 9724 & 1 & Apr 1974 & SL12 & \\
\hline
\end{tabular}


Table A.1 (continued)

\begin{tabular}{|c|c|c|c|c|c|c|}
\hline Nuclide & $\begin{array}{c}\text { LAW } \\
\text { identifier }\end{array}$ & $\begin{array}{l}\text { ENDF } \\
\text { MAT }\end{array}$ & MOD & $\begin{array}{l}\text { Eval. } \\
\text { date }\end{array}$ & $\begin{array}{l}\text { Resonance } \\
\text { data }\end{array}$ & $\begin{array}{c}\text { Thermal } \\
\text { MAT }\end{array}$ \\
\hline $58-\mathrm{Ce}-140$ & 58140 & 9724 & 1 & Apr 1974 & & \\
\hline $58-\mathrm{Ce}-141$ & 58141 & 9725 & 1 & Dec 1979 & & \\
\hline $58-\mathrm{Ce}-142$ & 58142 & 9726 & 1 & Apr 1974 & & \\
\hline $58-\mathrm{Ce}-143$ & 58143 & 9727 & 1 & Dec 1979 & & \\
\hline $58-\mathrm{Ce}-144$ & 58144 & 9728 & 1 & Dec 1979 & & \\
\hline 98-Cf-249 & 98249 & 8849 & 1 & Jul 1976 & SL53,UN & \\
\hline 98-Cf-250 & 98250 & 8850 & 1 & Jul 1976 & SL20,UN & \\
\hline 98-Cf-251 & 98251 & 8851 & 1 & Jul 1976 & SL20,UN & \\
\hline 98-Cf-252 & 98252 & 8852 & 1 & Jul 1976 & SL21,UN & \\
\hline 98-Cf-253 & 98253 & 8853 & 1 & Dec 1975 & SL120,UN & \\
\hline $17-\mathrm{Cl}$ & 17000 & 1149 & 1 & Feb 1967 & & \\
\hline 96-Cm-241 & 96241 & 8641 & 1 & Apr 1978 & & \\
\hline $96-\mathrm{Cm}-242$ & 96242 & 8642 & 1 & Apr 1978 & SL21,UN & \\
\hline $96-\mathrm{Cm}-243$ & 96243 & 1343 & 1 & Apr 1978 & SL16,UN & \\
\hline 96-Cm-244 & 96244 & 1344 & 2 & Apr 1978 & SL38,UN & \\
\hline $96-\mathrm{Cm}-245$ & 96245 & 1345 & 2 & Jan 1979 & SL39,UN & \\
\hline $96-\mathrm{Cm}-246$ & 96246 & 1346 & 1 & Jul 1976 & SL10,UN & \\
\hline 96-Cm-247 & 96247 & 8647 & 1 & Jul 1976 & SL35,UN & \\
\hline $96-\mathrm{Cm}-248$ & 96248 & 8648 & 1 & Apr 1978 & SL46,UN & \\
\hline 27-Сo-59 & 27059 & 1327 & 3 & Jun 1977 & ML180 & \\
\hline $24-\mathrm{Cr}$ & 24000 & 1324 & 2 & Dec 1977 & SL183 & \\
\hline $24-\mathrm{Cr}\left(1 / \mathrm{E}^{*} \mathrm{~F}_{t}\right)$ & 24301 & 1324 & 2 & Dec 1977 & SL183 & \\
\hline $24-\mathrm{Cr}\left(1 / \mathrm{E}^{*} \mathrm{~F}_{\mathrm{t}}(\mathrm{SS} 304)\right)$ & 24304 & 1324 & 2 & Dec 1977 & SL183 & \\
\hline $55-\mathrm{Cs}-133$ & 55133 & 1355 & 1 & Nov 1978 & SL123 & \\
\hline $55-C s-134$ & 55134 & 9663 & 1 & Dec 1979 & & \\
\hline 55-Cs-135 & 55135 & 9665 & 1 & Dec 1979 & & \\
\hline $55-\mathrm{Cs}-136$ & 55136 & 9667 & 1 & Dec 1979 & SL7 & \\
\hline $55-\mathrm{Cs}-137$ & 55137 & 9669 & 1 & Dec 1979 & & \\
\hline $29-\mathrm{Cu}$ & 29000 & 1329 & 1 & Dec 1973 & ML48 & \\
\hline $1-\mathrm{D}-2$ & 1802 & 1302 & 2 & Nov 1967 & & \\
\hline Deuterium & 1002 & 1302 & 2 & & & 1004 \\
\hline 66-Dy-160 & 66160 & 9864 & 1 & Apr 1974 & SL3 & \\
\hline 66-Dy-161 & 66161 & 9865 & 1 & Apr 1974 & SL27 & \\
\hline 66-Dy-162 & 66162 & 9866 & 1 & Apr 1974 & SL8 & \\
\hline 66-Dy-163 & 66163 & 9867 & 1 & Apr 1974 & SL60 & \\
\hline 66-Dy-164 & 66164 & 1031 & 1 & Jun 1967 & SL2,UN & \\
\hline 68-Er-166 & 68166 & 9875 & 1 & Apr 1974 & SL51 & \\
\hline 68-Er-167 & 68167 & 9876 & 1 & Apr 1974 & SL32 & \\
\hline
\end{tabular}


Table A.1 (continued)

\begin{tabular}{|c|c|c|c|c|c|c|}
\hline Nuclide & $\begin{array}{c}\text { LAW } \\
\text { identifier }\end{array}$ & $\begin{array}{l}\text { ENDF } \\
\text { MAT }\end{array}$ & MOD & $\begin{array}{l}\text { Eval. } \\
\text { date }\end{array}$ & $\begin{array}{l}\text { Resonance } \\
\text { data }\end{array}$ & $\begin{array}{c}\text { Thermal } \\
\text { MAT }\end{array}$ \\
\hline 99-Es-253 & 99253 & 8953 & 1 & Jul 1976 & SL27,UN & \\
\hline 63-Eu & 63000 & 1463 & 1 & Aug 1981 & ML164 & \\
\hline 63-Eu-151 & 63151 & 1357 & 1 & Dec 1977 & SL92,UN & \\
\hline 63-Eu-152 & 63152 & 1292 & 2 & Dec 1973 & SL93,UN & \\
\hline 63-Eu-153 & 63153 & 1359 & 1 & Feb 1978 & ML72,UN & \\
\hline 63-Eu-154 & 63154 & \multicolumn{5}{|c|}{ Version 6 of ENDF/B } \\
\hline 63-Eu-154 & 631541 & 1293 & 1 & Dec 1973 & SL72,UN & \\
\hline 63-Eu-155 & 63155 & \multicolumn{5}{|c|}{ Version 6 of ENDF/B } \\
\hline 63-Eu-155 & 631551 & 9832 & 1 & Dec 1979 & & \\
\hline 63-Eu-156 & 63156 & 9833 & 1 & Dec 1979 & & \\
\hline 63-Eu-157 & 63157 & 9834 & 1 & Feb 1980 & & \\
\hline 9-F-19 & 9019 & 1309 & 3 & Jul 1974 & $\mathrm{BF}$ & \\
\hline $26-\mathrm{Fe}$ & 26000 & 1326 & 3 & Oct 1977 & ML314 & \\
\hline $26-\mathrm{Fe}\left(1 / \mathrm{E}^{*} \mathrm{~F}_{\mathrm{t}}\right)$ & 26301 & 1326 & 3 & Oct 1977 & ML314 & \\
\hline $26-\mathrm{Fe}\left(1 / \mathrm{E}^{*} \mathrm{~F}_{\mathrm{t}}(\mathrm{SS} 304)\right)$ & 26301 & 1326 & 3 & Oct 1977 & ML314 & \\
\hline 31-Ga-11 & 31000 & 1358 & 1 & May 1980 & & \\
\hline 64-Gd-152 & 64152 & 1362 & 2 & Jan 1977 & ML18 & \\
\hline 64-Gd-154 & 64154 & 1364 & 1 & Jan 1977 & ML49 & \\
\hline 64-Gd-155 & 64155 & 1365 & 1 & Jan 1977 & ML92 & \\
\hline 64-Gd-156 & 64156 & 1366 & 2 & Jan 1977 & ML30,UN & \\
\hline 64-Gd-157 & 64157 & 1367 & 1 & Jan 1977 & ML56 & \\
\hline 64-Gd-158 & 64158 & 1368 & 1 & Jan 1977 & ML93,UN & \\
\hline 64-Gd-160 & 64160 & 1370 & 1 & Jan 1977 & ML44 & \\
\hline 32-Ge-72 & 32072 & 9050 & 1 & Apr 1974 & SL8 & \\
\hline 32-Ge-73 & 32073 & 9051 & 1 & Apr 1974 & SL10 & \\
\hline 32-Ge-74 & 32074 & 9053 & 1 & Apr 1974 & SL3 & \\
\hline 32-Ge-76 & 32076 & 9056 & 1 & Apr 1974 & SL4 & \\
\hline $1-\mathrm{H}-1$ & 1801 & 1301 & 1 & Aug 1970 & & \\
\hline $\mathrm{H}$ in $\mathrm{C} 6 \mathrm{H} 6$ & 1901 & 1301 & 1 & & & 1095 \\
\hline $\mathrm{H}$ in $\mathrm{CH} 2$ & 2801 & 1301 & 1 & & & 1114 \\
\hline $\mathrm{H}$ in $\mathrm{H} 2 \mathrm{O}$ & 1001 & 1301 & 1 & & & 1002 \\
\hline $1-\mathrm{H}-3$ & 1003 & 1169 & 2 & Feb 1965 & & \\
\hline 2-He-3 & 2003 & 1146 & 1 & Jun 1968 & & \\
\hline 2-He-4 & 2004 & 1270 & 0 & Oct 1973 & & \\
\hline 72-Hf & 72000 & 1372 & 1 & Apr 1976 & SL236 & \\
\hline 72-Hf-174 & 72174 & 1374 & 1 & Apr 1976 & SL10,UN & \\
\hline 72-Hf-176 & 72176 & 1376 & 1 & Apr 1976 & SL22,UN & \\
\hline 72-Hf-177 & 72177 & 1377 & 1 & Apr 1976 & SL99,UN & \\
\hline 72-Hf-178 & 72178 & 1378 & 1 & Apr 1976 & SL25,UN & \\
\hline 72-Hf-179 & 72179 & 1383 & 1 & Apr 1976 & SL49,UN & \\
\hline
\end{tabular}


Table A.1 (continued)

\begin{tabular}{|c|c|c|c|c|c|c|}
\hline Nuclide & $\begin{array}{c}\text { LAW } \\
\text { identifier }\end{array}$ & $\begin{array}{l}\text { ENDF } \\
\text { MAT }\end{array}$ & MOD & $\begin{array}{l}\text { Eval. } \\
\text { date }\end{array}$ & $\begin{array}{l}\text { Resonance } \\
\text { data }\end{array}$ & $\begin{array}{c}\text { Thermal } \\
\text { MAT }\end{array}$ \\
\hline 72-Hf-180 & 72180 & 1384 & 1 & Apr 1976 & SL31,UN & \\
\hline 67-Нo-165 & 67165 & 9872 & 1 & Apr 1974 & SL29 & \\
\hline 53-I-127 & 53127 & 9606 & 1 & Feb 1980 & SL79 & \\
\hline 53-I-129 & 53129 & 9608 & 1 & Feb 1980 & SL5 & \\
\hline 53-I-130 & 53130 & 9609 & 1 & Dec 1979 & & \\
\hline 53-I-131 & 53131 & 9611 & 1 & Dec 1979 & & \\
\hline 53-I-135 & 53135 & 9618 & 1 & Dec 1979 & & \\
\hline 49-In-113 & 49113 & 9473 & 1 & Apr 1974 & SL9 & \\
\hline 49-In-115 & 49115 & 9477 & 1 & Dec 1979 & SL91 & \\
\hline $19-K$ & 19000 & 1150 & 1 & Feb 1967 & & \\
\hline $36-\mathrm{Kr}-78$ & 36078 & 1330 & 1 & Apr 1978 & SL4 & \\
\hline $36-\mathrm{Kr}-80$ & 36080 & 1331 & 1 & Apr 1978 & SL5 & \\
\hline $36-\mathrm{Kr}-82$ & 36082 & 1332 & 1 & Apr 1978 & SL2 & \\
\hline $36-\mathrm{Kr}-83$ & 36083 & 1333 & 1 & Apr 1978 & SL3 & \\
\hline $36-\mathrm{Kr}-84$ & 36084 & 1334 & 1 & Apr 1978 & SL3 & \\
\hline $36-\mathrm{Kr}-85$ & 36085 & 9145 & 1 & Dec 1979 & & \\
\hline 36-Kr-86 & 36086 & 1336 & 1 & Jul 1972 & SL1 & \\
\hline 57-La-139 & 57139 & 9707 & 1 & Feb 1980 & SL69 & \\
\hline 57-La-140 & 57140 & 9708 & 1 & Dec 1979 & & \\
\hline 3-Li-6 & 3006 & 1303 & 1 & Sep 1977 & & \\
\hline 3-Li-7 & 3007 & 1397 & 1 & Dec 1981 & $\mathrm{BF}$ & \\
\hline 71-Lu-175 & 71175 & 1032 & 1 & Jun 1967 & SL17,UN & \\
\hline 71-Lu-176 & 71176 & 1033 & 1 & Jun 1967 & SL21,UN & \\
\hline 12-Mg & 12000 & 1312 & 1 & Feb 1978 & & \\
\hline 25-Mn-55 & 25055 & 1325 & 2 & Mar 1977 & ML141 & \\
\hline 42-Мo & 42000 & 1321 & 1 & Feb 1979 & SL46 & \\
\hline 42-Мo-92 & 42092 & 9278 & 1 & Feb 1980 & SL28 & \\
\hline 42-Мo-94 & 42094 & 9281 & 1 & Feb 1980 & SL10 & \\
\hline 42-Mo-95 & 42095 & 9282 & 1 & Feb 1980 & SL55 & \\
\hline 42-Mo-96 & 42096 & 9283 & 1 & Feb 1980 & SL15 & \\
\hline 42-Mo-97 & 42097 & 9284 & 1 & Feb 1980 & SL64 & \\
\hline 42-Мo-98 & 42098 & 9285 & 1 & Feb 1980 & SL22 & \\
\hline 42-Мo-99 & 42099 & 9286 & 1 & Dec 1979 & & \\
\hline 42-Mo-100 & 42100 & 9287 & 1 & Feb 1980 & SL17 & \\
\hline $7-\mathrm{N}-14$ & 70141 & 1275 & 2 & Jul 1973 & & \\
\hline $7-\mathrm{N}-14$ & 7014 & \multicolumn{5}{|c|}{ Version 6 of ENDF/B } \\
\hline $7-\mathrm{N}-15$ & 70151 & 1307 & 1 & Mar 1977 & & \\
\hline $7-\mathrm{N}-15$ & 7015 & \multicolumn{5}{|c|}{ Version 6 of ENDF/B } \\
\hline
\end{tabular}


Table A.1 (continued)

\begin{tabular}{|c|c|c|c|c|c|c|}
\hline Nuclide & $\begin{array}{c}\text { LAW } \\
\text { identifier }\end{array}$ & $\begin{array}{c}\text { ENDF } \\
\text { MAT }\end{array}$ & MOD & $\begin{array}{l}\text { Eval. } \\
\text { date }\end{array}$ & $\begin{array}{c}\text { Resonance } \\
\text { data }\end{array}$ & $\begin{array}{c}\text { Thermal } \\
\text { MAT }\end{array}$ \\
\hline $11-\mathrm{Na}-23$ & 11023 & 1311 & 3 & Dec 1977 & ML23 & \\
\hline 41-Nb-93 & 41093 & 1189 & 1 & May 1974 & SL218,UN & \\
\hline 41-Nb-94 & 41094 & 9251 & 1 & Dec 1979 & SL2 & \\
\hline 41-Nb-95 & 41095 & 9253 & 1 & Dec 1979 & & \\
\hline 60-Nd-142 & 60142 & 9763 & 1 & Apr 1974 & SL17 & \\
\hline 60-Nd-143 & 60143 & 9764 & 1 & Feb 1980 & SL18 & \\
\hline 60-Nd-144 & 60144 & 9765 & 1 & Feb 1980 & SL19 & \\
\hline 60-Nd-145 & 60145 & 9766 & 1 & Feb 1980 & SL79 & \\
\hline 60-Nd-146 & 60146 & 9767 & 1 & Feb 1980 & SL18 & \\
\hline 60-Nd-147 & 60147 & 9768 & 1 & Dec 1979 & & \\
\hline 60-Nd-148 & 60148 & 9769 & 1 & Feb 1980 & SL12 & \\
\hline 60-Nd-150 & 60150 & 9771 & 1 & Feb 1980 & SL15 & \\
\hline $28-\mathrm{Ni}$ & 28000 & 1328 & 2 & Mar 1977 & SL294 & \\
\hline $28-\mathrm{Ni}\left(1 / \mathrm{E}^{*} \mathrm{~F}_{\mathrm{t}}\right)$ & 28301 & 1328 & 2 & Mar 1977 & SL294 & \\
\hline $28-\mathrm{Ni}\left(1 / \mathrm{E}^{*} \mathrm{~F}_{\mathrm{t}}(\mathrm{SS} 304)\right)$ & 28304 & 1328 & 2 & Mar 1977 & SL294 & \\
\hline $93-\mathrm{Np}-237$ & 93237 & 1337 & 2 & Apr 1978 & SL169,UN & \\
\hline 93-Np-238 & 93238 & 8338 & 1 & Aug 1975 & SL95,UN & \\
\hline $8-0-16$ & 80161 & 1276 & 2 & Aug 1973 & & \\
\hline $8-0-16$ & 8016 & \multicolumn{5}{|c|}{ Version 6 of ENDF/B } \\
\hline $8-\mathrm{O}-17$ & 8017 & 1317 & 1 & Jan 1978 & & \\
\hline 15-P-31 & 15031 & 1315 & 1 & Oct 1977 & & \\
\hline 91-Pa-231 & 91231 & 8131 & 1 & Nov 1977 & SL31,UN & \\
\hline 91-Pa-233 & 91233 & 1391 & 2 & May 1978 & SL34,UN & \\
\hline $82-\mathrm{Pb}$ & 82000 & 1382 & 2 & Jul 1971 & & \\
\hline 46-Pd-102 & 46102 & 9379 & 2 & Feb 1980 & & \\
\hline 46-Pd-104 & 46104 & 9381 & 1 & Feb 1980 & SL1 & \\
\hline 46-Pd-105 & 46105 & 9382 & 1 & Feb 1980 & SL9 & \\
\hline 46-Pd-106 & 46106 & 9383 & 1 & Feb 1980 & SL1 & \\
\hline 46-Pd-107 & 46107 & 9384 & 1 & Feb 1980 & & \\
\hline 46-Pd-108 & 46108 & 9386 & 1 & Feb 1980 & SL3 & \\
\hline 46-Pd-110 & 46110 & 9389 & 1 & Feb 1980 & & \\
\hline 61-Pm-147 & 61147 & 9783 & 1 & Feb 1980 & SL14 & \\
\hline 61-Pm-148 & 61148 & 9784 & 1 & Dec 1979 & & \\
\hline 61-Pm-148m & 61601 & 9785 & 1 & Dec 1979 & SL1 & \\
\hline 61-Pm-149 & 61149 & 9786 & 1 & Dec 1979 & & \\
\hline 61-Pm-151 & 61151 & 9788 & 1 & Dec 1979 & & \\
\hline
\end{tabular}


Table A.1 (continued)

\begin{tabular}{|c|c|c|c|c|c|c|}
\hline Nuclide & $\begin{array}{c}\text { LAW } \\
\text { identifier }\end{array}$ & $\begin{array}{l}\text { ENDF } \\
\text { MAT }\end{array}$ & MOD & $\begin{array}{l}\text { Eval. } \\
\text { date }\end{array}$ & $\begin{array}{l}\text { Resonance } \\
\text { data }\end{array}$ & $\begin{array}{c}\text { Thermal } \\
\text { MAT }\end{array}$ \\
\hline 59-Pr-141 & 59141 & 9742 & 1 & Feb 1980 & SL15 & \\
\hline 59-Pr-142 & 59142 & 9743 & 1 & Dec 1979 & & \\
\hline 59-Pr-143 & 59143 & 9745 & 1 & Dec 1979 & & \\
\hline 94-Pu-236 & 94236 & 8436 & 1 & Apr 1978 & SL21,UN & \\
\hline 94-Pu-237 & 94237 & 8437 & 1 & Apr 1978 & & \\
\hline 94-Pu-238 & 94238 & 1338 & 3 & Apr 1978 & SL16,UN & \\
\hline 94-Pu-239 & 94239 & 1399 & 2 & & SL128,UN & \\
\hline 94-Pu-240 & 94240 & 1380 & 3 & Apr 1977 & ML201,UN & \\
\hline 94-Pu-241 & 94241 & 1381 & 2 & Oct 1977 & AA83,UN & \\
\hline 94-Pu-242 & 94242 & 1342 & 2 & Oct 1978 & SL68,UN & \\
\hline 94-Pu-243 & 94243 & 8443 & 1 & Jul 1976 & SL41,UN & \\
\hline 94-Pu-244 & 94244 & 8444 & 1 & Apr 1978 & SL21,UN & \\
\hline 37-Rb-85 & 37085 & 1360 & 1 & Oct 1979 & ML88 & \\
\hline 37-Rb-86 & 37086 & 9161 & 1 & Dec 1979 & & \\
\hline 37-Rb-87 & 37087 & 1341 & 1 & Oct 1979 & ML15 & \\
\hline 75-Re-185 & 75185 & 1083 & 1 & Jan 1968 & SL30,UN & \\
\hline 75-Re-187 & 75187 & 1084 & 1 & Jan 1968 & SL25,UN & \\
\hline 45-Rh-103 & 45103 & 1310 & 1 & Nov 1978 & SL119,UN & \\
\hline 45-Rh-105 & 45105 & 9355 & 2 & Dec 1979 & & \\
\hline 44-Ru-96 & 44096 & 9325 & 2 & Feb 1980 & & \\
\hline 44-Ru-98 & 44098 & 9327 & 2 & Feb 1980 & & \\
\hline 44-Ru-99 & 44099 & 9328 & 1 & Apr 1974 & SL5 & \\
\hline 44-Ru-100 & 44100 & 9329 & 1 & Feb 1980 & SL1 & \\
\hline 44-Ru-101 & 44101 & 9330 & 1 & Feb 1980 & SL7 & \\
\hline 44-Ru-102 & 44102 & 9331 & 1 & Feb 1980 & SL3 & \\
\hline 44-Ru-103 & 44103 & 9332 & 1 & Dec 1979 & & \\
\hline 44-Ru-104 & 44104 & 9333 & 1 & Feb 1980 & SL4 & \\
\hline 44-Ru-105 & 44105 & 9334 & 1 & Dec 1979 & & \\
\hline 44-Ru-106 & 44106 & 9335 & 1 & Dec 1979 & & \\
\hline $16-\mathrm{S}$ & 16000 & 1347 & 1 & Apr 1979 & ML118 & \\
\hline $16-S-32$ & 16032 & 1316 & 1 & Oct 1977 & SL82 & \\
\hline 51-Sb-121 & 51121 & 9548 & 1 & Feb 1980 & SL63 & \\
\hline 51-Sb-123 & 51123 & 9551 & 1 & Feb 1980 & & \\
\hline 51-Sb-124 & 51124 & 9552 & 1 & Dec 1979 & & \\
\hline 51-Sb-125 & 51125 & 9555 & 1 & Dec 1979 & & \\
\hline 51-Sb-126 & 51126 & 9556 & 1 & Dec 1979 & & \\
\hline
\end{tabular}


Table A.1 (continued)

\begin{tabular}{|c|c|c|c|c|c|c|}
\hline Nuclide & $\begin{array}{c}\text { LAW } \\
\text { identifier }\end{array}$ & $\begin{array}{l}\text { ENDF } \\
\text { MAT }\end{array}$ & MOD & $\begin{array}{l}\text { Eval. } \\
\text { date }\end{array}$ & $\begin{array}{l}\text { Resonance } \\
\text { data }\end{array}$ & $\begin{array}{c}\text { Thermal } \\
\text { MAT }\end{array}$ \\
\hline 34-Se-74 & 34074 & 9089 & 2 & Feb 1980 & SL7 & \\
\hline $34-\mathrm{Se}-76$ & 34076 & 9091 & 1 & Apr 1974 & SL17 & \\
\hline 34-Se-77 & 34077 & 9092 & 1 & Apr 1974 & SL31 & \\
\hline 34-Se-78 & 34078 & 9094 & 1 & Apr 1974 & SL12 & \\
\hline $34-\mathrm{Se}-80$ & 34080 & 9097 & 1 & Apr 1974 & SL7 & \\
\hline 34-Se-82 & 34082 & 9100 & 1 & Apr 1974 & SL4 & \\
\hline $14-\mathrm{Si}$ & 14000 & 1314 & 3 & Feb 1974 & $\mathrm{BF}$ & \\
\hline 62-Sm-144 & 62144 & 9803 & 2 & Feb 1980 & & \\
\hline $62-\mathrm{Sm}-147$ & 62147 & 9806 & 2 & Feb 1980 & SL59 & \\
\hline 62-Sm-148 & 62148 & 9807 & 1 & Feb 1980 & & \\
\hline 62-Sm-149 & 62149 & 1319 & 1 & Nov 1978 & ML30,UN & \\
\hline $62-\mathrm{Sm}-150$ & 62150 & 9809 & 1 & Apr 1974 & SL12 & \\
\hline 62-Sm-151 & 62151 & 9810 & 1 & Feb 1980 & SL8 & \\
\hline 62-Sm-152 & 62152 & 9811 & 1 & Feb 1980 & SL57 & \\
\hline 62-Sm-153 & 62153 & 9812 & 1 & Dec 1979 & & \\
\hline 62-Sm-154 & 62154 & 9813 & 1 & Apr 1974 & SL18 & \\
\hline 50-Sn-112 & 50112 & 9513 & 2 & Feb 1980 & SL12 & \\
\hline 50-Sn-114 & 50114 & 9516 & 2 & Feb 1980 & SL5 & \\
\hline 50-Sn-115 & 50115 & 9517 & 1 & Apr 1974 & SL3 & \\
\hline 50-Sn-116 & 50116 & 9518 & 1 & Apr 1974 & SL8 & \\
\hline 50-Sn-117 & 50117 & 9519 & 1 & Apr 1974 & SL25 & \\
\hline 50-Sn-118 & 50118 & 9521 & 1 & Apr 1974 & SL8 & \\
\hline 50-Sn-119 & 50119 & 9522 & 1 & Apr 1974 & SL10 & \\
\hline $50-\mathrm{Sn}-120$ & 50120 & 9524 & 1 & Apr 1974 & SL48 & \\
\hline 50-Sn-122 & 50122 & 9527 & 1 & Apr 1974 & SL6 & \\
\hline 50-Sn-123 & 50123 & 9528 & 1 & Dec 1979 & & \\
\hline 50-Sn-124 & 50124 & 9530 & 1 & Apr 1974 & SL5 & \\
\hline 50-Sn-125 & 50125 & 9531 & 1 & Dec 1979 & & \\
\hline 50-Sn-126 & 50126 & 9533 & 1 & Dec 1979 & & \\
\hline 38-Sr-84 & 38084 & 9179 & 2 & Feb 1980 & SL10 & \\
\hline $38-\mathrm{Sr}-86$ & 38086 & 9182 & 1 & Apr 1974 & SL24 & \\
\hline $38-\mathrm{Sr}-87$ & 38087 & 9183 & 1 & Apr 1974 & SL22 & \\
\hline $38-\mathrm{Sr}-88$ & 38088 & 9185 & 1 & Apr 1974 & SL16 & \\
\hline $38-\mathrm{Sr}-89$ & 38089 & 9186 & 1 & Dec 1979 & & \\
\hline $38-\mathrm{Sr}-90$ & 38090 & 9187 & 1 & Dec 1979 & & \\
\hline
\end{tabular}


Table A.1 (continued)

\begin{tabular}{|c|c|c|c|c|c|c|}
\hline Nuclide & $\begin{array}{c}\text { LAW } \\
\text { identifier }\end{array}$ & $\begin{array}{l}\text { ENDF } \\
\text { MAT }\end{array}$ & MOD & $\begin{array}{l}\text { Eval. } \\
\text { date }\end{array}$ & $\begin{array}{l}\text { Resonance } \\
\text { data }\end{array}$ & $\begin{array}{c}\text { Thermal } \\
\text { MAT }\end{array}$ \\
\hline 73-Тa-181 & 73181 & 1285 & 2 & Jan 1972 & ML76,UN & \\
\hline 73-Тa-182 & 73182 & 1127 & 1 & Apr 1971 & ML10,UN & \\
\hline 65-Tb-159 & 65159 & 9857 & 1 & Feb 1980 & SL23 & \\
\hline $65-\mathrm{Tb}-160$ & 65160 & 9858 & 1 & Dec 1979 & & \\
\hline 43-Тc-99 & 43099 & 1308 & 2 & Nov 1978 & SL68,UN & \\
\hline $52-\mathrm{Te}-120$ & 52120 & 9576 & 2 & Feb 1980 & & \\
\hline $52-\mathrm{Te}-122$ & 52122 & 9579 & 1 & Apr 1974 & SL22 & \\
\hline $52-\mathrm{Te}-123$ & 52123 & 9580 & 1 & Apr 1974 & SL26 & \\
\hline $52-\mathrm{Te}-124$ & 52124 & 9582 & 1 & Apr 1974 & SL36 & \\
\hline $52-\mathrm{Te}-125$ & 52125 & 9583 & 1 & Apr 1974 & SL33 & \\
\hline $52-\mathrm{Te}-126$ & 52126 & 9585 & 1 & Apr 1974 & SL21 & \\
\hline $52-\mathrm{Te}-127$ & 52601 & 9587 & 1 & Dec 1979 & & \\
\hline 52-Te-128 & 52128 & 9588 & 1 & Apr 1974 & SL9 & \\
\hline $52-\mathrm{Te}-129$ & 52611 & 9590 & 1 & Dec 1979 & & \\
\hline 52-Te-130 & 52130 & 9591 & 1 & Apr 1974 & SL22 & \\
\hline 52-Te-132 & 52132 & 9594 & 1 & Dec 1979 & & \\
\hline 90-Th-230 & 90230 & 8030 & 1 & Nov 1977 & SL22 & \\
\hline 90-Th-232 & 90232 & 1390 & 2 & Dec 1977 & ML435,UN & \\
\hline 22-Ti & 22000 & 1322 & 1 & Aug 1977 & & \\
\hline 92-U-232 & 92232 & 8232 & 1 & Nov 1977 & SL13,UN & \\
\hline 92-U-233 & 92233 & 1393 & 2 & Dec 1978 & AA83,UN & \\
\hline 92-U-234 & 92234 & 1394 & 3 & Jul 1978 & ML119,UN & \\
\hline 92-U-235 & 92235 & 1395 & 3 & Apr 1977 & SL130,UN & \\
\hline 92-U-236 & 92236 & 1396 & 3 & Jul 1978 & ML191,UN & \\
\hline 92-U-237 & 92237 & 8237 & 1 & Jul 1976 & SL27,UN & \\
\hline 92-U-238 & 92238 & 1398 & 3 & Jun 1977 & ML444,UN & \\
\hline $23-\mathrm{V}$ & 23000 & 1323 & 1 & Jan 1977 & & \\
\hline $74-W$ & 74000 & 1474 & 1 & Mar 1982 & ML197 & \\
\hline 74-W-182 & 74182 & 1475 & 2 & Dec 1980 & ML69,UN & \\
\hline 74-W-183 & 74183 & 1476 & 2 & Dec 1980 & ML50,UN & \\
\hline 74-W-184 & 74184 & 1477 & 2 & Dec 1980 & ML38,UN & \\
\hline 74-W-186 & 74186 & 1478 & 2 & Dec 1980 & ML40,UN & \\
\hline 54-Xe-124 & 54124 & 1335 & 1 & Mar 1978 & ML4 & \\
\hline $54-X e-126$ & 54126 & 1339 & 1 & Mar 1978 & ML4 & \\
\hline 54-Xe-128 & 54128 & 1348 & 1 & Mar 1978 & ML10 & \\
\hline $54-X e-129$ & 54129 & 1349 & 1 & Mar 1978 & ML70 & \\
\hline
\end{tabular}


Table A.1 (continued)

\begin{tabular}{|c|c|c|c|c|c|c|}
\hline Nuclide & $\begin{array}{c}\text { LAW } \\
\text { identifier }\end{array}$ & $\begin{array}{l}\text { ENDF } \\
\text { MAT }\end{array}$ & MOD & $\begin{array}{l}\text { Eval. } \\
\text { date }\end{array}$ & $\begin{array}{l}\text { Resonance } \\
\text { data }\end{array}$ & $\begin{array}{c}\text { Thermal } \\
\text { MAT }\end{array}$ \\
\hline $54-X e-130$ & 54130 & 1350 & 1 & Mar 1978 & ML12 & \\
\hline $54-X e-131$ & 54131 & 1351 & 1 & Mar 1978 & ML40 & \\
\hline 54-Ze-132 & 54132 & 1352 & 2 & Mar 1978 & ML4 & \\
\hline $54-X e-133$ & 54133 & 9643 & 1 & Dec 1979 & & \\
\hline $54-X e-134$ & 54134 & 1354 & 1 & Mar 1978 & ML3 & \\
\hline 54-Xe-135 & 54135 & 1294 & 1 & Jun 1967 & & \\
\hline 54-Xe-136 & 54136 & 1356 & 1 & Mar 1978 & & \\
\hline 39-Y-89 & 39089 & 9202 & 1 & Apr 1974 & SL16 & \\
\hline 39-Y-90 & 39090 & 9204 & 1 & Dec 1979 & ML397 & \\
\hline 39-Y-91 & 39091 & 9206 & 1 & Dec 1979 & ML123 & \\
\hline $40-\mathrm{Zr}$ & 40000 & 1340 & 2 & Apr 1976 & ML94 & \\
\hline $40-Z r-90$ & 40090 & 1385 & 2 & Apr 1976 & ML79 & \\
\hline $40-Z r-91$ & 40091 & 1386 & 2 & Apr 1976 & & \\
\hline $40-\mathrm{Zr}-92$ & 40092 & 1387 & 2 & Apr 1976 & ML71 & \\
\hline $40-\mathrm{Zr}-93$ & 40093 & 9232 & 1 & Dec 1979 & & \\
\hline $40-\mathrm{Zr}-94$ & 40094 & 1388 & 2 & Apr 1976 & ML30 & \\
\hline $40-\mathrm{Zr}-95$ & 40095 & 9234 & 1 & Dec 1979 & & \\
\hline $40-\mathrm{Zr}-96$ & 40096 & 1389 & 2 & Apr 1976 & & \\
\hline
\end{tabular}




\section{APPENDIX B}

\section{UNCERTAINTY IN MEASURED ACTINIDE CONCENTRATIONS}

The determination of the experimental uncertainty for the measurements discussed here is complicated because of the underestimation of some of the final sample amounts. This underestimation can occur in two ways: there can be loss of sample material by splattering, or there may be incomplete dissolution of the sample. In assessing the validity of measured values, each sample needs to be considered carefully with a view towards determining if sample loss did, in fact, occur. Where there has been sample loss, it may be possible to estimate the extent of the loss as we have shown in reporting on the analysis. Then assuming that one can identify cases where sample loss has occurred, one must be capable of determining the uncertainty in the reported experimental values.

We will report some analysis here that seeks to deduce the experimental uncertainty on the final measured value of an actinide concentration. The analysis is based on systematics of the experimental data as reported and the subsequent analysis. The experimental uncertainty is examined by looking at the following:

1. For some of the principal actinides, two samples were exposed in the PFR. In all cases, the two samples were side by side in the fuel rod. We will examine the differences in measured values for these cases.

2. We will examine the trends in $\mathrm{E} / \mathrm{C}$ ratios of sample size and principal actinide burnup. E/C, of course, depends on the reliability of the cross sections used and may thus vary from sample to sample. However, we wish to see if there are any systematic trends in the variability as a function of the parameters related to sample size. Such systematic trends would be an indicator of measurement uncertainty.

\section{Cases Involving Two Samples of an Actinide}

For each of the nuclides ${ }^{240} \mathrm{Pu},{ }^{241} \mathrm{Am},{ }^{243} \mathrm{Am}$, and ${ }^{246} \mathrm{Cm}$, two samples were exposed in the PFR. Table B.1 shows the differences between the pairs of samples for each of the four cases. These differences are shown as absolute amounts and as percentages of the average amount. In all four cases, both of the samples were of comparable size, and for three of the cases the difference in initial sample size was negligible compared to the differences in the final sample amount. However, in each case, as well as quoting the true final measured value for the second sample, a value normalized to the initial size of the first sample is also quoted. This value is given in parentheses in column four. It is then used to calculate the values in the remaining columns of the table. In this way, the initial slight variability between members of the pairs is factored out.

In Table B.1, one notes that all samples are in the range of somewhat greater than $5 \mathrm{mg}$ to slightly above $10 \mathrm{mg}$. It would seem that for samples in that size range the experimental uncertainty could be on the order of $\pm 8 \%$ in some cases. 
Table B.1. Cases involving two samples of an actinide

\begin{tabular}{|c|c|c|c|c|c|c|c|}
\hline $\begin{array}{c}\text { Sample } \\
\text { No. }\end{array}$ & $\begin{array}{l}\text { Actinide } \\
\text { species }\end{array}$ & $\begin{array}{c}\text { Beginning } \\
\text { amount } \\
(\mathrm{mg})\end{array}$ & $\begin{array}{c}\text { Ending } \\
\text { amount } \\
(\mathrm{mg})\end{array}$ & $\begin{array}{c}\text { Average } \\
\text { end } \\
\text { amount } \\
\text { (mg) }\end{array}$ & $\begin{array}{l}\text { Difference } \\
\text { in end } \\
\text { amounts } \\
(\mathrm{mg})\end{array}$ & $\begin{array}{l}\text { Difference } \\
\text { in end } \\
\text { amounts } \\
(\%)\end{array}$ & $\begin{array}{l}\text { Difference } \\
\text { from } \\
\text { average } \\
(\%)\end{array}$ \\
\hline 21 & ${ }^{240} \mathrm{Pu}$ & 10.84 & 10.26 & 9.72 & 1.08 & 11.1 & 5.5 \\
\hline 22 & ${ }^{240} \mathrm{Pu}$ & 10.82 & $\begin{array}{l}9.16 \\
(9.18)\end{array}$ & & & & \\
\hline 14 & ${ }^{241} \mathrm{Am}$ & $9.42^{a}$ & $6.21^{a}$ & 6.25 & 0.08 & 1.3 & 0.64 \\
\hline 15 & ${ }^{241} \mathrm{Am}$ & $9.52^{a}$ & $\begin{array}{r}6.36^{a} \\
(6.29)\end{array}$ & & & & \\
\hline 12 & ${ }^{243} \mathrm{Am}$ & 9.83 & 6.79 & 6.71 & 0.17 & 2.5 & 1.3 \\
\hline 13 & ${ }^{243} \mathrm{Am}$ & 9.80 & $\begin{array}{r}6.60 \\
(6.62)\end{array}$ & & & & \\
\hline 5 & ${ }^{246} \mathrm{Cm}$ & 6.69 & 4.92 & 5.32 & 0.80 & 15.0 & 7.5 \\
\hline 6 & ${ }^{246} \mathrm{Cm}$ & 6.80 & $\begin{array}{r}5.81 \\
(5.72)\end{array}$ & & & & \\
\hline
\end{tabular}

${ }^{a}$ These are the actual values measured in the laboratory. These measurements were made some time before the start of irradiation and some time after the end of radiation. Because of the half-life of ${ }^{241} \mathrm{Am}$, they differ slightly from the beginning and end of irradiation values contained, for instance, in Table D.1.

\section{Trends in E/C Values with Measured Sample Size}

If one examines the $\mathrm{E} / \mathrm{C}$ ratios for the primary actinides as a function of various sample size parameters, one sees a consistent spread in the $\mathrm{E} / \mathrm{C}$ ratio for smaller values of the various sample size parameters. Sample size parameters showing such trends are initial sample size, percentage of sample burned, and amount of sample burned, for instance. This effect is not surprising and our interest here is in the magnitude of the effect rather than its mere existence. The trend is particularly well illustrated by a plot of $\mathrm{E} / \mathrm{C}$ versus the amount of primary actinide burned which is shown in Fig. B.1 Values for about $2 \mathrm{mg}$ and lower show considerable spread. 
$\mathrm{E} / \mathrm{C}$ ratios that differ from unity are not necessarily incorrect. Such values may be indicative of cross sections that have been poorly estimated. However, quite apart from cross-section uncertainty, there will be a spread in E/C values as one goes to lower measured values because of measurement uncertainty. Figure B.1 shows where that spread becomes significant and thus is an indicator of the magnitude of the measurement uncertainty. The values deduced for the amount of a sample that is burned are the result of subtracting the final concentration from the initial concentration, and thus they contain the uncertainties of two measurements added in quadrature.

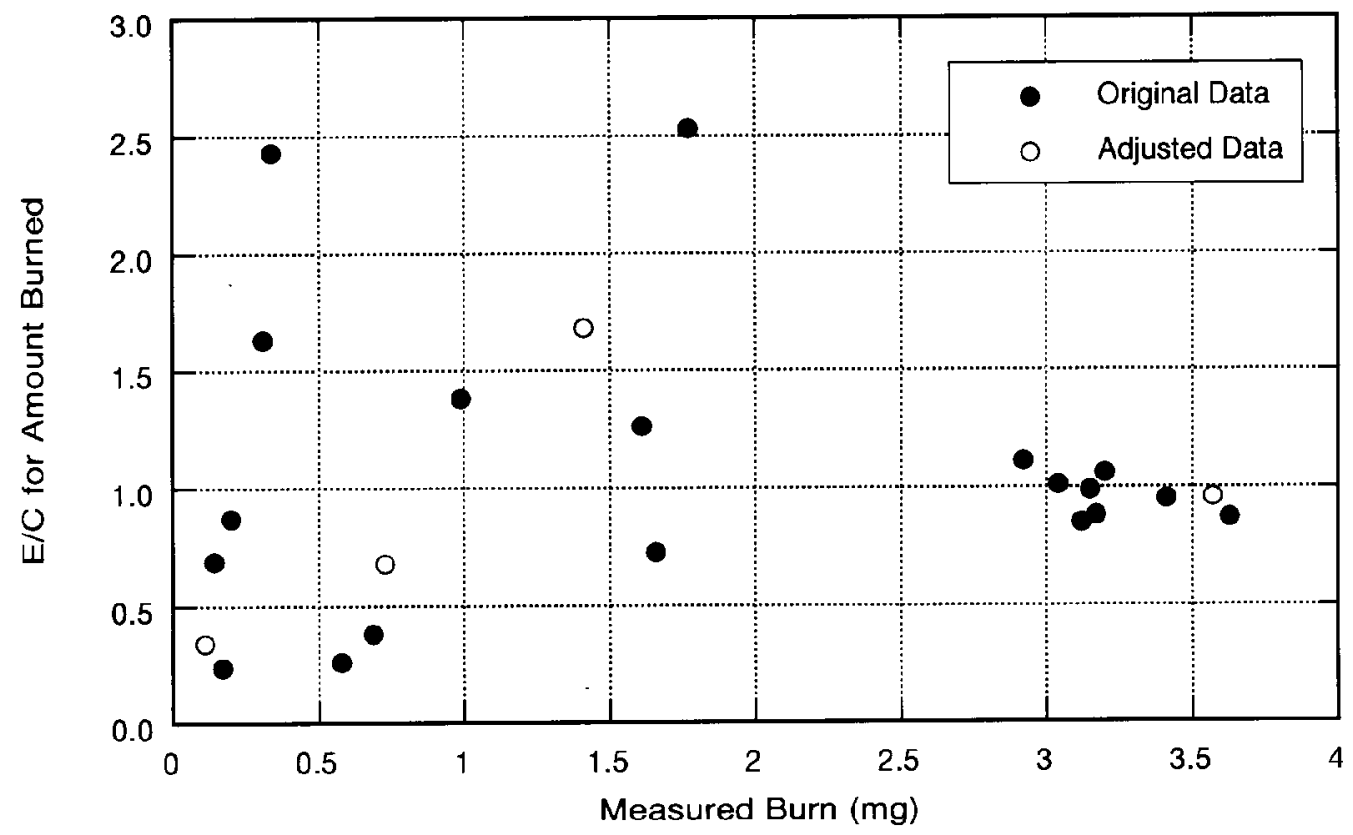

Fig. B.1. E/C ratio for the amount of a sample that is burned versus the measured amount of the burn. The plot is intended to show that as the amount of actinide burned gets smaller there is more variation in its predictability. 


\section{APPENDIX C \\ ONE-GROUP CROSS SECTIONS}

The one-group fission and capture cross sections used in the calculations are shown below in Figs. C.1 and C.2, respectively. As was mentioned earlier, separate calculations were carried out using a Dounreay purpose-written code, and these Dounreay calculations used the UK/FD5 crosssection set. The one-group cross sections from both ENDF/B-V and UK/FD5 are included in the figures for comparison purposes. There are differences between the U.S. and U.K. cross sections. These differences are greater in the case of the capture cross sections. 


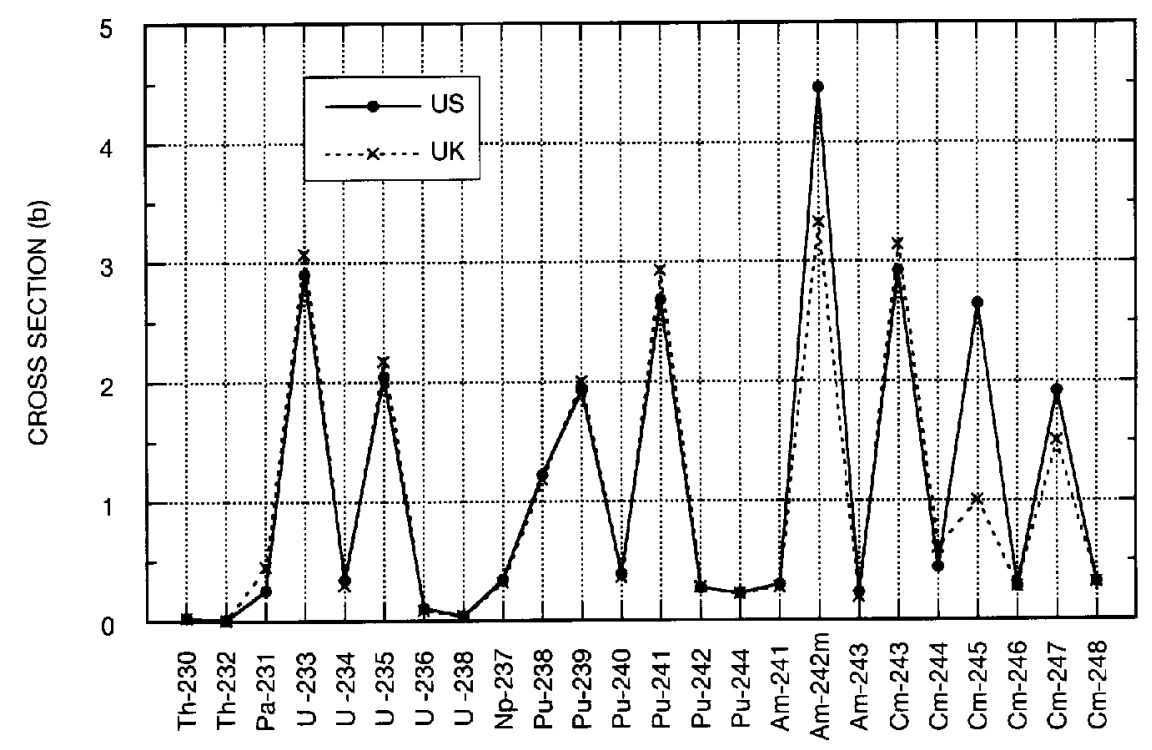

Fig. C.1. One-group actinide fission cross sections calculated for the PFR using both U.S. and U.K. cross-section data. The data points have been connected as a visual aid.

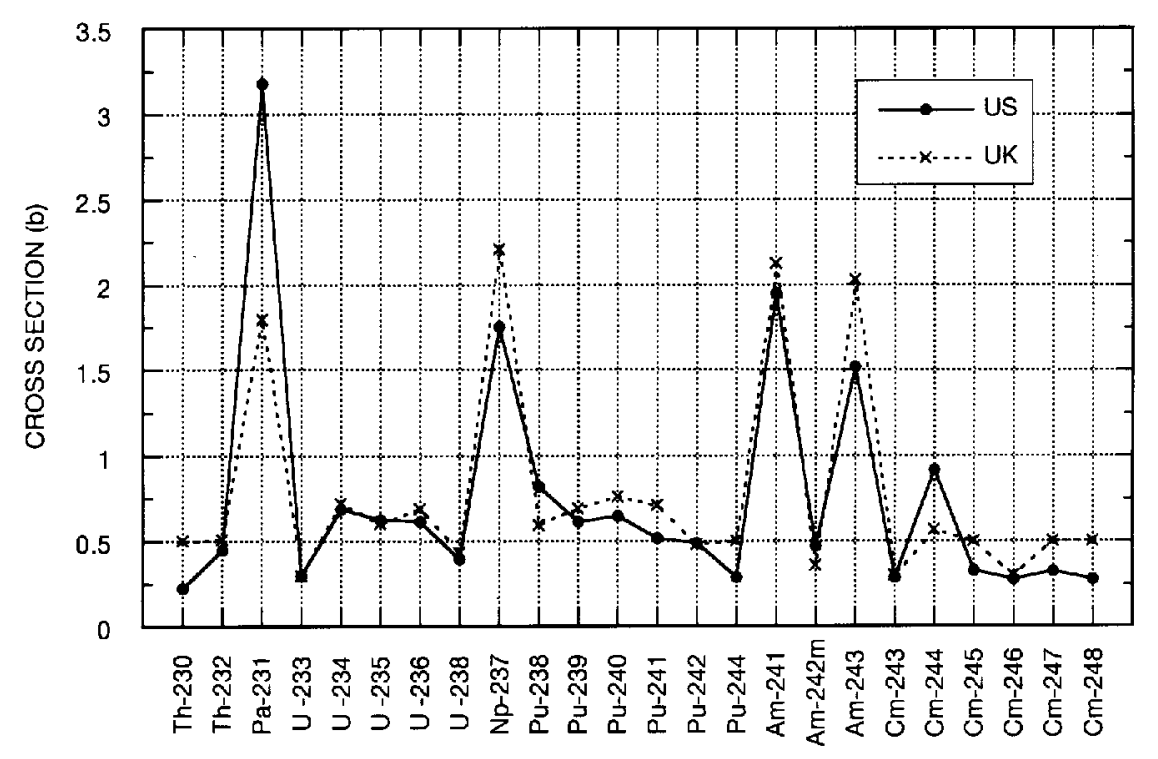

Fig. C.2. One-group actinide capture cross sections calculated for the PFR using both U.S. and U.K. cross-section data. The data points have been connected as a visual aid. 


\section{APPENDIX D}

\section{DETAILED SUMMARY OF ACTINIDE RESULTS}

The following table shows details of the amounts of primary and minor actinides for all the actinide samples that contained usable data. The nondosimeter samples are shown first, followed by the dosimeter samples. The amount of actinide is shown before and after irradiation as well as the amount predicted at the end of irradiation. These amounts are shown both in grams and in numbers of atoms. The end-of-irradiation values are for the date when irradiation actually ceased (July 8 , 1988). One should keep in mind that the measurements were made at later times, and thus when dealing with a measured value it is important to understand whether it is an actual measured value

or a value that has been "backed off" to the end-of-irradiation date. A further point about the measured values in these tables is that they have been renormalized where appropriate as outlined in Sect. 3. Where appropriate, normalization factors are noted. Final measured values for primary actinides are available unadjusted and for the time of measurement in Table 2. Table 7, on the other hand, contains the adjusted values for the primary actinides, and the values in Table 7 have also been "backed off" to the end of irradiation.

$\mathrm{E} / \mathrm{C}$ values are shown for the final amount of each actinide and in some cases for the amount of actinide that is depleted (identified as DELTA and expressed as a percent). Where an actinide is not present in a sample before irradiation, a DELTA calculation is not appropriate. Furthermore, when an actinide is originally present, but only in a negligible amount, DELTA values are not quoted since they give similar E/C values to those based simply on the final amount of the actinide. 
Table D.1. Actinide composition of sample capsules

\begin{tabular}{|c|c|c|c|c|c|c|c|c|c|c|}
\hline \multirow{2}{*}{ Nuclide } & $\begin{array}{l}\text { Begin } \\
\text { value }\end{array}$ & $\begin{array}{l}\text { Ending } \\
\text { value }\end{array}$ & $\begin{array}{c}\text { Calc. } \\
\text { value }\end{array}$ & \multirow{2}{*}{$\begin{array}{l}\text { Begin } \\
\text { (values }\end{array}$} & \multirow{2}{*}{$\begin{array}{l}\text { Ending } \\
\text { in atom nu }\end{array}$} & \multirow{2}{*}{$\begin{array}{r}\text { Calc. } \\
\text { Imbers) }\end{array}$} & \multirow[b]{2}{*}{$\mathrm{E} / \mathrm{C}$} & \multirow{2}{*}{$\begin{array}{l}\text { Delta } \\
\text { expt. (\%) }\end{array}$} & \multirow{2}{*}{$\begin{array}{l}\text { Delta } \\
\text { calc. (\%) }\end{array}$} & \multirow{2}{*}{$\begin{array}{c}\text { Delta } \\
\text { E/C }\end{array}$} \\
\hline & \multicolumn{3}{|c|}{ (values in grams) } & & & & & & & \\
\hline \multicolumn{11}{|c|}{ Th-230 Capsule (\#31) } \\
\hline Th-230 & $2.88 \mathrm{E}-3$ & $2.54 \mathrm{E}-3$ & $2.74 \mathrm{E}-3$ & $7.54 \mathrm{E} 18$ & $6.65 \mathrm{E} 18$ & 7.17E18 & 0.93 & 11.8 & 4.9 & 2.43 \\
\hline Th-232 & $3.42 \mathrm{E}-4$ & $3.19 \mathrm{E}-4$ & $3.12 \mathrm{E}-4$ & $8.88 \mathrm{E} 17$ & $8.28 \mathrm{E} 17$ & $8.10 \mathrm{E} 17$ & 1.02 & 6.7 & 8.8 & 0.77 \\
\hline \multicolumn{11}{|c|}{ Th-232 Capsule (\#25) } \\
\hline Th-232 & $1.88 \mathrm{E}-2$ & $1.81 \mathrm{E}-2$ & $1.70 \mathrm{E}-2$ & $4.88 \mathrm{E} 19$ & $4.70 \mathrm{E} 19$ & $4.41 \mathrm{E} 19$ & 1.07 & 3.7 & 9.6 & 0.38 \\
\hline U-233 & - & $1.29 \mathrm{E}-3$ & $1.15 \mathrm{E}-3$ & - & $3.33 \mathrm{E} 18$ & 2.97E18 & 1.12 & & & \\
\hline U-234 & - & $6.70 \mathrm{E}-5$ & $5.51 \mathrm{E}-5$ & - & $1.72 \mathrm{E} 17$ & $1.42 \mathrm{E} 17$ & 1.22 & & & \\
\hline \multicolumn{11}{|c|}{ Pa-231 Capsule (\#29) } \\
\hline $\mathrm{Pa}-231$ & $2.51 \mathrm{E}-3$ & $9.00 \mathrm{E}-4$ & $1.23 \mathrm{E}-3$ & $6.55 \mathrm{E} 18$ & $2.35 \mathrm{E} 18$ & $3.21 \mathrm{E} 18$ & 0.73 & 64.2 & 51.0 & 1.26 \\
\hline U-232 & - & 4.23E-4 & $8.11 \mathrm{E}-4$ & - & $1.10 \mathrm{E} 18$ & $2.11 \mathrm{E} 18$ & 0.52 & & & \\
\hline \multicolumn{11}{|c|}{ U-234 Capsule (\#27) } \\
\hline U-234 & $3.50 \mathrm{E}-3$ & $3.33 \mathrm{E}-3$ & $2.80 \mathrm{E}-3$ & $9.01 \mathrm{E} 18$ & $8.57 \mathrm{E} 18$ & $7.21 \mathrm{E} 18$ & 1.19 & 4.9 & 20.0 & 0.24 \\
\hline U-235 & $5.92 \mathrm{E}-6$ & $4.14 \mathrm{E}-4$ & $3.47 \mathrm{E}-4$ & $1.52 \mathrm{E} 16$ & $1.06 \mathrm{E} 18$ & $8.89 \mathrm{E} 17$ & 1.19 & & & \\
\hline U-236 & $1.42 \mathrm{E}-6$ & $3.24 \mathrm{E}-5$ & $2.66 \mathrm{E}-5$ & $3.62 \mathrm{E} 15$ & $8.27 \mathrm{E} 16$ & $6.79 \mathrm{E} 16$ & 1.22 & & & \\
\hline U-238 & $8.56 \mathrm{E}-7$ & $1.38 \mathrm{E}-6$ & $7.82 \mathrm{E}-7$ & $2.17 \mathrm{E} 15$ & $3.50 \mathrm{E} 15$ & $1.98 \mathrm{E} 15$ & 1.77 & -61.6 & 8.6 & -7.1 \\
\hline \multicolumn{11}{|c|}{ U-235 Capsule (\#28) } \\
\hline U-235 & $8.37 \mathrm{E}-3$ & $4.96 \mathrm{E}-3$ & $4.78 \mathrm{E}-3$ & $2.14 \mathrm{E} 19$ & $1.27 \mathrm{E} 19$ & $1.22 \mathrm{E} 19$ & 1.04 & 40.7 & 42.9 & 0.95 \\
\hline U-236 & $2.10 \mathrm{E}-6$ & $8.35 \mathrm{E}-4$ & $7.72 \mathrm{E}-4$ & $5.36 \mathrm{E} 15$ & $2.13 \mathrm{E} 18$ & $1.97 \mathrm{E} 18$ & 1.08 & & & \\
\hline U-238 & $4.50 \mathrm{E}-6$ & $3.88 \mathrm{E}-6$ & $4.20 \mathrm{E}-6$ & $1.14 \mathrm{E} 16$ & $9.82 \mathrm{E} 15$ & $1.06 \mathrm{E} 16$ & 0.92 & 13.8 & 6.7 & 2.07 \\
\hline \multicolumn{6}{|c|}{ U-236 Capsule (\#26) } & \multicolumn{5}{|c|}{$($ Normalization Factor $=1.96)$} \\
\hline $\mathrm{U}-233$ & $1.83 \mathrm{E}-5$ & $7.02 \mathrm{E}-6$ & $9.07 \mathrm{E}-6$ & 4.73E16 & $1.82 \mathrm{E} 16$ & $2.34 \mathrm{E} 16$ & 0.77 & 61.6 & 50.4 & 1.22 \\
\hline U-234 & $1.08 \mathrm{E}-5$ & $1.35 \mathrm{E}-5$ & $1.14 \mathrm{E}-5$ & $2.78 \mathrm{E} 16$ & $3.46 \mathrm{E} 16$ & 2.93E16 & 1.18 & -24.6 & -5.6 & 4.43 \\
\hline U-235 & $8.34 \mathrm{E}-4$ & $4.88 \mathrm{E}-4$ & $4.70 \mathrm{E}-4$ & $2.14 \mathrm{E} 18$ & $1.25 \mathrm{E} 18$ & $1.20 \mathrm{E} 18$ & 1.04 & 41.5 & 43.7 & 0.95 \\
\hline U-236 & $7.96 \mathrm{E}-3$ & 7.23E-3 & $6.88 \mathrm{E}-3$ & 2.03E19 & $1.84 \mathrm{E} 19$ & $1.76 \mathrm{E} 19$ & 1.05 & 9.2 & 13.6 & 0.68 \\
\hline U-238 & $1.26 \mathrm{E}-4$ & $1.57 \mathrm{E}-4$ & $1.16 \mathrm{E}-4$ & $3.19 \mathrm{E} 17$ & $3.97 \mathrm{E} 17$ & 2.94E17 & 1.35 & -24.6 & 7.9 & -3.10 \\
\hline Np-237 & $2.45 \mathrm{E}-4$ & $1.31 \mathrm{E}-3$ & $9.25 \mathrm{E}-4$ & $6.23 \mathrm{E} 17$ & $3.33 \mathrm{E} 18$ & $2.35 \mathrm{E} 18$ & 1.42 & -434.7 & -277.6 & 1.57 \\
\hline Pu-238 & - & $1.67 \mathrm{E}-4$ & $1.91 \mathrm{E}-4$ & - & $4.23 \mathrm{E} 17$ & 4.83E17 & 0.87 & & & \\
\hline Pu-239 & - & $1.56 \mathrm{E}-5$ & $2.00 \mathrm{E}-5$ & - & $3.93 \mathrm{E} 16$ & $5.04 \mathrm{E} 16$ & 0.78 & & & \\
\hline $\mathrm{Pu}-240$ & - & $8.53 \mathrm{E}-7$ & $9.91 \mathrm{E}-7$ & - & $2.14 \mathrm{E} 15$ & 2.49E15 & 0.86 & & & \\
\hline $\mathrm{Pu}-241$ & - & $2.77 \mathrm{E}-8$ & $3.57 \mathrm{E}-8$ & - & $6.93 \mathrm{E} 13$ & 8.92E13 & 0.78 & & & \\
\hline \multicolumn{6}{|c|}{ U-238 Capsule (\#11) } & \multicolumn{5}{|c|}{$($ Normalization Factor $=4.8)$} \\
\hline U-235 & 4.26E-6 & $2.57 \mathrm{E}-6$ & $2.49 \mathrm{E}-6$ & $1.09 \mathrm{E} 16$ & $6.59 \mathrm{E} 15$ & $6.38 \mathrm{E} 15$ & 1.03 & 39.7 & 41.6 & 0.95 \\
\hline U-238 & $9.81 \mathrm{E}-3$ & $8.40 \mathrm{E}-3$ & $8.97 \mathrm{E}-3$ & $2.48 \mathrm{E} 19$ & 2.13E19 & 2.27E19 & 0.94 & 14.4 & 8.6 & 1.68 \\
\hline Pu-239 & - & $5.00 \mathrm{E}-4$ & $5.74 \mathrm{E}-4$ & - & $1.26 \mathrm{E} 18$ & $1.45 \mathrm{E} 18$ & 0.87 & & & \\
\hline $\mathrm{Pu}-240$ & - & $3.40 \mathrm{E}-5$ & $3.74 \mathrm{E}-5$ & - & $8.53 \mathrm{E} 16$ & $9.38 \mathrm{E} 16$ & 0.91 & & & \\
\hline
\end{tabular}


Table D.1 (continued)

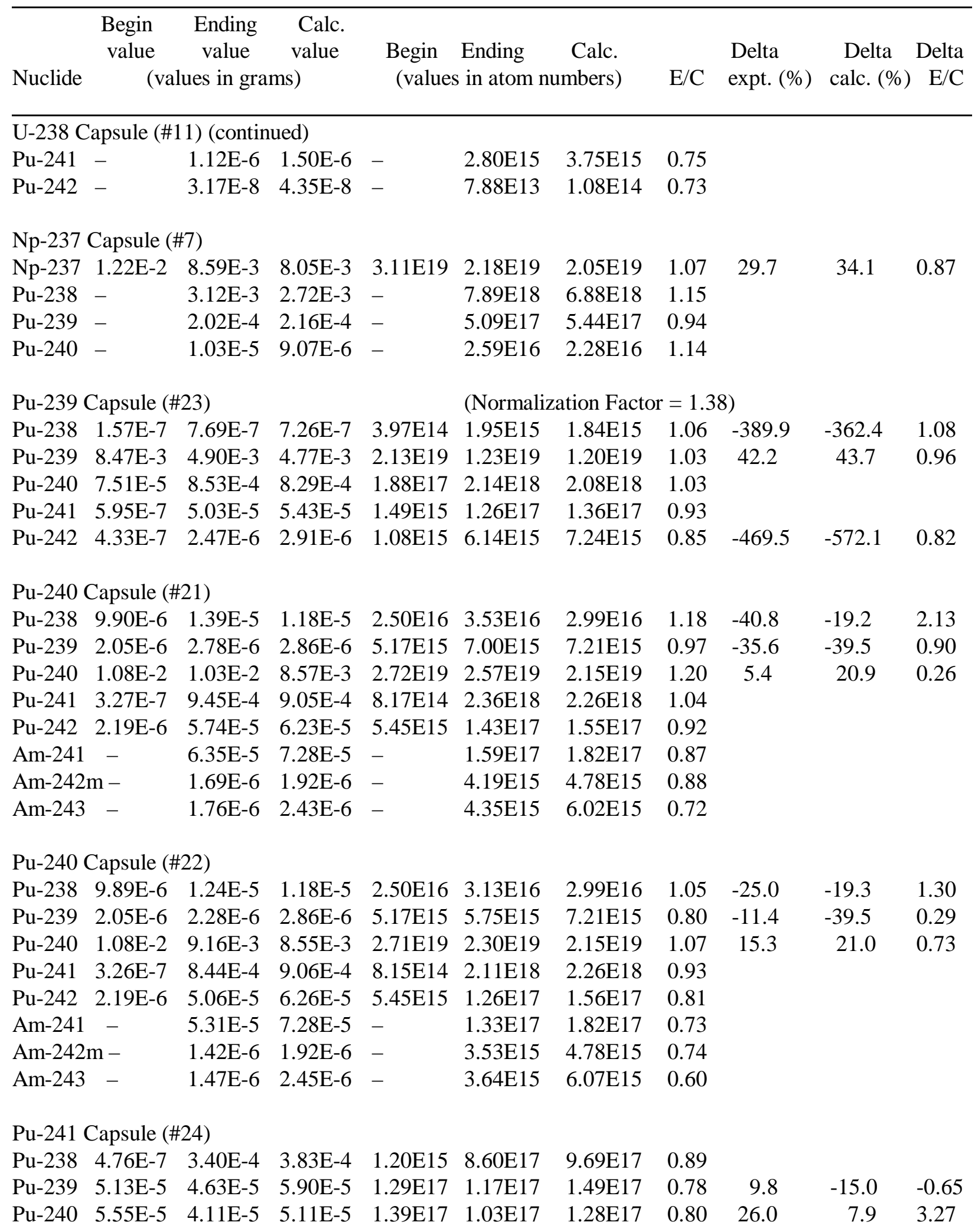


Table D.1 (continued)

\begin{tabular}{|c|c|c|c|c|c|c|c|c|c|c|}
\hline \multirow{2}{*}{ Nuclide } & $\begin{array}{l}\text { Begin } \\
\text { value }\end{array}$ & $\begin{array}{l}\text { Ending } \\
\text { value }\end{array}$ & $\begin{array}{l}\text { Calc. } \\
\text { value }\end{array}$ & & & & \multirow{2}{*}{$\mathrm{E} / \mathrm{C} \mathrm{e}$} & \multirow{2}{*}{$\begin{array}{l}\text { Delta } \\
\text { expt. (\%) }\end{array}$} & \multirow{2}{*}{$\begin{array}{l}\text { Delta } \\
\text { calc. (\%) }\end{array}$} & \multirow{2}{*}{$\begin{array}{c}\text { Delta } \\
\text { E/C }\end{array}$} \\
\hline & \multicolumn{3}{|c|}{ (values in grams) } & \multicolumn{3}{|c|}{ (values in atom numbers) } & & & & \\
\hline \multicolumn{11}{|c|}{ Pu-241 Capsule (\#24) (continued) } \\
\hline $\mathrm{Pu}-241$ & $4.21 \mathrm{E}-3$ & $1.29 \mathrm{E}-3$ & $1.57 \mathrm{E}-3$ & $1.05 \mathrm{E} 19$ & $3.22 \mathrm{E} 18$ & $3.92 \mathrm{E} 18$ & 0.82 & 69.4 & 62.7 & 1.11 \\
\hline $\mathrm{Pu}-242$ & $3.46 \mathrm{E}-5$ & 3.13E-4 & 4.09E-4 & $8.61 \mathrm{E} 16$ & $7.79 \mathrm{E} 17$ & $1.02 \mathrm{E} 18$ & 0.77 & -804.6 & -1082.1 & 0.74 \\
\hline Am-241 & $2.04 \mathrm{E}-3$ & $1.64 \mathrm{E}-3$ & $1.83 \mathrm{E}-3$ & $5.10 \mathrm{E} 18$ & $4.10 \mathrm{E} 18$ & $4.57 \mathrm{E} 18$ & 0.90 & 19.6 & 10.3 & 1.90 \\
\hline Am-2421 & $m-$ & $8.39 \mathrm{E}-5$ & $8.84 \mathrm{E}-5$ & - & $2.09 \mathrm{E} 17$ & $2.20 \mathrm{E} 17$ & 0.95 & & & \\
\hline Am-243 & - & $2.31 \mathrm{E}-5$ & $2.82 \mathrm{E}-5$ & - & 5.73E16 & $6.99 \mathrm{E} 16$ & 0.82 & & & \\
\hline \multicolumn{5}{|c|}{ Pu-242 Capsule (\#16) } & \multicolumn{6}{|c|}{$($ Normalization Factor $=2.49)$} \\
\hline $\mathrm{Pu}-238$ & $2.55 \mathrm{E}-6$ & $1.74 \mathrm{E}-6$ & $1.61 \mathrm{E}-6$ & $6.45 \mathrm{E} 15$ & $4.39 \mathrm{E} 15$ & $4.07 \mathrm{E} 15$ & 1.08 & 31.9 & 36.9 & 0.87 \\
\hline $\mathrm{Pu}-239$ & $7.92 \mathrm{E}-6$ & 4.85E-6 & 4.86E-6 & $2.00 \mathrm{E} 16$ & $1.22 \mathrm{E} 16$ & $1.22 \mathrm{E} 16$ & 1.00 & 38.8 & 38.6 & 1.00 \\
\hline $\mathrm{Pu}-240$ & $2.12 \mathrm{E}-5$ & $1.59 \mathrm{E}-5$ & $1.85 \mathrm{E}-5$ & 5.32E16 & 3.99E16 & 4.64E16 & 0.86 & 25.0 & 12.7 & 1.96 \\
\hline $\mathrm{Pu}-242$ & $2.05 \mathrm{E}-3$ & $1.94 \mathrm{E}-3$ & $1.73 \mathrm{E}-3$ & $5.10 \mathrm{E} 18$ & $4.83 \mathrm{E} 18$ & $4.30 \mathrm{E} 18$ & 1.12 & 5.4 & 15.6 & 0.34 \\
\hline $\mathrm{Pu}-244$ & $9.01 \mathrm{E}-6$ & $6.97 \mathrm{E}-6$ & $8.06 \mathrm{E}-6$ & $2.22 \mathrm{E} 16$ & $1.72 \mathrm{E} 16$ & $1.99 \mathrm{E} 16$ & 0.86 & 22.6 & 10.5 & 2.15 \\
\hline Am-241 & $7.8 \mathrm{E}-10$ & $3.42 \mathrm{E}-7$ & 4.37E-7 & $1.95 \mathrm{E} 12$ & $8.55 \mathrm{E} 14$ & $1.09 \mathrm{E} 15$ & 0.78 & & & \\
\hline Am-243 & & $5.95 \mathrm{E}-5$ & $1.64 \mathrm{E}-4$ & - & $1.47 \mathrm{E} 17$ & $4.06 \mathrm{E} 17$ & 0.36 & & & \\
\hline \multicolumn{11}{|c|}{ Pu-244 Capsule (\#20) } \\
\hline $\mathrm{Pu}-240$ & $6.63 \mathrm{E}-5$ & $5.54 \mathrm{E}-5$ & $5.28 \mathrm{E}-5$ & $1.66 \mathrm{E} 17$ & $1.39 \mathrm{E} 17$ & $1.32 \mathrm{E} 17$ & 1.05 & 16.4 & 20.4 & 0.81 \\
\hline Pu-241 & $1.24 \mathrm{E}-5$ & $1.00 \mathrm{E}-5$ & $1.01 \mathrm{E}-5$ & $3.10 \mathrm{E} 16$ & $2.50 \mathrm{E} 16$ & $2.52 \mathrm{E} 16$ & 0.99 & 19.4 & 18.6 & 1.04 \\
\hline $\mathrm{Pu}-242$ & $2.16 \mathrm{E}-4$ & $1.90 \mathrm{E}-4$ & $1.84 \mathrm{E}-4$ & $5.38 \mathrm{E} 17$ & 4.73E17 & $4.58 \mathrm{E} 17$ & 1.03 & 12.0 & 14.8 & 0.81 \\
\hline $\mathrm{Pu}-244$ & $2.11 \mathrm{E}-3$ & $1.91 \mathrm{E}-3$ & $1.88 \mathrm{E}-3$ & $5.21 \mathrm{E} 18$ & $4.71 \mathrm{E} 18$ & $4.64 \mathrm{E} 18$ & 1.02 & 9.5 & 10.9 & 0.87 \\
\hline $\mathrm{Cm}-244$ & - & $4.02 \mathrm{E}-6$ & $2.91 \mathrm{E}-6$ & - & $9.92 \mathrm{E} 15$ & $7.18 \mathrm{E} 15$ & 1.38 & & & \\
\hline $\mathrm{Cm}-245$ & & $2.50 \mathrm{E}-5$ & $8.82 \mathrm{E}-5$ & - & $6.14 \mathrm{E} 16$ & 2.17E17 & 0.28 & & & \\
\hline $\mathrm{Cm}-246$ & & $1.22 \mathrm{E}-6$ & $3.50 \mathrm{E}-6$ & - & 2.99E15 & $8.57 \mathrm{E} 15$ & 0.35 & & & \\
\hline $\mathrm{Cm}-247$ & & $3.90 \mathrm{E}-8$ & $6.49 \mathrm{E}-8$ & - & $9.51 \mathrm{E} 13$ & $1.58 \mathrm{E} 14$ & 0.60 & & & \\
\hline \multicolumn{11}{|c|}{ Am-241 Capsule (\#14) } \\
\hline $\mathrm{Pu}-238$ & - & $1.33 \mathrm{E}-3$ & $1.30 \mathrm{E}-3$ & - & $3.36 \mathrm{E} 18$ & $3.29 \mathrm{E} 18$ & 1.02 & & & \\
\hline $\mathrm{Pu}-239$ & $4.50 \mathrm{E}-11$ & $9.99 \mathrm{E}-5$ & $1.02 \mathrm{E}-4$ & $1.13 \mathrm{E} 11$ & $2.52 \mathrm{E} 17$ & $2.57 \mathrm{E} 17$ & 0.98 & & & \\
\hline $\mathrm{Pu}-240$ & $1.17 \mathrm{E}-6$ & $9.09 \mathrm{E}-6$ & $6.93 \mathrm{E}-6$ & $2.94 \mathrm{E} 15$ & $2.28 \mathrm{E} 16$ & $1.74 \mathrm{E} 16$ & 1.31 & -676.9 & -492.3 & 1.38 \\
\hline $\mathrm{Pu}-242$ & $8.10 \mathrm{E}-11$ & 4.46E-4 & 4.04E-4 & 2.01E11 & $1.11 \mathrm{E} 18$ & $1.01 \mathrm{E} 18$ & 1.10 & & & \\
\hline Am-241 & $9.40 \mathrm{E}-3$ & $6.23 \mathrm{E}-3$ & $5.78 \mathrm{E}-3$ & $2.35 \mathrm{E} 19$ & $1.56 \mathrm{E} 19$ & $1.44 \mathrm{E} 19$ & 1.08 & 33.7 & 38.5 & 0.88 \\
\hline Am-2421 & $\mathrm{m}-$ & $3.39 \mathrm{E}-4$ & $2.92 \mathrm{E}-4$ & - & $8.44 \mathrm{E} 17$ & 7.27E17 & 1.16 & & & \\
\hline Am-243 & $3.80 \mathrm{E}-7$ & $4.25 \mathrm{E}-5$ & $3.69 \mathrm{E}-5$ & $9.42 \mathrm{E} 14$ & $1.05 \mathrm{E} 17$ & $9.14 \mathrm{E} 16$ & 1.15 & & & \\
\hline $\mathrm{Cm}-242$ & - & $6.53 \mathrm{E}-4$ & $4.48 \mathrm{E}-4$ & - & $1.62 \mathrm{E} 18$ & $1.11 \mathrm{E} 18$ & 1.46 & & & \\
\hline \multicolumn{11}{|c|}{ Am-241 Capsule (\#15) } \\
\hline $\mathrm{Pu}-238$ & - & $1.32 \mathrm{E}-3$ & $1.32 \mathrm{E}-3$ & - & $3.33 \mathrm{E} 18$ & $3.33 \mathrm{E} 18$ & 1.00 & & & \\
\hline $\mathrm{Pu}-239$ & $4.50 \mathrm{E}-11$ & $1.01 \mathrm{E}-4$ & $1.04 \mathrm{E}-4$ & $1.14 \mathrm{E} 11$ & $2.54 \mathrm{E} 17$ & $2.62 \mathrm{E} 17$ & 0.97 & & & \\
\hline $\mathrm{Pu}-240$ & $1.19 \mathrm{E}-6$ & $8.08 \mathrm{E}-6$ & $7.11 \mathrm{E}-6$ & $2.99 \mathrm{E} 15$ & 2.03E16 & $1.78 \mathrm{E} 16$ & 1.14 & -579.0 & -497.5 & 1.16 \\
\hline $\mathrm{Pu}-242$ & $1.57 \mathrm{E}-8$ & 4.42E-4 & $4.11 \mathrm{E}-4$ & $3.91 \mathrm{E} 13$ & $1.10 \mathrm{E} 18$ & $1.02 \mathrm{E} 18$ & 1.08 & & & \\
\hline Am-241 & $9.50 \mathrm{E}-3$ & $6.38 \mathrm{E}-3$ & $5.82 \mathrm{E}-3$ & $2.37 \mathrm{E} 19$ & $1.59 \mathrm{E} 19$ & $1.45 \mathrm{E} 19$ & 1.10 & 32.8 & 38.7 & 0.85 \\
\hline Am-2421 & $m-$ & $3.51 \mathrm{E}-4$ & $2.96 \mathrm{E}-4$ & - & 8.73E17 & 7.37E17 & 1.19 & & & \\
\hline
\end{tabular}


Table D.1 (continued)

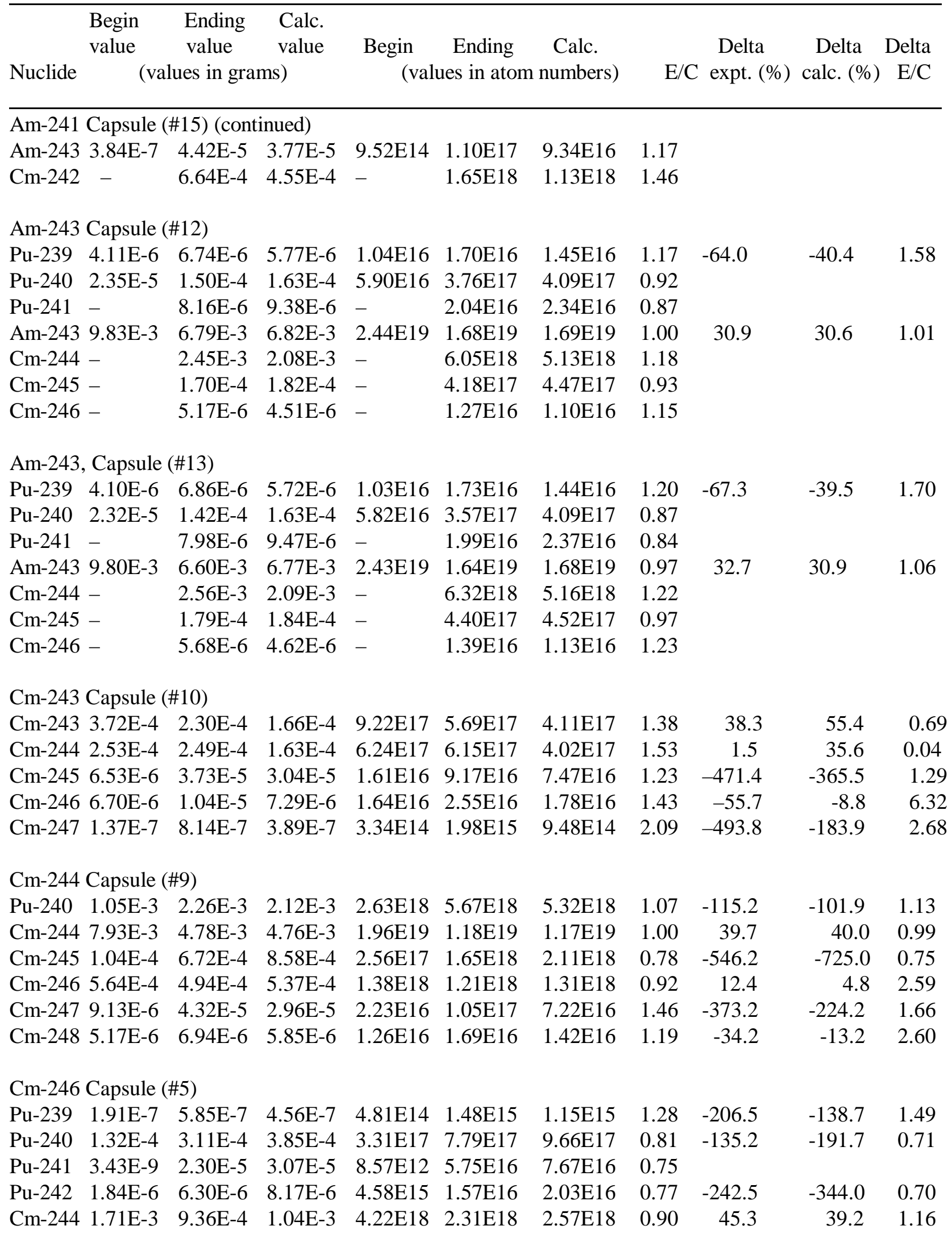


Table D.1. (continued)

\begin{tabular}{|c|c|c|c|c|c|c|c|c|c|c|}
\hline Nuclide & $\begin{array}{l}\text { Begin } \\
\text { value } \\
\quad \text { (val }\end{array}$ & $\begin{array}{l}\text { Ending } \\
\text { value } \\
\text { ues in grar }\end{array}$ & $\begin{array}{l}\text { Calc. } \\
\text { value } \\
\text { ns) }\end{array}$ & $\begin{array}{l}\text { Begin } \\
\text { (value }\end{array}$ & $\begin{array}{l}\text { Ending } \\
\text { s in atom }\end{array}$ & $\begin{array}{l}\text { Calc. } \\
\text { umbers) }\end{array}$ & $\mathrm{E} / \mathrm{C}$ & $\begin{array}{l}\text { Delta } \\
\text { expt. (\%) }\end{array}$ & $\begin{array}{c}\text { Delta } \\
\text { calc. (\%) }\end{array}$ & $\begin{array}{c}\text { Delta } \\
\text { E/C }\end{array}$ \\
\hline \multicolumn{11}{|c|}{ Cm-246 Capsule (\#5) (continued) } \\
\hline $\mathrm{Cm}-245$ & $2.34 \mathrm{E}-5$ & $1.31 \mathrm{E}-4$ & $1.83 \mathrm{E}-4$ & $5.75 \mathrm{E} 16$ & $3.23 \mathrm{E} 17$ & $4.50 \mathrm{E} 17$ & 0.72 & -461.5 & -682.1 & 0.68 \\
\hline $\mathrm{Cm}-246$ & $6.69 \mathrm{E}-3$ & $4.92 \mathrm{E}-3$ & $5.99 \mathrm{E}-3$ & $1.64 \mathrm{E} 19$ & $1.20 \mathrm{E} 19$ & $1.47 \mathrm{E} 19$ & 0.82 & 26.5 & 10.5 & 2.53 \\
\hline $\mathrm{Cm}-247$ & $1.86 \mathrm{E}-4$ & $4.70 \mathrm{E}-4$ & $3.86 \mathrm{E}-4$ & 4.53E17 & $1.15 \mathrm{E} 18$ & $9.41 \mathrm{E} 17$ & 1.22 & -152.9 & -107.5 & 1.42 \\
\hline $\mathrm{Cm}-248$ & $1.31 \mathrm{E}-3$ & $1.02 \mathrm{E}-3$ & $1.18 \mathrm{E}-3$ & $3.18 \mathrm{E} 18$ & $2.49 \mathrm{E} 18$ & 2.87E18 & 0.87 & 21.8 & 9.9 & 2.20 \\
\hline \multicolumn{11}{|c|}{ Cm-246 Capsule (\#6) } \\
\hline $\mathrm{Pu}-239$ & $1.94 \mathrm{E}-7$ & 3.92E-7 & $4.66 \mathrm{E}-7$ & $4.89 \mathrm{E} 14$ & $9.87 \mathrm{E} 14$ & $1.17 \mathrm{E} 15$ & 0.84 & -102.0 & -140.2 & 0.73 \\
\hline $\mathrm{Pu}-240$ & $1.35 \mathrm{E}-4$ & $3.82 \mathrm{E}-4$ & $3.91 \mathrm{E}-4$ & 3.39E17 & $9.57 \mathrm{E} 17$ & $9.81 \mathrm{E} 17$ & 0.98 & -182.7 & -189.6 & 0.96 \\
\hline $\mathrm{Pu}-241$ & $3.48 \mathrm{E}-9$ & $2.84 \mathrm{E}-5$ & $3.15 \mathrm{E}-5$ & $8.70 \mathrm{E} 12$ & $7.10 \mathrm{E} 16$ & 7.87E16 & 0.90 & & & \\
\hline $\mathrm{Pu}-242$ & $1.87 \mathrm{E}-6$ & 7.74E-6 & $8.33 \mathrm{E}-6$ & 4.65E15 & $1.93 \mathrm{E} 16$ & $2.07 \mathrm{E} 16$ & 0.93 & -313.9 & -345.5 & 0.91 \\
\hline $\mathrm{Cm}-244$ & $1.74 \mathrm{E}-3$ & $1.11 \mathrm{E}-3$ & $1.05 \mathrm{E}-3$ & $4.29 \mathrm{E} 18$ & $2.74 \mathrm{E} 18$ & $2.59 \mathrm{E} 18$ & 1.06 & 36.3 & 39.7 & 0.91 \\
\hline $\mathrm{Cm}-245$ & $2.38 \mathrm{E}-5$ & $1.55 \mathrm{E}-4$ & $1.87 \mathrm{E}-4$ & $5.85 \mathrm{E} 16$ & $3.81 \mathrm{E} 17$ & $4.60 \mathrm{E} 17$ & 0.83 & -551.3 & -685.7 & 0.80 \\
\hline $\mathrm{Cm}-246$ & $6.80 \mathrm{E}-3$ & $5.81 \mathrm{E}-3$ & $6.08 \mathrm{E}-3$ & $1.66 \mathrm{E} 19$ & $1.42 \mathrm{E} 19$ & $1.49 \mathrm{E} 19$ & 0.96 & 14.6 & 10.6 & 1.38 \\
\hline $\mathrm{Cm}-247$ & $1.89 \mathrm{E}-4$ & $5.58 \mathrm{E}-4$ & $3.94 \mathrm{E}-4$ & 4.61E17 & $1.36 \mathrm{E} 18$ & $9.61 \mathrm{E} 17$ & 1.42 & -195.2 & -108.5 & 1.80 \\
\hline $\mathrm{Cm}-248$ & $1.33 \mathrm{E}-3$ & $1.20 \mathrm{E}-3$ & $1.20 \mathrm{E}-3$ & 3.23E18 & $2.91 \mathrm{E} 18$ & 2.91E18 & 1.00 & 9.8 & 9.8 & 1.00 \\
\hline \multicolumn{11}{|c|}{ Cm-248 Capsule (\#4) } \\
\hline $\mathrm{Cm}-244$ & $5.77 \mathrm{E}-5$ & $3.50 \mathrm{E}-5$ & $3.51 \mathrm{E}-5$ & $1.42 \mathrm{E} 17$ & $8.64 \mathrm{E} 16$ & $8.66 \mathrm{E} 16$ & 1.00 & 39.3 & 39.2 & 1.00 \\
\hline $\mathrm{Cm}-245$ & $1.93 \mathrm{E}-6$ & $5.38 \mathrm{E}-6$ & $6.86 \mathrm{E}-6$ & $4.74 \mathrm{E} 15$ & $1.32 \mathrm{E} 16$ & $1.69 \mathrm{E} 16$ & 0.78 & -178.8 & -255.4 & 0.70 \\
\hline $\mathrm{Cm}-246$ & $8.56 \mathrm{E}-5$ & $6.95 \mathrm{E}-5$ & $7.72 \mathrm{E}-5$ & $2.10 \mathrm{E} 17$ & $1.70 \mathrm{E} 17$ & $1.89 \mathrm{E} 17$ & 0.90 & 18.8 & 9.8 & 1.92 \\
\hline $\mathrm{Cm}-247$ & $1.64 \mathrm{E}-6$ & $6.39 \mathrm{E}-6$ & $4.68 \mathrm{E}-6$ & 4.00E15 & $1.56 \mathrm{E} 16$ & $1.14 \mathrm{E} 16$ & 1.37 & -289.6 & -185.4 & 1.56 \\
\hline $\mathrm{Cm}-248$ & $1.76 \mathrm{E}-3$ & $1.45 \mathrm{E}-3$ & $1.57 \mathrm{E}-3$ & $4.27 \mathrm{E} 18$ & $3.52 \mathrm{E} 18$ & $3.81 \mathrm{E} 18$ & 0.92 & 17.6 & 10.8 & 1.63 \\
\hline Bk-249 & - & $1.89 \mathrm{E}-5$ & $3.19 \mathrm{E}-5$ & - & $4.57 \mathrm{E} 16$ & $7.71 \mathrm{E} 16$ & 0.59 & & & \\
\hline \multicolumn{5}{|c|}{ Capsule \#1 (U-235/U-238) } & \multicolumn{6}{|c|}{$($ Normalization Factor $=1.85)$} \\
\hline U-235 & $1.18 \mathrm{E}-3$ & 7.40E-4 & $7.21 \mathrm{E}-4$ & $3.02 \mathrm{E} 18$ & $1.90 \mathrm{E} 18$ & $1.85 \mathrm{E} 18$ & 1.03 & 37.3 & 38.9 & 0.96 \\
\hline U-236 & - & $1.06 \mathrm{E}-4$ & $9.94 \mathrm{E}-5$ & - & $2.70 \mathrm{E} 17$ & $2.54 \mathrm{E} 17$ & 1.07 & & & \\
\hline U-238 & $1.18 \mathrm{E}-3$ & $1.11 \mathrm{E}-3$ & $1.09 \mathrm{E}-3$ & $2.99 \mathrm{E} 18$ & $2.81 \mathrm{E} 18$ & $2.76 \mathrm{E} 18$ & 1.02 & 5.9 & 7.6 & 0.78 \\
\hline $\mathrm{Pu}-238$ & - & $6.55 \mathrm{E}-7$ & $5.93 \mathrm{E}-7$ & - & $1.66 \mathrm{E} 15$ & $1.50 \mathrm{E} 15$ & 1.10 & & & \\
\hline Pu-239 & - & $5.68 \mathrm{E}-5$ & $6.35 \mathrm{E}-5$ & - & $1.43 \mathrm{E} 17$ & $1.60 \mathrm{E} 17$ & 0.89 & & & \\
\hline $\mathrm{Pu}-240$ & - & $3.44 \mathrm{E}-6$ & $3.66 \mathrm{E}-6$ & - & $8.63 \mathrm{E} 15$ & $9.18 \mathrm{E} 15$ & 0.94 & & & \\
\hline \multicolumn{11}{|c|}{ Capsule \#2 (Np-237/Pu-239) } \\
\hline Np-237 & $1.04 \mathrm{E}-3$ & $6.20 \mathrm{E}-4$ & 7.03E-4 & $2.64 \mathrm{E} 18$ & $1.58 \mathrm{E} 18$ & $1.79 \mathrm{E} 18$ & 0.88 & 40.4 & 32.4 & 1.25 \\
\hline $\mathrm{Pu}-238$ & $2.22 \mathrm{E}-9$ & $2.47 \mathrm{E}-4$ & $2.24 \mathrm{E}-4$ & $5.62 \mathrm{E} 12$ & $6.25 \mathrm{E} 17$ & $5.67 \mathrm{E} 17$ & 1.10 & & & \\
\hline Pu-239 & $1.20 \mathrm{E}-3$ & 7.71E-4 & $7.60 \mathrm{E}-4$ & $3.02 \mathrm{E} 18$ & $1.94 \mathrm{E} 18$ & $1.91 \mathrm{E} 18$ & 1.01 & 35.8 & 36.7 & 0.98 \\
\hline $\mathrm{Pu}-240$ & $1.07 \mathrm{E}-5$ & $1.12 \mathrm{E}-4$ & $1.07 \mathrm{E}-4$ & $2.68 \mathrm{E} 16$ & $2.81 \mathrm{E} 17$ & $2.68 \mathrm{E} 17$ & 1.05 & & & \\
\hline $\mathrm{Pu}-241$ & $8.42 \mathrm{E}-8$ & $5.25 \mathrm{E}-6$ & $5.99 \mathrm{E}-6$ & $2.10 \mathrm{E} 14$ & $1.31 \mathrm{E} 16$ & $1.50 \mathrm{E} 16$ & 0.88 & & & \\
\hline $\mathrm{Pu}-242$ & $6.13 \mathrm{E}-8$ & 2.93E-7 & $2.88 \mathrm{E}-7$ & $1.53 \mathrm{E} 14$ & $7.29 \mathrm{E} 14$ & 7.17E14 & 1.02 & & & \\
\hline
\end{tabular}


Table D.1. (continued)

\begin{tabular}{|c|c|c|c|c|c|c|c|c|c|c|}
\hline Nuclide & $\begin{array}{l}\text { Begin } \\
\text { value } \\
\quad \text { (val }\end{array}$ & $\begin{array}{l}\text { Ending } \\
\text { value } \\
\text { lues in grar }\end{array}$ & $\begin{array}{l}\text { Calc. } \\
\text { value } \\
\text { ms) }\end{array}$ & $\begin{array}{l}\text { Begin } \\
\text { (values }\end{array}$ & $\begin{array}{l}\text { Ending } \\
\text { in atom nt }\end{array}$ & $\begin{array}{l}\text { Calc. } \\
\text { imbers) }\end{array}$ & $\mathrm{E} / \mathrm{C}$ & $\begin{array}{c}\text { Delta } \\
\text { expt. (\%) }\end{array}$ & $\begin{array}{l}\text { Delta } \\
\text { calc. (\%) }\end{array}$ & $\begin{array}{c}\text { Delta } \\
\text { E/C }\end{array}$ \\
\hline \multicolumn{5}{|c|}{ Capsule \#17 (U-235/U-238) } & \multicolumn{6}{|c|}{$($ Normalization Factor $=1.90)$} \\
\hline U-235 & $1.11 \mathrm{E}-3$ & $6.46 \mathrm{E}-4$ & $6.21 \mathrm{E}-4$ & $2.84 \mathrm{E} 18$ & $1.66 \mathrm{E} 18$ & $1.59 \mathrm{E} 18$ & 1.04 & 41.8 & 44.1 & 0.95 \\
\hline U-236 & - & $1.10 \mathrm{E}-4$ & $1.04 \mathrm{E}-4$ & - & $2.81 \mathrm{E} 17$ & $2.65 \mathrm{E} 17$ & 1.06 & & & \\
\hline $\mathrm{U}-238$ & $9.80 \mathrm{E}-4$ & $9.50 \mathrm{E}-4$ & $8.92 \mathrm{E}-4$ & $2.48 \mathrm{E} 18$ & $2.40 \mathrm{E} 18$ & $2.26 \mathrm{E} 18$ & 1.07 & 3.1 & 9.0 & 0.34 \\
\hline $\mathrm{Pu}-238$ & - & $9.34 \mathrm{E}-7$ & $8.40 \mathrm{E}-7$ & - & $2.36 \mathrm{E} 15$ & $2.13 \mathrm{E} 15$ & 1.11 & & & \\
\hline $\mathrm{Pu}-239$ & - & $5.37 \mathrm{E}-5$ & $5.93 \mathrm{E}-5$ & - & $1.35 \mathrm{E} 17$ & $1.49 \mathrm{E} 17$ & 0.91 & & & \\
\hline $\mathrm{Pu}-240$ & - & $3.80 \mathrm{E}-6$ & $4.04 \mathrm{E}-6$ & - & $9.53 \mathrm{E} 15$ & $1.01 \mathrm{E} 16$ & 0.94 & & & \\
\hline \multicolumn{11}{|c|}{ Capsule \#18 (Np-237/Pu-239) } \\
\hline Np-237 & $1.12 \mathrm{E}-3$ & $6.20 \mathrm{E}-4$ & 7.09E-4 & $2.85 \mathrm{E} 18$ & $1.58 \mathrm{E} 18$ & $1.80 \mathrm{E} 18$ & 0.87 & 44.6 & 36.7 & 1.22 \\
\hline $\mathrm{Pu}-238$ & $2.07 \mathrm{E}-9$ & $2.81 \mathrm{E}-4$ & $2.63 \mathrm{E}-4$ & $5.24 \mathrm{E} 12$ & 7.11E17 & $6.65 \mathrm{E} 17$ & 1.07 & & & \\
\hline $\mathrm{Pu}-239$ & $1.12 \mathrm{E}-3$ & $6.80 \mathrm{E}-4$ & $6.63 \mathrm{E}-4$ & $2.82 \mathrm{E} 18$ & $1.71 \mathrm{E} 18$ & $1.67 \mathrm{E} 18$ & 1.03 & 39.3 & 40.8 & 0.96 \\
\hline $\mathrm{Pu}-240$ & $9.99 \mathrm{E}-6$ & $1.14 \mathrm{E}-4$ & $1.09 \mathrm{E}-4$ & $2.51 \mathrm{E} 16$ & $2.86 \mathrm{E} 17$ & 2.73E17 & 1.05 & & & \\
\hline $\mathrm{Pu}-241$ & $7.84 \mathrm{E}-8$ & $6.84 \mathrm{E}-6$ & $6.96 \mathrm{E}-6$ & $1.96 \mathrm{E} 14$ & $1.71 \mathrm{E} 16$ & $1.74 \mathrm{E} 16$ & 0.98 & & & \\
\hline $\mathrm{Pu}-242$ & $5.72 \mathrm{E}-8$ & $3.71 \mathrm{E}-7$ & $3.65 \mathrm{E}-7$ & $1.42 \mathrm{E} 14$ & $9.23 \mathrm{E} 14$ & $9.08 \mathrm{E} 14$ & 1.02 & & & \\
\hline \multicolumn{11}{|c|}{ Capsule \#34 (Np-237/Pu-239) } \\
\hline Np-237 & $1.18 \mathrm{E}-3$ & $5.90 \mathrm{E}-4$ & $7.82 \mathrm{E}-4$ & $3.00 \mathrm{E} 18$ & $1.50 \mathrm{E} 18$ & $1.99 \mathrm{E} 18$ & 0.75 & 50.0 & 33.7 & 1.48 \\
\hline $\mathrm{Pu}-238$ & $2.18 \mathrm{E}-9$ & $2.76 \mathrm{E}-4$ & $2.61 \mathrm{E}-4$ & $5.52 \mathrm{E} 12$ & $6.98 \mathrm{E} 17$ & $6.60 \mathrm{E} 17$ & 1.06 & & & \\
\hline $\mathrm{Pu}-239$ & $1.18 \mathrm{E}-3$ & $6.90 \mathrm{E}-4$ & 7.34E-4 & $2.97 \mathrm{E} 18$ & $1.74 \mathrm{E} 18$ & $1.85 \mathrm{E} 18$ & 0.94 & 41.5 & 37.8 & 1.10 \\
\hline $\mathrm{Pu}-240$ & $1.05 \mathrm{E}-5$ & $1.13 \mathrm{E}-4$ & $1.08 \mathrm{E}-4$ & 2.63E16 & 2.84E17 & $2.71 \mathrm{E} 17$ & 1.05 & & & \\
\hline $\mathrm{Pu}-241$ & $8.28 \mathrm{E}-8$ & $6.77 \mathrm{E}-6$ & $6.31 \mathrm{E}-6$ & 2.07E14 & $1.69 \mathrm{E} 16$ & $1.58 \mathrm{E} 16$ & 1.07 & & & \\
\hline $\mathrm{Pu}-242$ & $6.03 \mathrm{E}-8$ & $3.50 \mathrm{E}-7$ & $3.10 \mathrm{E}-7$ & $1.50 \mathrm{E} 14$ & 8.71E14 & $7.71 \mathrm{E} 14$ & 1.13 & & & \\
\hline
\end{tabular}




\section{APPENDIX E}

\section{DETAILED SUMMARY OF FISSION-PRODUCT MEASURED RESULTS}

The measured amount of each of the nine fission products is shown in Table E.1 for all nondosimeter samples that yielded useable data. The number of atoms in the analyzed aliquot and the corresponding amount of grams in the sample are shown. The size of the aliquot, as a percentage of the sample, is also shown in the third column. These data refer to the end-of-irradiation date. They reflect the actual laboratory measurements and therefore do not account for corrections because of sample loss. 


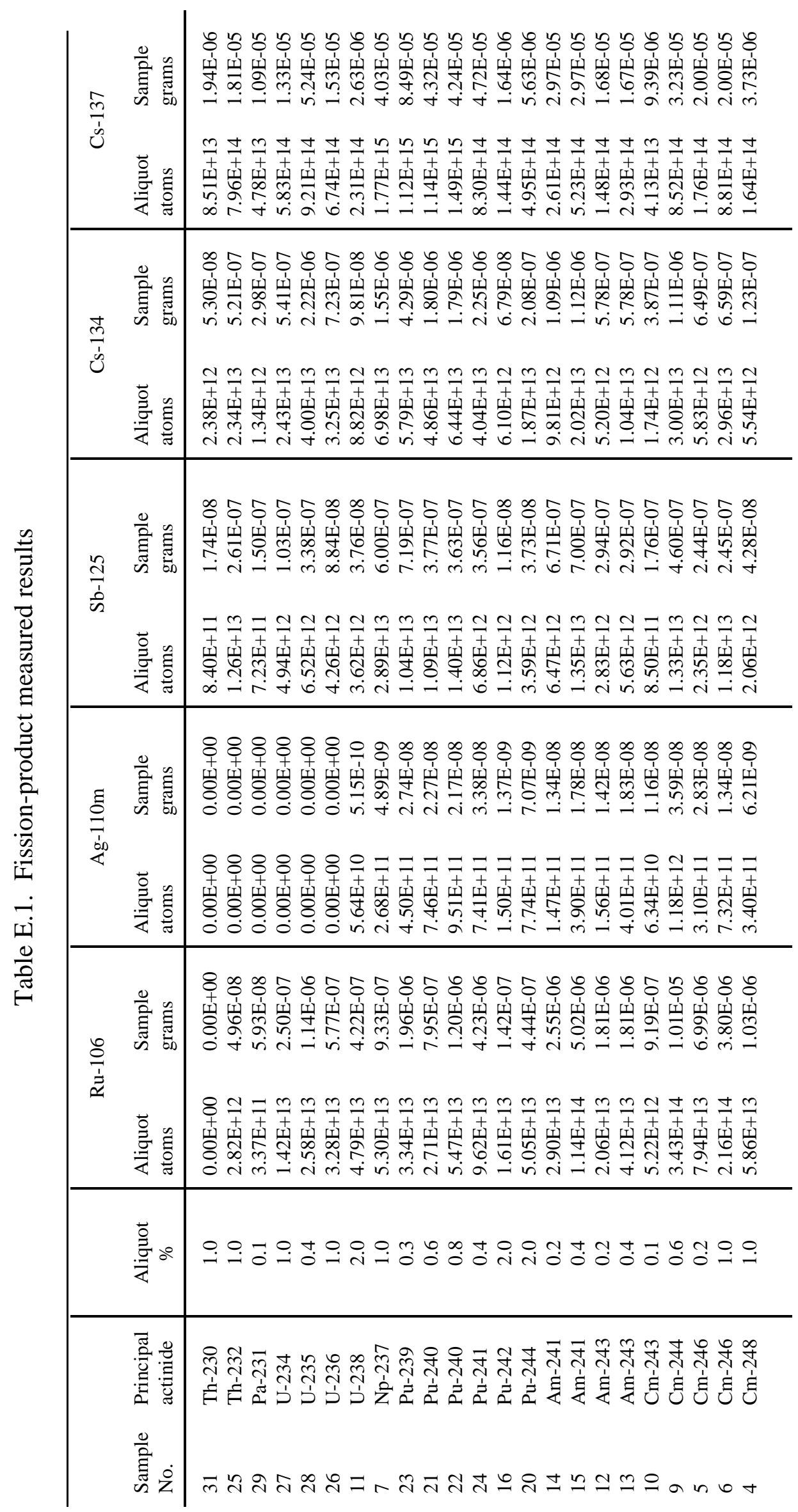




\begin{tabular}{|c|c|c|}
\hline $\begin{array}{l}n \\
\frac{n}{1} \\
\frac{1}{1}\end{array}$ & 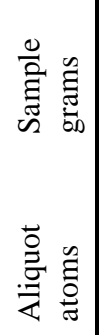 & 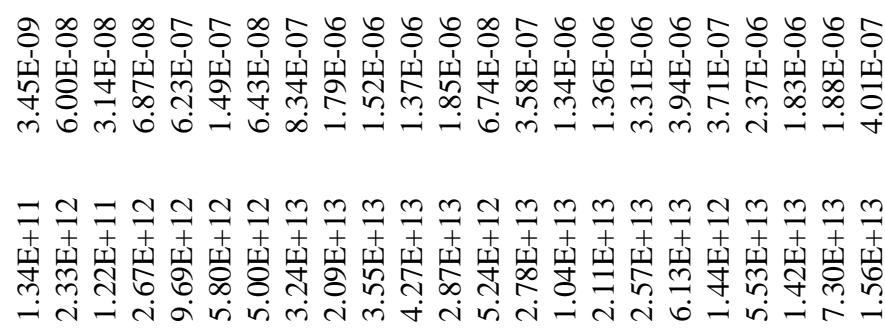 \\
\hline 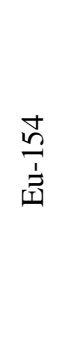 & 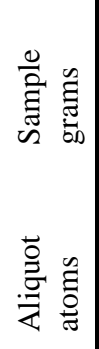 & 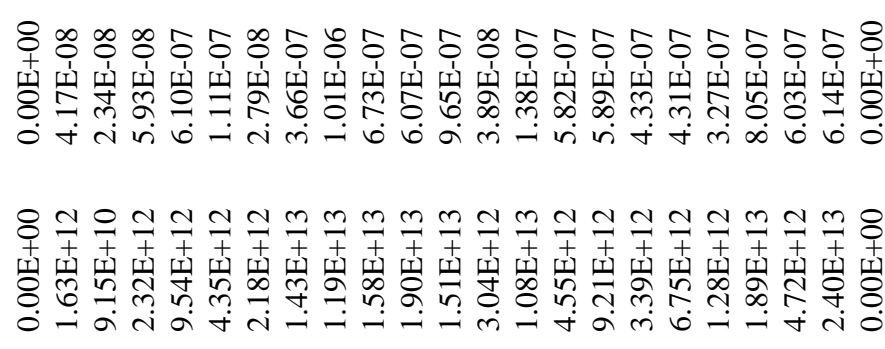 \\
\hline$\frac{\tilde{n}}{\frac{1}{1}}$ & 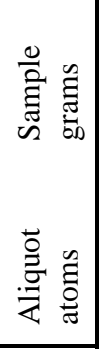 & 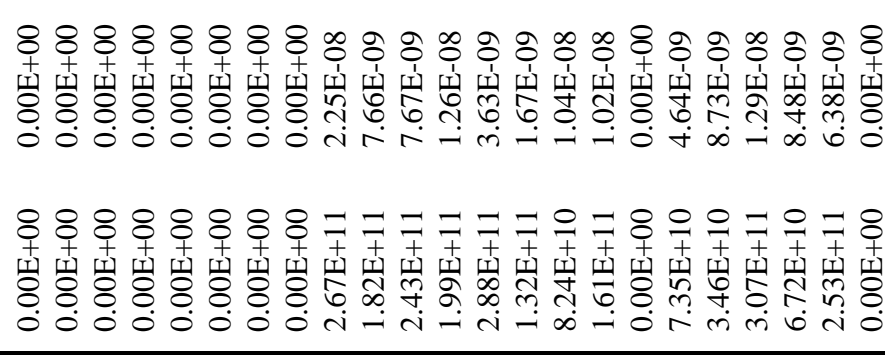 \\
\hline$\frac{⿱}{\dot{d}}$ & 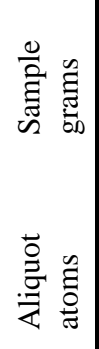 & 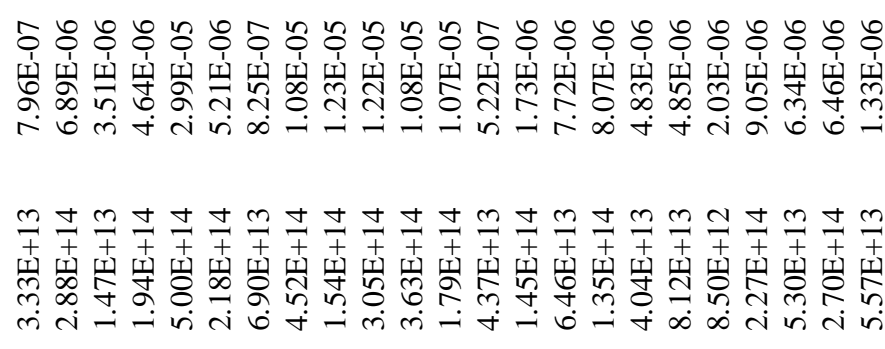 \\
\hline & $\stackrel{\vec{\Xi}}{\stackrel{\Xi}{\sharp}}$ & 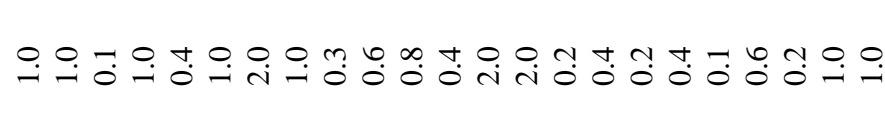 \\
\hline & 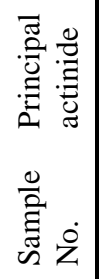 & 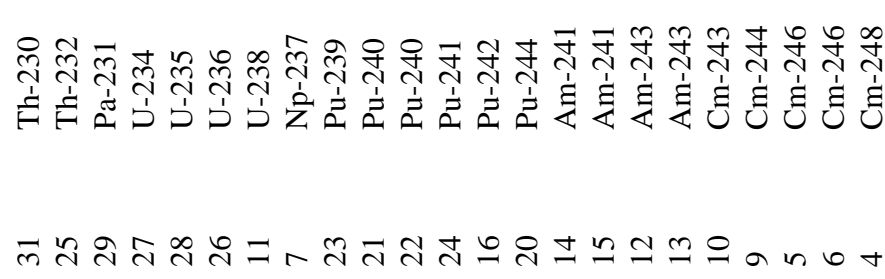 \\
\hline
\end{tabular}




\section{APPENDIX F}

\section{SUMMARY OF EXPERIMENTAL AND CALCULATED FISSION-PRODUCT VALUES FOR ACTINIDE SAMPLES}

The following table compares the measured and calculated values for the fission products in the case of each nondosimeter actinide sample that gave useable data. Measured and calculated values are in grams per sample and refer to the end-of-irradiation date. The measured values quoted here include the sample-loss adjustments described in Sect. 3 for four of the samples $\left({ }^{236} \mathrm{U},{ }^{238} \mathrm{U},{ }^{239} \mathrm{Pu}\right.$, and $\left.{ }^{242} \mathrm{Pu}\right)$. 
Table F.1. Comparison of measured and calculated values for fission products (measured and calculated amounts are grams in sample)

\begin{tabular}{|c|c|c|c|c|c|c|c|c|c|}
\hline \multirow{2}{*}{$\begin{array}{l}\text { Fission } \\
\text { product }\end{array}$} & \multicolumn{3}{|c|}{ Th-230/Cap. \#31 } & \multicolumn{3}{|c|}{ Th-232/Cap. \#25 } & \multicolumn{3}{|c|}{$\mathrm{Pa}-231 / \mathrm{Cap} . \# 29$} \\
\hline & Measured & Calculated & $\mathrm{E} / \mathrm{C}$ & Measured & Calculated & $\mathrm{E} / \mathrm{C}$ & Measured & Calculated & $\mathrm{E} / \mathrm{C}$ \\
\hline Ru-106 & & & & $4.96 \mathrm{E}-8$ & $3.66 \mathrm{E}-7$ & 0.14 & $5.93 \mathrm{E}-8$ & $1.04 \mathrm{E}-7$ & 0.57 \\
\hline \multicolumn{10}{|l|}{$\mathrm{Ag}-110 \mathrm{~m}$} \\
\hline $\mathrm{Sb}-125$ & $1.74 \mathrm{E}-8$ & $1.22 \mathrm{E}-8$ & 1.43 & $2.61 \mathrm{E}-7$ & $2.61 \mathrm{E}-7$ & 1.00 & $1.50 \mathrm{E}-7$ & $2.35 \mathrm{E}-7$ & 0.64 \\
\hline Cs-134 & $5.30 \mathrm{E}-8$ & $3.05 \mathrm{E}-8$ & 1.74 & $5.21 \mathrm{E}-7$ & $4.76 \mathrm{E}-7$ & 1.09 & $2.98 \mathrm{E}-7$ & $4.16 \mathrm{E}-7$ & 0.72 \\
\hline Cs-137 & $1.94 \mathrm{E}-6$ & $1.31 \mathrm{E}-6$ & 1.48 & $1.81 \mathrm{E}-5$ & $1.79 \mathrm{E}-5$ & 1.01 & $1.09 \mathrm{E}-5$ & $1.69 \mathrm{E}-5$ & 0.64 \\
\hline Ce-144 & $7.96 \mathrm{E}-7$ & $6.11 \mathrm{E}-7$ & 1.30 & $6.89 \mathrm{E}-6$ & $6.85 \mathrm{E}-6$ & 1.01 & $3.51 \mathrm{E}-6$ & $4.76 \mathrm{E}-6$ & 0.74 \\
\hline \multicolumn{10}{|l|}{ Eu-152 } \\
\hline Eu-154 & & & & 4.17E-8 & $5.05 \mathrm{E}-8$ & 0.83 & $2.34 \mathrm{E}-8$ & $6.68 \mathrm{E}-8$ & 0.35 \\
\hline Eu-155 & $3.45 \mathrm{E}-9$ & $5.50 \mathrm{E}-9$ & 0.63 & $6.00 \mathrm{E}-8$ & $7.92 \mathrm{E}-8$ & 0.76 & $3.14 \mathrm{E}-8$ & $1.64 \mathrm{E}-7$ & 0.19 \\
\hline
\end{tabular}

Fission product
U-234/ Cap. \#27

Measured Calculated E/C
U-235/ Cap. \#28

Measured Calculated E/C
U-236/ Cap. \#26

Measured Calculated E/C (measured value adjusted)

$\begin{array}{llllllllll}\text { Ru-106 } & 2.50 \mathrm{E}-7 & 3.36 \mathrm{E}-7 & 0.74 & 1.14 \mathrm{E}-6 & 2.70 \mathrm{E}-6 & 0.42 & 1.13 \mathrm{E}-6 & 1.25 \mathrm{E}-6 & 0.90 \\ \text { Ag-110m } & & & & & & & & & \\ \text { Sb-125 } & 1.03 \mathrm{E}-7 & 1.58 \mathrm{E}-7 & 0.65 & 3.38 \mathrm{E}-7 & 5.38 \mathrm{E}-7 & 0.63 & 1.73 \mathrm{E}-7 & 2.11 \mathrm{E}-7 & 0.82 \\ \text { Cs-134 } & 5.41 \mathrm{E}-7 & 4.61 \mathrm{E}-7 & 1.17 & 2.22 \mathrm{E}-6 & 4.35 \mathrm{E}-6 & 0.51 & 1.42 \mathrm{E}-6 & 8.36 \mathrm{E}-7 & 1.70 \\ \text { Cs-137 } & 1.33 \mathrm{E}-5 & 1.15 \mathrm{E}-5 & 1.16 & 5.24 \mathrm{E}-5 & 9.84 \mathrm{E}-5 & 0.53 & 3.00 \mathrm{E}-5 & 1.95 \mathrm{E}-5 & 1.54 \\ \text { Ce-144 } & 4.64 \mathrm{E}-6 & 4.58 \mathrm{E}-6 & 1.01 & 2.99 \mathrm{E}-5 & 2.99 \mathrm{E}-5 & 1.00 & 1.02 \mathrm{E}-5 & 6.30 \mathrm{E}-6 & 1.62 \\ \text { Eu-152 } & & & & & & & & & \\ \text { Eu-154 } & 5.93 \mathrm{E}-8 & 6.32 \mathrm{E}-8 & 0.94 & 6.10 \mathrm{E}-7 & 6.39 \mathrm{E}-7 & 0.95 & 2.18 \mathrm{E}-7 & 1.59 \mathrm{E}-7 & 1.37 \\ \text { Eu-155 } & 6.87 \mathrm{E}-8 & 8.27 \mathrm{E}-8 & 0.83 & 6.23 \mathrm{E}-7 & 6.00 \mathrm{E}-7 & 1.04 & 2.92 \mathrm{E}-7 & 2.17 \mathrm{E}-7 & 1.35\end{array}$

Fission product
Np-237/Cap. \#7 Measured Calculated E/C
U-238 /Cap. \#11

Measured Calculated E/C (measured value adjusted)
Pu-239 /Cap. \# 23

Measured Calculated E/C (measured value adjusted)

$\begin{array}{llllllllll}\text { Ru-106 } & 9.33 \mathrm{E}-7 & 7.94 \mathrm{E}-6 & 0.12 & 2.03 \mathrm{E}-6 & 1.97 \mathrm{E}-6 & 1.03 & 2.70 \mathrm{E}-6 & 2.23 \mathrm{E}-5 & 0.12 \\ \text { Ag-110m } & 4.89 \mathrm{E}-9 & 2.90 \mathrm{E}-9 & 1.69 & 2.47 \mathrm{E}-9 & 6.70 \mathrm{E}-10 & 3.70 & 3.78 \mathrm{E}-8 & 1.64 \mathrm{E}-8 & 2.30 \\ \text { Sb-125 } & 6.00 \mathrm{E}-7 & 5.98 \mathrm{E}-7 & 1.00 & 1.80 \mathrm{E}-7 & 8.90 \mathrm{E}-8 & 2.02 & 9.92 \mathrm{E}-7 & 1.32 \mathrm{E}-6 & 0.75 \\ \text { Cs-134 } & 1.55 \mathrm{E}-6 & 1.41 \mathrm{E}-6 & 1.10 & 4.71 \mathrm{E}-7 & 2.76 \mathrm{E}-7 & 1.71 & 5.92 \mathrm{E}-6 & 4.87 \mathrm{E}-6 & 1.22 \\ \text { Cs-137 } & 4.03 \mathrm{E}-5 & 4.24 \mathrm{E}-5 & 0.95 & 1.26 \mathrm{E}-5 & 8.04 \mathrm{E}-6 & 1.57 & 1.17 \mathrm{E}-4 & 1.05 \mathrm{E}-4 & 1.11 \\ \text { Ce-144 } & 1.08 \mathrm{E}-5 & 1.21 \mathrm{E}-5 & 0.89 & 3.96 \mathrm{E}-6 & 2.53 \mathrm{E}-6 & 1.57 & 1.70 \mathrm{E}-5 & 2.15 \mathrm{E}-5 & 0.79 \\ \text { Eu-152 } & & & & & & & 3.10 \mathrm{E}-8 & 2.93 \mathrm{E}-8 & 1.06 \\ \text { Eu-154 } & 3.66 \mathrm{E}-7 & 5.17 \mathrm{E}-7 & 0.71 & 1.34 \mathrm{E}-7 & 9.75 \mathrm{E}-8 & 1.37 & 1.39 \mathrm{E}-6 & 1.70 \mathrm{E}-6 & 0.82 \\ \text { Eu-155 } & 8.34 \mathrm{E}-7 & 1.02 \mathrm{E}-6 & 0.82 & 3.09 \mathrm{E}-7 & 2.05 \mathrm{E}-7 & 1.51 & 2.47 \mathrm{E}-6 & 2.75 \mathrm{E}-6 & 0.90\end{array}$


Table F.1 (continued)

Fission $\quad$ Pu-240/ Cap. \#21

product Measured Calculated E/C

Pu-240/Cap. \#22

Measured Calculated E/C

\begin{tabular}{llll}
\hline & & & \\
Ru-106 & $7.95 \mathrm{E}-7$ & $1.36 \mathrm{E}-5$ & 0.06 \\
Ag-110m & $2.27 \mathrm{E}-8$ & $7.63 \mathrm{E}-9$ & 2.98 \\
Sb-125 & $3.77 \mathrm{E}-7$ & $6.85 \mathrm{E}-7$ & 0.55 \\
Cs-134 & $1.80 \mathrm{E}-6$ & $1.78 \mathrm{E}-6$ & 1.01 \\
Cs-137 & $4.32 \mathrm{E}-5$ & $4.37 \mathrm{E}-5$ & 0.99 \\
Ce-144 & $1.22 \mathrm{E}-5$ & $1.16 \mathrm{E}-5$ & 1.05 \\
Eu-152 & $7.66 \mathrm{E}-9$ & $1.09 \mathrm{E}-8$ & 0.70 \\
Eu-154 & $6.73 \mathrm{E}-7$ & $7.91 \mathrm{E}-7$ & 0.85 \\
Eu-155 & $1.52 \mathrm{E}-6$ & $1.56 \mathrm{E}-6$ & 0.97
\end{tabular}

1.20E-6 1.37E-5 0.09

$2.17 \mathrm{E}-8 \quad 7.68 \mathrm{E}-9 \quad 2.83$

3.63E-7 $\quad 6.87 \mathrm{E}-7 \quad 0.53$

$1.79 \mathrm{E}-6 \quad 1.79 \mathrm{E}-6 \quad 1.00$

$\begin{array}{lll}4.24 \mathrm{E}-5 & 4.38 \mathrm{E}-5 & 0.97\end{array}$

$1.08 \mathrm{E}-5 \quad 1.16 \mathrm{E}-5 \quad 0.93$

7.67E-9 $\quad 1.09 \mathrm{E}-8 \quad 0.70$

$\begin{array}{lll}6.07 \mathrm{E}-7 & 7.95 \mathrm{E}-7 & 0.76\end{array}$

$1.37 \mathrm{E}-6 \quad 1.56 \mathrm{E}-6 \quad 0.88$

Fission $\quad$ Pu-241/Cap. \#24

product
Measured Calculated
Pu-242/Cap. \#16

Measured Calculated E/C (measured value adjusted)
$\mathrm{Pu}-244 / \mathrm{Cap} . \# 20$

Measured Calculated E/C

\begin{tabular}{llllllllll}
\hline & & & & & & & & & \\
Ru-106 & $4.23 \mathrm{E}-6$ & $1.77 \mathrm{E}-5$ & 0.24 & $3.54 \mathrm{E}-7$ & $1.41 \mathrm{E}-6$ & 0.25 & $4.44 \mathrm{E}-7$ & $1.86 \mathrm{E}-6$ & 0.24 \\
Ag-110m & $3.38 \mathrm{E}-8$ & $1.55 \mathrm{E}-8$ & 2.18 & $3.41 \mathrm{E}-9$ & $1.39 \mathrm{E}-9$ & 2.45 & $7.07 \mathrm{E}-9$ & $1.83 \mathrm{E}-9$ & 3.86 \\
Sb-125 & $3.56 \mathrm{E}-7$ & $8.70 \mathrm{E}-7$ & 0.41 & $2.89 \mathrm{E}-8$ & $5.96 \mathrm{E}-8$ & 0.48 & $3.73 \mathrm{E}-8$ & $7.26 \mathrm{E}-8$ & 0.51 \\
Cs-134 & $2.25 \mathrm{E}-6$ & $2.72 \mathrm{E}-6$ & 0.83 & $1.69 \mathrm{E}-7$ & $1.84 \mathrm{E}-7$ & 0.92 & $2.08 \mathrm{E}-7$ & $2.22 \mathrm{E}-7$ & 0.94 \\
Cs-137 & $4.72 \mathrm{E}-5$ & $6.17 \mathrm{E}-5$ & 0.76 & $4.08 \mathrm{E}-6$ & $4.71 \mathrm{E}-6$ & 0.87 & $5.63 \mathrm{E}-6$ & $5.79 \mathrm{E}-6$ & 0.97 \\
Ce-144 & $1.07 \mathrm{E}-5$ & $1.38 \mathrm{E}-5$ & 0.78 & $1.30 \mathrm{E}-6$ & $1.28 \mathrm{E}-6$ & 1.02 & $1.73 \mathrm{E}-6$ & $1.68 \mathrm{E}-6$ & 1.03 \\
Eu-152 & $1.26 \mathrm{E}-8$ & $2.17 \mathrm{E}-8$ & 0.58 & $9.04 \mathrm{E}-9$ & $1.41 \mathrm{E}-9$ & 6.41 & $1.67 \mathrm{E}-9$ & $1.66 \mathrm{E}-9$ & 1.01 \\
Eu-154 & $9.65 \mathrm{E}-7$ & $1.34 \mathrm{E}-6$ & 0.72 & $9.69 \mathrm{E}-8$ & $9.93 \mathrm{E}-8$ & 0.98 & $1.38 \mathrm{E}-7$ & $1.40 \mathrm{E}-7$ & 0.99 \\
Eu-155 & $1.85 \mathrm{E}-6$ & $2.51 \mathrm{E}-6$ & 0.74 & $1.68 \mathrm{E}-7$ & $2.04 \mathrm{E}-7$ & 0.82 & $3.58 \mathrm{E}-7$ & $3.08 \mathrm{E}-7$ & 1.16
\end{tabular}

Fission Am-241/Cap. \#14

product Measured Calculated E/C
Am-241 /Cap. \#15

Measured Calculated E/C

\begin{tabular}{llll}
\hline & & & \\
Ru-106 & $2.55 \mathrm{E}-6$ & $9.60 \mathrm{E}-6$ & 0.27 \\
Ag-110m & $1.34 \mathrm{E}-8$ & $9.29 \mathrm{E}-9$ & 1.44 \\
Sb-125 & $6.71 \mathrm{E}-7$ & $5.66 \mathrm{E}-7$ & 1.19 \\
Cs-134 & $1.09 \mathrm{E}-6$ & $1.14 \mathrm{E}-6$ & 0.96 \\
Cs-137 & $2.97 \mathrm{E}-5$ & $3.20 \mathrm{E}-5$ & 0.93 \\
Ce-144 & $7.72 \mathrm{E}-6$ & $8.79 \mathrm{E}-6$ & 0.88 \\
Eu-152 & $1.04 \mathrm{E}-8$ & $8.44 \mathrm{E}-9$ & 1.23 \\
Eu-154 & $5.82 \mathrm{E}-7$ & $6.52 \mathrm{E}-7$ & 0.89 \\
Eu-155 & $1.34 \mathrm{E}-6$ & $1.60 \mathrm{E}-6$ & 0.84
\end{tabular}

$\begin{array}{lll}5.02 \mathrm{E}-6 & 9.78 \mathrm{E}-6 & 0.51 \\ 1.78 \mathrm{E}-8 & 9.52 \mathrm{E}-9 & 1.87 \\ 7.00 \mathrm{E}-7 & 5.77 \mathrm{E}-7 & 1.21 \\ 1.12 \mathrm{E}-6 & 1.17 \mathrm{E}-6 & 0.96 \\ 2.97 \mathrm{E}-5 & 3.26 \mathrm{E}-5 & 0.91 \\ 8.07 \mathrm{E}-6 & 8.96 \mathrm{E}-6 & 0.90 \\ 1.02 \mathrm{E}-8 & 8.62 \mathrm{E}-9 & 1.18 \\ 5.89 \mathrm{E}-7 & 6.67 \mathrm{E}-7 & 0.88 \\ 1.36 \mathrm{E}-6 & 1.63 \mathrm{E}-6 & 0.83\end{array}$


Table F.1 (continued)

\begin{tabular}{|c|c|c|c|c|c|c|c|c|c|}
\hline \multirow{2}{*}{$\begin{array}{l}\text { Fission } \\
\text { product }\end{array}$} & \multicolumn{2}{|c|}{ Am-243/Cap. \#12 } & \multirow[b]{2}{*}{$\mathrm{E} / \mathrm{C}$} & & & & \multicolumn{2}{|c|}{ Am-243/Cap. \#13 } & \multirow[b]{2}{*}{$\mathrm{E} / \mathrm{C}$} \\
\hline & Measured & Calculated & & & & & Measured & Calculated & \\
\hline $\mathrm{Ru}-106$ & $1.81 \mathrm{E}-6$ & 7.35E-6 & 0.25 & & & & $1.81 \mathrm{E}-6$ & $7.41 \mathrm{E}-6$ & 0.24 \\
\hline Ag-110m & $1.42 \mathrm{E}-8$ & $9.86 \mathrm{E}-9$ & 1.44 & & & & $1.83 \mathrm{E}-8$ & $1.00 \mathrm{E}-8$ & 1.83 \\
\hline $\mathrm{Sb}-125$ & $2.94 \mathrm{E}-7$ & $3.40 \mathrm{E}-7$ & 0.86 & & & & $2.92 \mathrm{E}-7$ & $3.43 \mathrm{E}-7$ & 0.85 \\
\hline Cs-134 & $5.78 \mathrm{E}-7$ & $7.01 \mathrm{E}-7$ & 0.82 & & & & $5.78 \mathrm{E}-7$ & $7.13 \mathrm{E}-7$ & 0.81 \\
\hline Cs-137 & $1.68 \mathrm{E}-5$ & $2.41 \mathrm{E}-5$ & 0.70 & & & & $1.67 \mathrm{E}-5$ & $2.43 \mathrm{E}-5$ & 0.69 \\
\hline Ce-144 & $4.83 \mathrm{E}-6$ & $6.33 \mathrm{E}-6$ & 0.76 & & & & $4.85 \mathrm{E}-6$ & $6.38 \mathrm{E}-6$ & 0.76 \\
\hline Eu-152 & & & & & & & 4.64E-9 & $6.38 \mathrm{E}-9$ & 0.73 \\
\hline Eu-154 & $4.33 \mathrm{E}-7$ & $4.71 \mathrm{E}-7$ & 0.92 & & & & $4.31 \mathrm{E}-7$ & 4.79E-7 & 0.90 \\
\hline Eu-155 & $3.31 \mathrm{E}-6$ & $1.09 \mathrm{E}-6$ & 3.04 & & & & $3.94 \mathrm{E}-6$ & $1.10 \mathrm{E}-6$ & 3.58 \\
\hline \multirow{2}{*}{$\begin{array}{l}\text { Fission } \\
\text { product }\end{array}$} & \multicolumn{2}{|c|}{ Cm-243/Cap. \#10 } & & & & & \multicolumn{2}{|c|}{ Cm-244/Cap. \#9 } & \\
\hline & Measured & Calculated & $\mathrm{E} / \mathrm{C}$ & & & & Measured & Calculated & $\mathrm{E} / \mathrm{C}$ \\
\hline $\mathrm{Ru}-106$ & $9.19 \mathrm{E}-7$ & $2.19 \mathrm{E}-6$ & 0.42 & & & & $1.01 \mathrm{E}-5$ & $1.33 \mathrm{E}-5$ & 0.76 \\
\hline Ag-110m & $1.16 \mathrm{E}-8$ & $3.21 \mathrm{E}-9$ & 3.61 & & & & $3.59 \mathrm{E}-8$ & $1.50 \mathrm{E}-8$ & 2.39 \\
\hline $\mathrm{Sb}-125$ & $1.76 \mathrm{E}-7$ & $1.36 \mathrm{E}-7$ & 1.29 & & & & 4.60E-7 & $5.98 \mathrm{E}-7$ & 0.77 \\
\hline Cs-134 & $3.87 \mathrm{E}-7$ & $2.55 \mathrm{E}-7$ & 1.52 & & & & $1.11 \mathrm{E}-6$ & $1.08 \mathrm{E}-6$ & 1.03 \\
\hline Cs-137 & $9.39 \mathrm{E}-6$ & $7.88 \mathrm{E}-6$ & 1.19 & & & & $3.23 \mathrm{E}-5$ & $4.00 \mathrm{E}-5$ & 0.81 \\
\hline Ce-144 & $2.03 \mathrm{E}-6$ & $1.66 \mathrm{E}-6$ & 1.22 & & & & $9.05 \mathrm{E}-6$ & $1.12 \mathrm{E}-5$ & 0.81 \\
\hline Eu-152 & 8.73E-9 & $3.53 \mathrm{E}-9$ & 2.47 & & & & $1.29 \mathrm{E}-8$ & $1.47 \mathrm{E}-8$ & 0.88 \\
\hline Eu-154 & $3.27 \mathrm{E}-7$ & $2.24 \mathrm{E}-7$ & 1.46 & & & & $8.05 \mathrm{E}-7$ & $1.18 \mathrm{E}-6$ & 0.68 \\
\hline Eu-155 & $3.71 \mathrm{E}-7$ & $4.18 \mathrm{E}-7$ & 0.89 & & & & $2.37 \mathrm{E}-6$ & $2.72 \mathrm{E}-6$ & 0.87 \\
\hline \multirow{2}{*}{$\begin{array}{l}\text { Fission } \\
\text { product }\end{array}$} & \multicolumn{2}{|c|}{ Cm-246/Cap. \#5 } & \multirow{2}{*}{$\mathrm{E} / \mathrm{C}$} & \multirow{2}{*}{\multicolumn{2}{|c|}{$\begin{array}{r}\text { Cm-246/Cap. \#6 } \\
\text { Measured Calculated }\end{array}$}} & \multirow[b]{2}{*}{$\mathrm{E} / \mathrm{C}$} & \multirow{2}{*}{\multicolumn{2}{|c|}{$\begin{array}{c}\text { Cm-248/Cap. \#4 } \\
\text { Measured Calculated }\end{array}$}} & \\
\hline & Measured & Calculated & & & & & & & $\mathrm{E} / \mathrm{C}$ \\
\hline $\mathrm{Ru}-106$ & $6.99 \mathrm{E}-6$ & $1.02 \mathrm{E}-5$ & 0.69 & $3.80 \mathrm{E}-6$ & $1.05 \mathrm{E}-5$ & 0.36 & $1.03 \mathrm{E}-6$ & $1.75 \mathrm{E}-6$ & 0.59 \\
\hline $\mathrm{Ag}-110 \mathrm{~m}$ & $2.83 \mathrm{E}-8$ & $1.43 \mathrm{E}-8$ & 1.98 & $1.34 \mathrm{E}-8$ & $1.49 \mathrm{E}-8$ & 0.90 & $6.21 \mathrm{E}-9$ & $2.90 \mathrm{E}-9$ & 2.14 \\
\hline Sb-125 & $2.44 \mathrm{E}-7$ & $3.53 \mathrm{E}-7$ & 0.69 & $2.45 \mathrm{E}-7$ & $3.62 \mathrm{E}-7$ & 0.68 & $4.28 \mathrm{E}-8$ & $5.57 \mathrm{E}-8$ & 0.77 \\
\hline Cs-134 & $6.49 \mathrm{E}-7$ & $5.88 \mathrm{E}-7$ & 1.10 & $6.59 \mathrm{E}-7$ & $6.10 \mathrm{E}-7$ & 1.08 & $1.23 \mathrm{E}-7$ & $7.94 \mathrm{E}-8$ & 1.55 \\
\hline Cs-137 & $2.00 \mathrm{E}-5$ & $2.82 \mathrm{E}-5$ & 0.71 & $2.00 \mathrm{E}-5$ & $2.90 \mathrm{E}-5$ & 0.69 & $3.73 \mathrm{E}-6$ & $4.58 \mathrm{E}-6$ & 0.81 \\
\hline Ce-144 & $6.34 \mathrm{E}-6$ & $8.52 \mathrm{E}-6$ & 0.74 & $6.46 \mathrm{E}-6$ & $8.76 \mathrm{E}-6$ & 0.74 & $1.33 \mathrm{E}-6$ & $1.53 \mathrm{E}-6$ & 0.87 \\
\hline Eu-152 & $8.48 \mathrm{E}-9$ & $1.25 \mathrm{E}-8$ & 0.68 & $6.38 \mathrm{E}-9$ & $1.29 \mathrm{E}-8$ & 0.49 & & & \\
\hline Eu-154 & $6.03 \mathrm{E}-7$ & $9.25 \mathrm{E}-7$ & 0.65 & $6.14 \mathrm{E}-7$ & $9.58 \mathrm{E}-7$ & 0.64 & & & \\
\hline Eu-155 & $1.83 \mathrm{E}-6$ & $2.33 \mathrm{E}-6$ & 0.79 & $1.88 \mathrm{E}-6$ & $2.39 \mathrm{E}-6$ & 0.79 & $4.01 \mathrm{E}-7$ & $4.26 \mathrm{E}-7$ & 0.94 \\
\hline
\end{tabular}


ORNL-6889

\section{INTERNAL DISTRIBUTION}

1. J. B. Ball

2. S. J. Ball

3. F. E. Bertrand

4. J. E. Bigelow

5. B. L. Broadhead

6. J. K. Dickens

7. R. J. Hydzik

8. J. M. Keller

9. M. A. Kuliasha

10. D. C. Larson

11. L. C. Leal

12-16. B. D. Murphy

17-21. L. F. N orris

22. C. E. Oliver

23-27. C. V. Parks
28. L. M. Petrie

29. R. T. Primm, III

30-34. S. Raman

35. R. W. Roussin

36. J. C. Stewart

37-41. J. K. Thacker

42. R. L. Walker

43-47. R. M. Westfall

48. R. Q. Wright

49-50. Laboratory Records Dept.

51. Laboratory Records, ORNL-RC

52. Y-12 Technical Library

53. Central Research Library, Document Reference Section

54. ORNL Patent Section

\section{EXTERNAL DISTRIBUTION}

55-56. C. C. Foreman, Dounreay Nuclear Power Development Establishment, Thurso, Caithness, Scotland, United Kingdom

57-58. W. S. Fraser, Dounreay Nuclear Power Development Establishment, Thurso, Caithness, Scotland, United Kingdom

59-60. Philip B. Hemmig, Advanced Reactor Technology, U.S. Department of Energy, NE-542/GTN, Washington, DC 20585

61-65. T. Mukaiyama, Fast Critical Assembly, Japan Atomic Energy Research Institute, Tokai-mura, Naka-gun, Ibaraki-ken, Japan

66-70. T. D. Newton, Reactor Physics, Shielding, and Criticality Department, AEA Technology, B20 Winfrith, Dorchester, Dorset, United Kingdom DT2 8DH

71. J. A. Reafsnyder, Deputy Assistant Manager, Energy Research and Development, Department of Energy, Oak Ridge Operations, Post Office Box 2008, Oak Ridge, Tennessee 37831-6269

72. Office of Assistant Manager for Energy Research and Development, DOE Field Office, Oak Ridge, Tennessee 37831

73-133. For distribution as shown in TID-4500, distribution Category US-534 -- LMFBR Physics; Base Technology 